$N P \ldots 24300$

RE-ORDER No. $75-27$

\title{
A STUDY OF GEOTHERMAL PROSPECTS \\ IN THE WESTERN UNITED STATES
}

Final Report No. 28455-6001-RU-00

20 August 1975

Contract No. 954243

This work was performed for the Jet Propulsion Laboratory, California Institute of Technology, sponsored by the National Aeronautics and Space Administration under Contract NAS7-100.

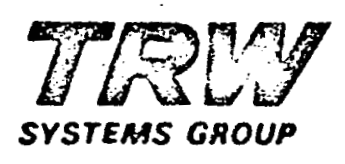

One Space Park, Redondo Beach, California 90278 


\section{DISCLAIMER}

This report was prepared as an account of work sponsored by an agency of the United States Government. Neither the United States Government nor any agency Thereof, nor any of their employees, makes any warranty, express or implied, or assumes any legal liability or responsibility for the accuracy, completeness, or usefulness of any information, apparatus, product, or process disclosed, or represents that its use would not infringe privately owned rights. Reference herein to any specific commercial product, process, or service by trade name, trademark, manufacturer, or otherwise does not necessarily constitute or imply its endorsement, recommendation, or favoring by the United States Government or any agency thereof. The views and opinions of authors expressed herein do not necessarily state or reflect those of the United States Government or any agency thereof. 


\section{DISCLAIMER}

Portions of this document may be illegible in electronic image products. Images are produced from the best available original document. 
This report contains information prepared by TRW Systems Group, TRW, Inc., under JPL subcontract. Its content is not necessarily endorsed by the Jet Propulsion Laboratory, California Institute of Technology, or the National Aeronautics and Space Administration. 


\section{NEW TECHNOLOGY}

No items of new technology have been identified in this study. 


\section{ABSTRACT.}

The commercial development potential of 13 underdeveloped geothermal prospects in the Western United States has been examined and the prospects have been ranked in order of relative potential for development on the basis of investment considerations. The following were considered in the ranking: geotechnical and engineering data, energy market accessibility, administrative constraints, and environmental and socio-economic factors.

The primary ranking criterion is the unit cost of energy production expected from each prospect. This criterion is obtained principally from expected reservoir temperatures and depths. Secondary criteria are administrative constraints, environmental factors and the quality of the geotechnical data.

The Roosevelt, Utah, prospect ranks first in development potential followed in order by Beowawe, Nevada; Coso Hot Springs, California; Long Valley; California; and Brady's Hot Springs, Nevada. 


\section{TABLE OF CONTENTS}

1. INTRODUCTION AND SUMMARY

2. PROSPECT EVALUATION CRITERIA

$\underline{\text { Page }}$

3. GEOTECHNICAL EVALUATION

3.1 Geotechnical Data Types

3.1.1 Surface Data

3.1 .2 Geophysics

3.1.3 Subsurface Data

3.1.4 Geochemistry

3.1.5 Reservoir Characteristics

3.2 Cost Data

4. LOAD CENTER EVALUATION

4.1 Electrical Power Generation 21

4.2 Space/Process Heating . 24

5. EVALUATION OF ADMINISTRATIVE REGULATIONS 26

AND CONSTRAINTS

6. ENVIRONMENTAL AND SOCIO-ECONOMIC SETTINGS 32

AND EFFECTS

7. RANKING OF PROSPECTS

APPENDIX A: GEOTECHNICAL AND RESOURCE UTILIZATION

Al Geotechnical

A1.1 Regional Geology

A1.1.1 Acidic Volcanics

51

Al.2 Thermal Spring Distribution 52

Al.3 Geophysical Techniques Related to 54 Geothermal Exploration

A1.4 Geochemical Techniques Related to 55 Geothermal Exploration

A1.5 Geothermal Reservoir Characteristics 56

A2 Resource Utilization 
APPENDIX B: ADMINISTRATIVE REQUIREMENTS

Page

BI State or Private Lands

B1.1 Exploration 62

B1.2 Development and Production 64

B2. Federal Lands 64

B2.1 Exploration 65

B2.2 Development and Production 67

B3 Assessment by Developers 68

APPENDIX C: ENVIRONMENTAL AND SOCIO-ECONOMIC EFFECTS 70

Cl Background 70

C2 Environmental Effects $\quad 72$

C2.1 Plant Life $\quad 72$

C2.2 Wildlife 72

C2.3 Air Pollution $\quad 73$

C2.4 Water Pollution 73

C2.5 Noise 73

C2.6 Topography. $\quad 74$

C3 Socio-economic Effects $\quad 74$

C3.1 Employment 74

C3.2 Population Trends . 75

C3.3 Aesthetics 75

APPENDIX D: SPECIFIC PROSPECT DESCRIPTIONS 76

D1 Beowawe, Nevada 76

D2 Brady's Hot Springs, Nevada 82

D3 Brigham City, Utah $\quad 86$

D4 Chandler, Arizona 9

D5 Clear Lake, California 94

D6 Cosó Hot Springs, California. . $\quad 98$

D7 Fly Ranch/Gerlach, Nevada 102

D8 Long Valley, California 106

D9 Mountain Home, Idaho 110

D10 Raft River, Idaho 114

D11 Roosevelt, Utah 118

D12 Steamboat Springs, Nevada 122

D13 Surprise Valley, California 126 


\section{LIST OF FIGURES}

Page

1. Location of Prospects Included in Development Potential Ranking.

2. Major Ranking Criteria 7

3. Ranking Criteria - Expected Revenues 8

4. Ranking Criteria - Time to Market 9

5. Ranking Criteria - Whole-Field Costs 10

6. Ranking Criteria - Unit Cost of Energy 11

7. Areas of Geothermal Interest in the Western 13 United States

8. Cost of Completed Geothermal Well 18

9. Energy from Given Well Flow 20

10. Electrical Power Distribution Network 22

11. Prospect Temperatures and Depths-Lines of Equal 38 Well Costs per Installed KW

12. Legend for Figure 11 . 39

\section{APPENDICES}

A-1 Tectonic Features of the Western United States 48

A-2a Schematic Section - Basin and Range Province 49

$A-2 b$ Schematic Plan - California Shear-Faulted Province 49.

A-3 Thermal Spring Distribution in the Western 53 United States

B-1 Administrative Requirements for Development of 61 Geothermal Resources on State or Private Land in Cal ifornia

B-2 Administrative Requirements for Development of 66 Geothermal Resources on Federal Land

D1 Legend 77

D2 Beowawe - Lander/Eureka County, Nevada 81

D3 Brady's Hot Springs - Lyon/Churchill County, Nevada 85

D4 Brigham City - Box Elder County, Utah. 89 
Page

D5 Chandler - Maricopa County, Arizona 93

D6 Clear Lake - Lake County, California 97

D7 Coso Hot Springs - Inyo County, California 101

D8 Fly Ranch/Gerlach - Washoe/Pershing County, Nevada 105

D9 Long Valley - Mono County, California 109

B10 Mountain Home - Elmore County, Idaho 113

D11 Raft River - Cassia County, Idaho 117

D12 Roosevelt - Beaver County, Utah 121

D13 Steamboat Springs - Washoe County, Nevada 125

D14 Surprise Valley - Modoc County, California 129 


\section{LIST OF TABLES}

Page

1. Prospects by Development Potential Rank 4

2. Surface Geotechnical Data Summary 14

3. Subsurface Geotechnical Data Summary 15

4. User Proximity Data Summary 23

5. County Administrative requirements for 27 Development and Land Status of the Geothermal Prospects in California

6. Assessment of Prospects by Administrative 29 Requirements

7. Contribution of Federal Requirements to Severity Indices

8. Summary of Environmental and Socio-economic Effects

Notes to Table 8

9. Nominal Costs and Cost Differences 42

10. Prospect Pair Differences 44

APPENDICES

B-1 Administrative Requirements for Development of Geothermal Resources on State or Private Land

B-2 Administrative Requirement Assessment by Geothermal Resource Developers 


\section{INTRODUCTION AND SUMMARY}

An inportant insight into the requirements for geothermal development can be obtained by examining key factors affecting the development of a representative cross-section of known geothermal prospects. This report presents the results of a study sponsored by the Jet Propulsion Laboratory and done by TRW Systems Group, of the commercial development potential of a number of underdeveloped geothermal prospects in the western United States.

This study has resulted in the ranking of 13 genthermul prospects in order of relative potential for development, as seen from an investor's point of view, given current information. These prospects were selected as the most immediately promising out of the many geothermally-interesting areas in the western United States. These 13 prospects have been sites of active exploration efforts, including surface geophysics and, in most cases, deep exploratory wells. The prospect list does not include, however, any prospects where development has already reached the extensive production test stage or beyond, i.e., the Geysers, the Imperial Valley fields, and Baca Ranch, New Mexico. The locations of the 13 prospects are shown in Figure 1. They are widespread geographically, and represent a broad range of geologic environments.

The following has been used in determining the ranking of the prospects:

- Geotechnical and engineering data, including surface and subsurface geology, geophysics and geochemistry, reservoir characteristics, and the technology and costs of energy extraction and conversion.

- The accessibility of energy markets, i.e., electrical distribution systems, population, and users of space and process heat. 
R $0-75-27$.
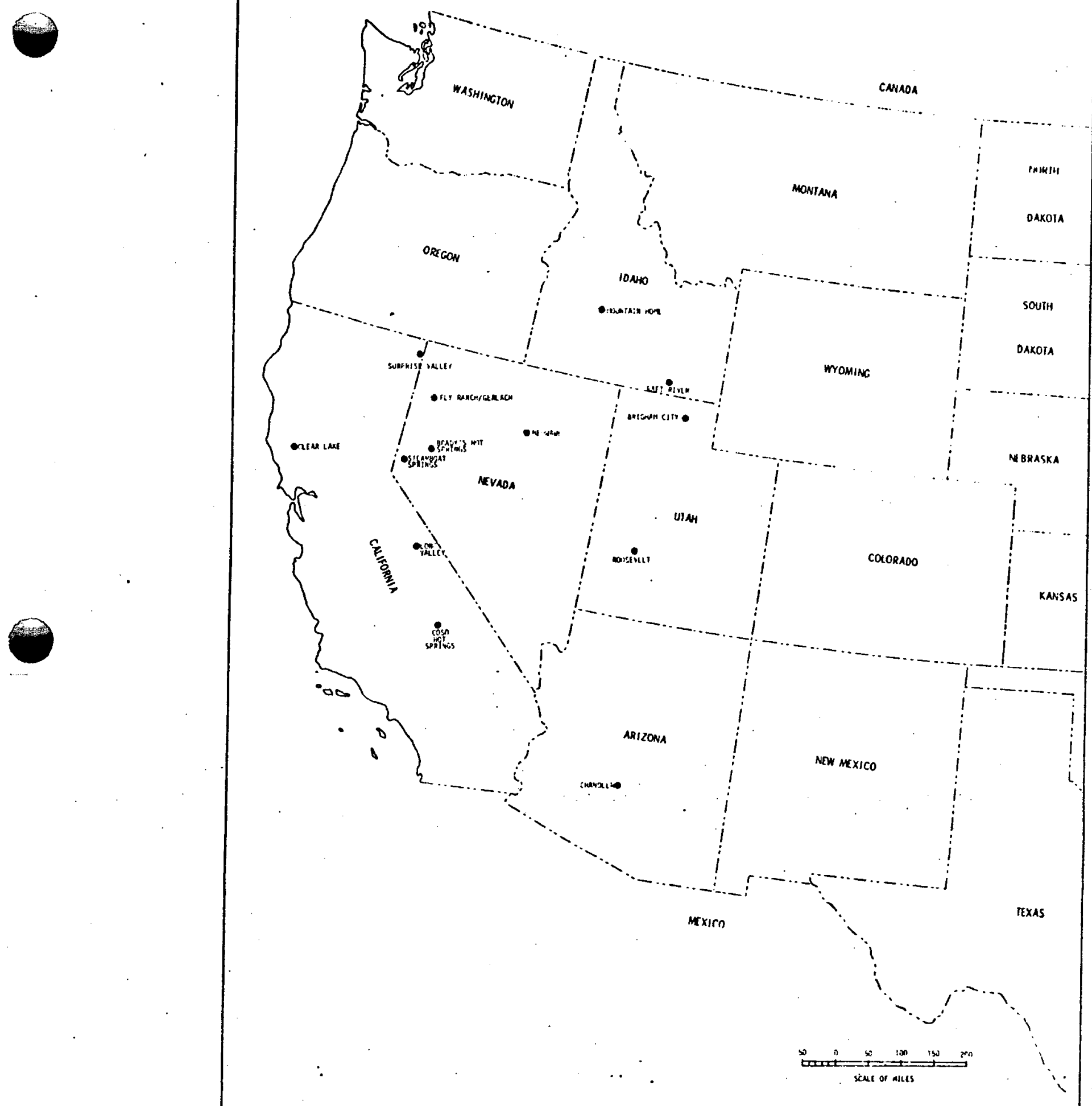

LOCATION OF PROSPECTS INCLUDED IN DEVELOPMENT POTENTIAL RANKING

FIGURE 1 
- Administrative reguiations and constraints

- Environmental factors.

These data have been combined to estimate the differences among prospects in expected return on investment. The similarities and differences among prospects are such that the primary ranking criterion is the expected unit cost of energy production, as estimated from geotechnical data (primarily subsurface temperatures and well depths).

The effect of other factors on the ranking has been to distinguish between pairs of prospects that rank approximately equally on the unitcost criterion alone, but not to reverse the order of any two pruspects that are clearly distinct in unit cost. The most important secondary differences among prospects are administrative constraints and delays, environmental settings, and the quality of available geotechnical information.

Table 1 lists the thirteen prospects in order of development . potential. This table also lists the likely reservoir temperatures and depths. 
TABLE 1 - PROSPECTS BY DEVELOPMENT POTENTIAL RANK (Tabulated in order of decreasing potential)

1. Roosevelt, Utah

2. Beowawe, Nevada

3. Coso Hot Springs, California

4. Long Valley, California

5. Brady's Hot Springs, Nevada

6. Steamboat Springs, Nevada

7. Clear Lake, California

8. Surprise Valley, California

9. Fly Ranch/Gerlach, Nevada

10. Mountain Home, Idaho

11. Raft River, Idaho

12. Brigham City, Utah

13. Chandler, Arizona

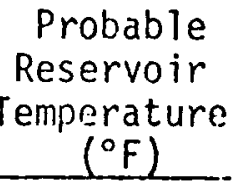

$\therefore 420$

410

$>300$

350

420

370

370

320

$>220$

380

300

285

350

\begin{tabular}{c} 
Probable \\
Reservoir \\
nepth \\
(freet) \\
\hline 7800 \\
$y 500$ \\
$>500$ \\
$>1000$ \\
5000 \\
$>2000$ \\
9000 \\
4500 \\
$>1000$ \\
10,000 \\
6000 \\
11,000 \\
10,000
\end{tabular}




\section{PROSPECT EVALUATION CRITERIA}

The overall criterion adopted for the evaluation of the prospects is the potential for commercial development, from the viewpoint of an investor seeking the best return on investments in geothermal projects. Comparing the expected net discounted cash flow for alternative projects is a common and useful aid in making investment choices. This process is used here as a framework and rationale for the ranking of prospects, but it will be evident that much of the relevant information is qualitative or uncertain, given the present state of information. Part of the overall ranking will depend on choices of investment strategy that will be determined by the character of investment, and investors, in geothermal energy.

Geothermal investment in unproven prospects, like investment in many other kinds of earth resources, is an arena of high risk and high returns. Major investors operate on the statistical probability that most prospects will not repay exploration costs, but that the high returns from a few successful developments will more than cover the losses. The major ingredients for continuing survival in earth-resources investment are skill in the use of exploration funds, and sufficient capital reserves to average out inevitable fluctuations in the success-ratio of exploration efforts. The aggregated behavior of independent minor investors with local ties or preferences will generally have the same overall effect as the actions of one or a few major investors.

The corresponding strategy appropriate to geothermal investment has two features important to the ranking process used here:

- A representative geathermal investor will spread exploration funds over several prospects. He will not generally commit to an investment in several successive phases of a single project, but will make continuing choices about where to spend limited sums in order to gain information that will guide the next decision. 
- Most geothermal investors are much more interested in large prospects of high potential than in modest or small-scale projects. Small successful developments are welcome byproducts of exploration, but are not an important goal of exploration efforts.

These strategic criteria are relevant to the potential of the prospects for attracting actual investment capital, and will serve to distinguish the rank of some prospects that are not clearly different in expected costs.

More formally, the expected net discounted cash flow resulting from investment in a project is the estimated present cash value of the ownership of the project. It is the net sum of all items of expenditure and income that may occur in the future course of the project, with each item discounted to its present cash value and multiplied by the probability that it will actually occur.

The main factors that enter into an accounting of expected net discounted cash flow for a geothermal project are depicted in Figures 2 through 6 , in the form of flow charts that indicate how and where different kinds of information enter the process and are combined to draw conclusions. Figures 3 through 6 show the flow of information into each of the four main headings of Figure 2.

The types of primary information that enter into the flow charts fall naturally into four categories: geotechnical and engineering, access to markets, administrative considerations, and environmental factors. The following four sections of this report summarize the most important primary information, with special emphasis on significant differences between prospects. In the last section, the ranking process is applied to the 13 prospects. 


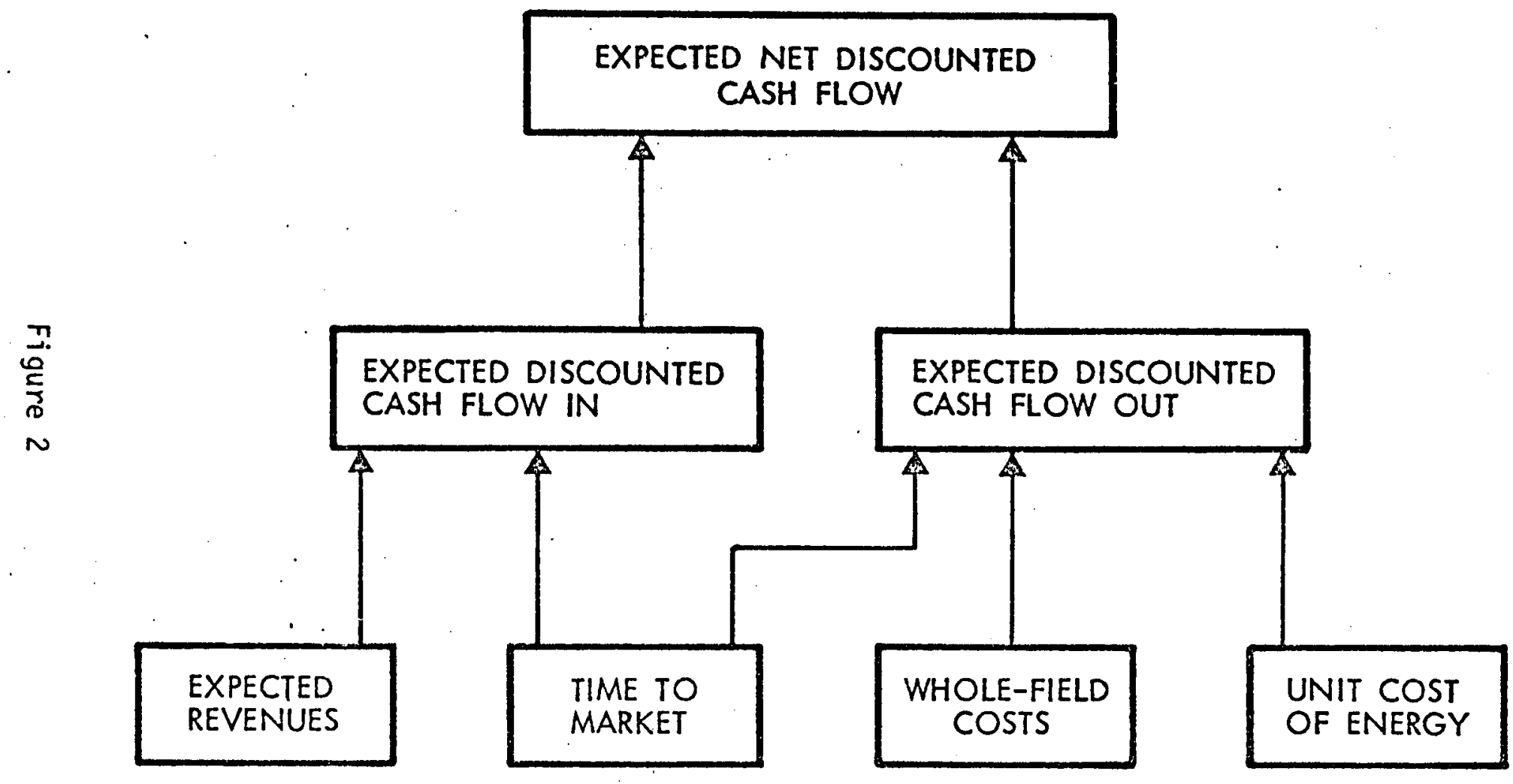

MAJOR RANKING CRITERIA 


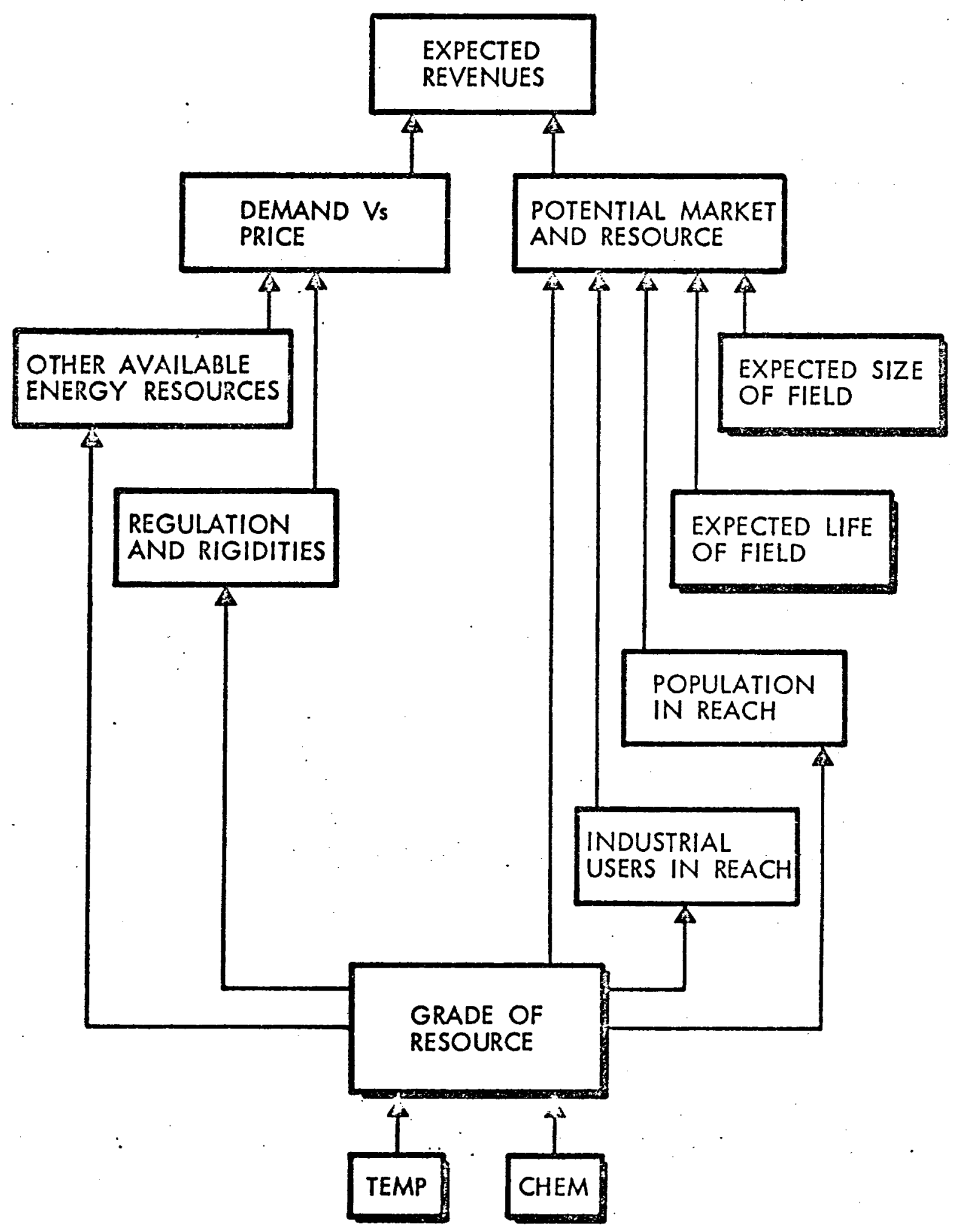

RANKING CRITERIA - EXPECTED REVENUES

Figure 3 


\section{R0 75-27.}

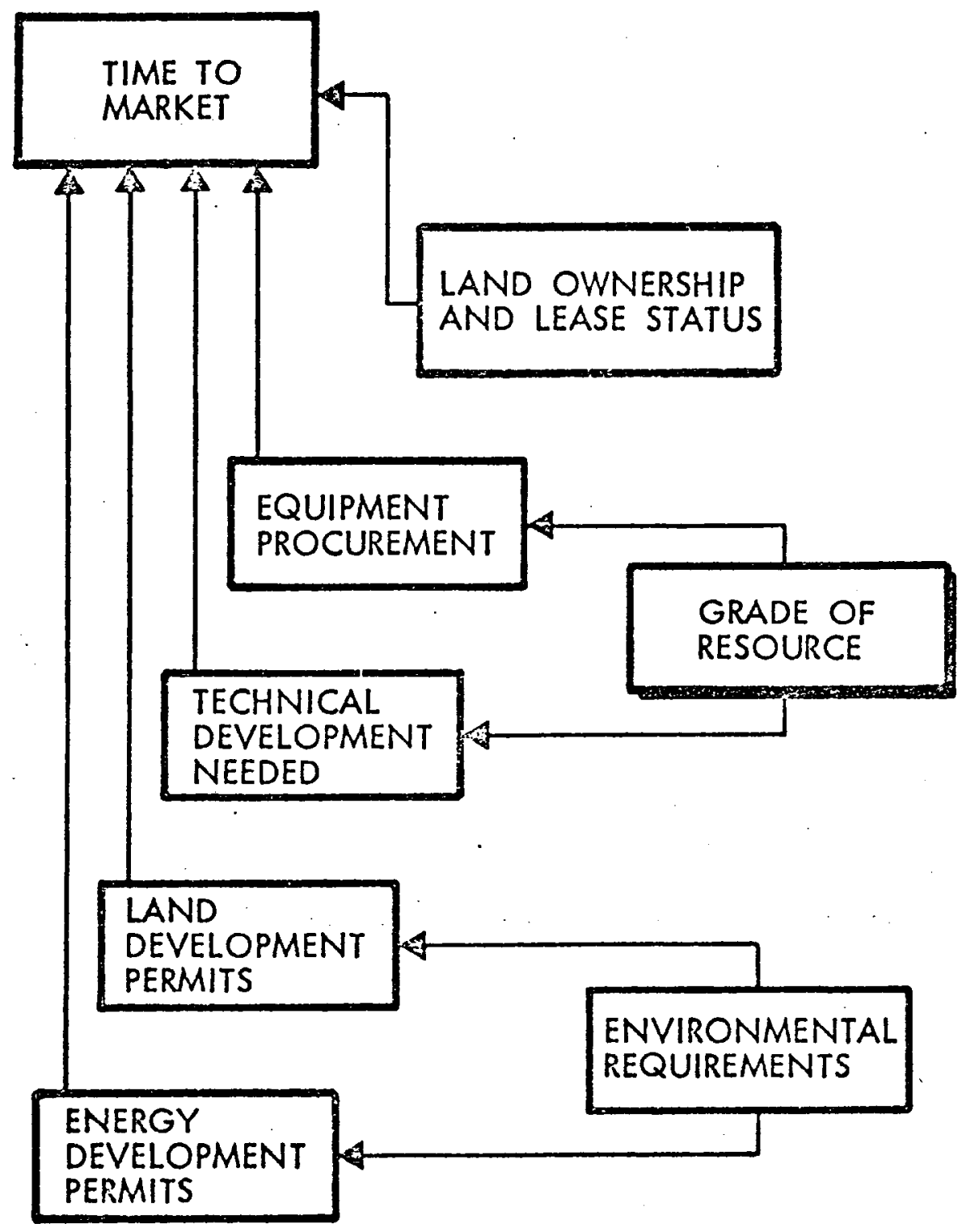

RANKING CRITERIA - TIME TO MARKET

Figure 4 


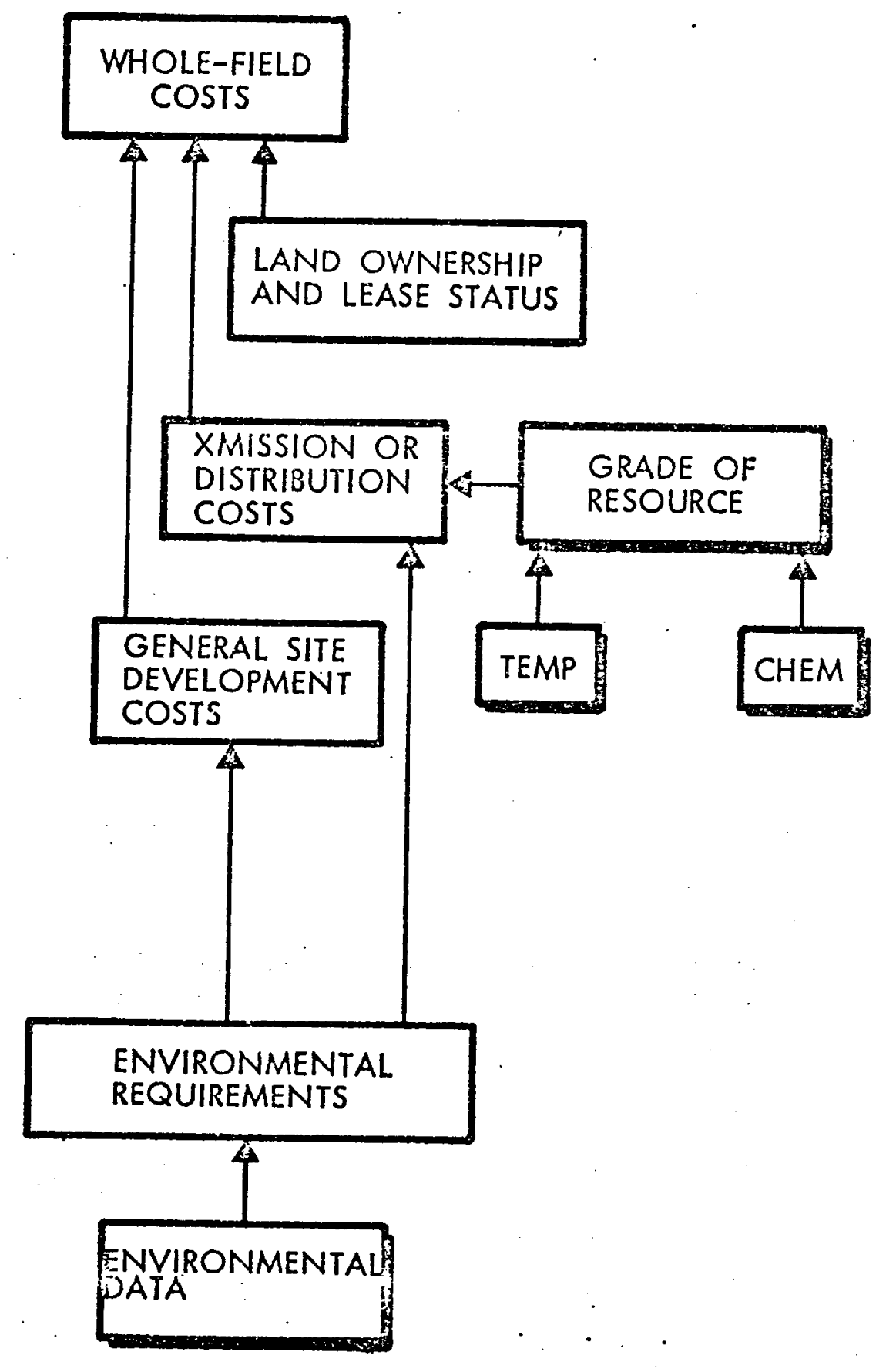

Figure 5

RANKING CRITERIA - WHOLE-FIELD COSTS 


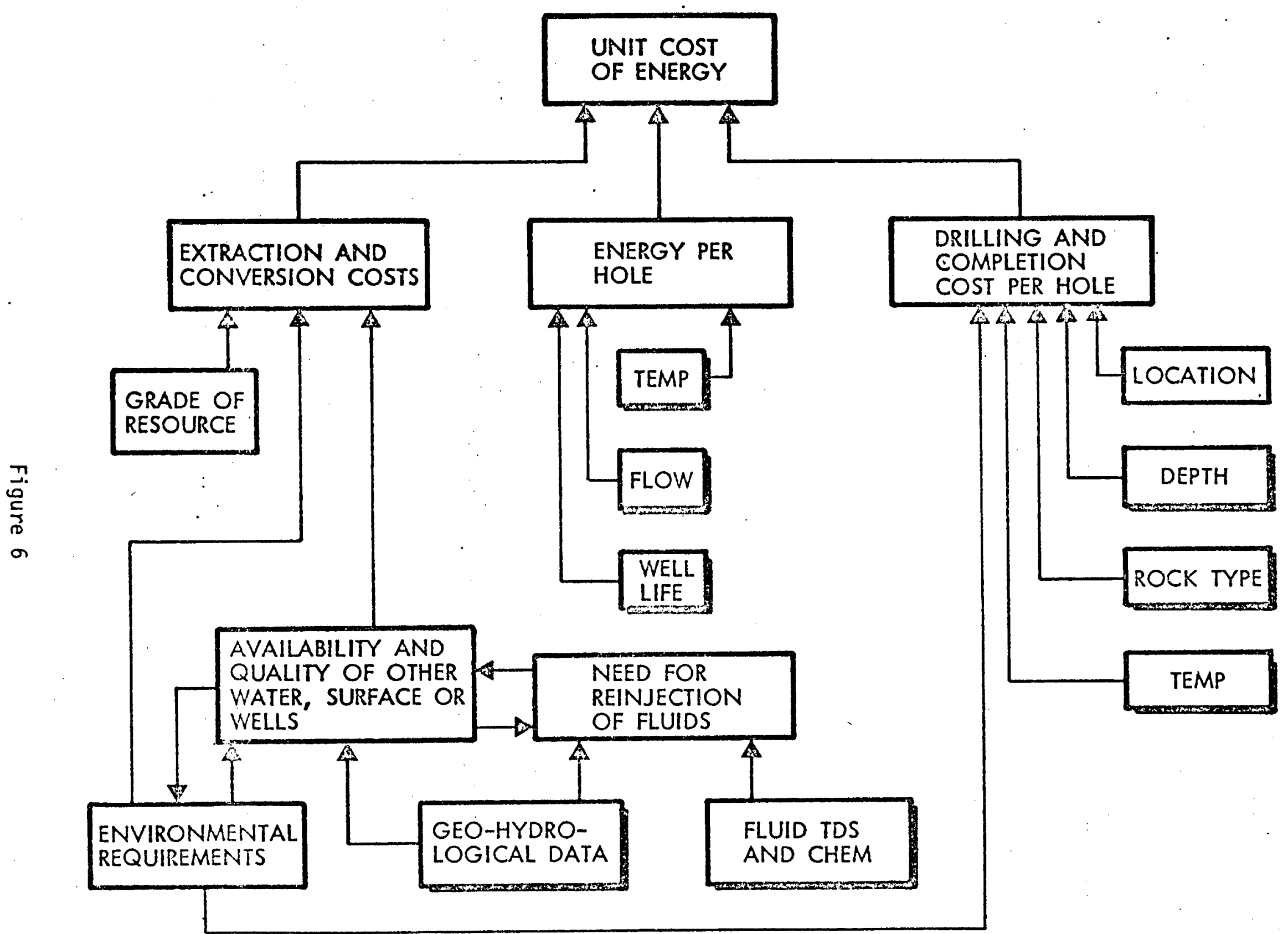




\section{GEOTECHNICAL EVALUATION}

A large percentage of the land area in the western United States offers the potential for geothermal resource discovery and exploitation. The geothermally-interesting area in the western states is depicted in Figure 7 along with the 13 prospects of interest here and the 66 known Geothermal Resource Areas (KGRA), that had been defined on April 30, 1975. KGRAs are areas designated by the Federal government as prospects that have commercial development potential or for which competitive interest in land leasing has been exhibited.

Appendix A contains a general discussion of the regional geology and geotechnical data.

\subsection{Geotechnical Data Types}

The geotechnical data used in comparing and ranking the specific prospects have been classified by type and summarized in matrix form. While the various data types are treated individually, it is important to recognize that a data assemblage may be more important than individual data types. Relatively weak data of several types that integrate into a single cohesive result may be more valuable than relatively strong but conflicting data of several types. The geotechnical data, summarized in Tables 2 and 3, is readily divided into several subclasses, i.e., surface data, geophysics, subsurface data, geochemistry, and reservoir characteristics.

\subsubsection{Surface Data}

Surface mapping of the geological units and tectonic features has been done in all instances by the U.S. Geological Survey and/or state geological surveys with a uniform, excellent quality. All of the prospects except chandler are marked by thermal springs. Table 2 indicates the temperature and chemical content of the thermal spring waters. 
R $0 \quad 75-27$
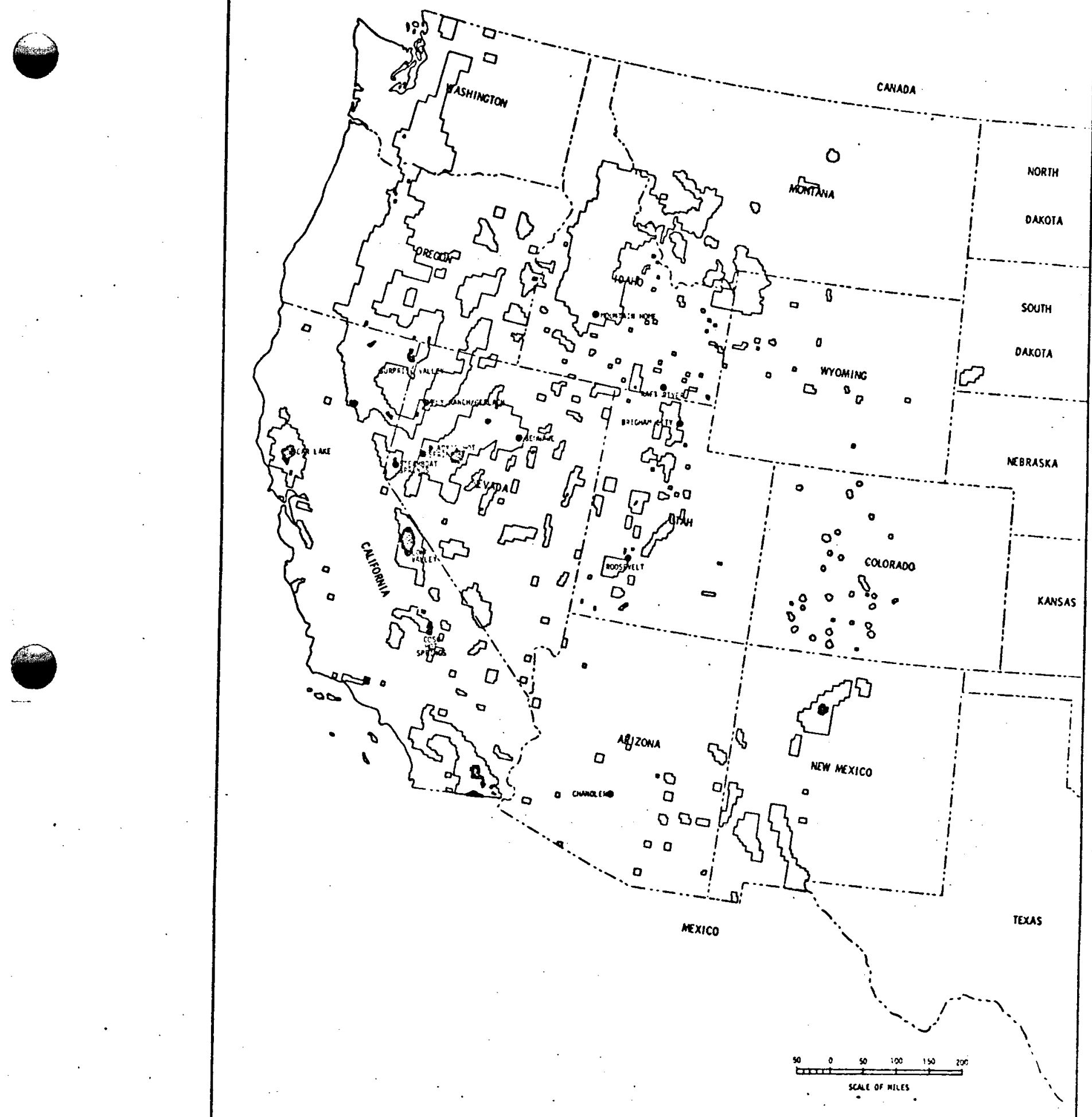

AREAS OF GEOTHERMAL INTEREST IN THE WESTERN UNITED STATES

FIGURE 7 


\begin{tabular}{|c|c|c|c|c|c|c|c|c|c|}
\hline \multirow{3}{*}{$\vdots$} & \multicolumn{2}{|c|}{ Thermal Springs } & \multicolumn{7}{|c|}{ Geophysics } \\
\hline & \multirow{2}{*}{$\begin{array}{l}\text { Observed } \\
\text { Temp. } \\
\left({ }^{\circ} \mathrm{F}\right)\end{array}$} & \multirow{2}{*}{$\begin{array}{l}\text { Chemical } \\
\text { Content } \\
\text { (TDS) }\end{array}$} & \multirow{2}{*}{$\begin{array}{l}\text { Heat } \\
\text { Flow }\end{array}$} & \multirow{2}{*}{$\begin{array}{c}\text { Electrical/ } \\
\text { Electromag- } \\
\text { netic }\end{array}$} & \multicolumn{3}{|c|}{ Seismic } & \multirow[b]{2}{*}{ Gravity } & \multirow[b]{2}{*}{ Magnetics } \\
\hline & & & & & $\begin{array}{l}\text { Micro- } \\
\text { quakes }\end{array}$ & Noise & Refraction & & \\
\hline Roosevelt, Utah & 185 & 7,040 & -- & A & -- & -- & -- & $E$ & $E$ \\
\hline Beowawe, Nevada & 205 & 1,200 & -- & -- & $E$ & $E$ & -- & $E$ & $E$ \\
\hline Coso Hot Springs, Calif. & 200 & 2,000 & A & $A$ & A & A & $E$ & $E$ & $E$ \\
\hline Long Valley, Calif. & 200 & 2,000 & $\mathbf{E}$ & A & $E$ & $E$ & $E$ & $A$ & -- \\
\hline Brady's Hot Springs, Nev. & 209 & 2,450 & -- & -- & -- & -- & - & $\varepsilon$ & $E$ \\
\hline Steamboat Springs, Nev. & 206 & 2,500 & $-\infty$ & -- & -- & -- & -- & -- & -- \\
\hline Clear Lake, Calif. & 180 & -- & -- & A & -- & -- & $E$ & $A$ & $E$ \\
\hline Surprise Valley, Calif. & 200 & 1,500 & -- & $A$ & $E$ & $E$ & -- & $E$ & $E$ \\
\hline Fly Ranch/Gerlach, Nev. & 220 & -- & -- & $E$ & $E$ & -- & -- & - & -- \\
\hline Mountain Home, Idaho & 150 & 300 & -- & -- & -- & -- & -- & $-\infty$ & $\ldots$ \\
\hline Raft River, Idaho & 212 & -- & $A$ & $A$ & -- & - & A & E & $E$ \\
\hline Brigham City, Utah & 125 & 40,000 & -- & A & -- & -- & -- & E & E \\
\hline Chandler, Arizona & --- & -- & -- & A & -- & -- & -- & $E$ & $E$ \\
\hline & & SURFACE & GEOTE & $\begin{array}{l}\text { HNICAL DATA } \\
\text { ble } 2 .\end{array}$ & SUMBIARY & $\begin{array}{l}E \\
A\end{array}$ & $\begin{array}{l}\text { Data unav } \\
\text { Data avai } \\
\text { Data avai }\end{array}$ & $\begin{array}{l}\text { ailajle } \\
\text { lable } \\
\text { lable \& s }\end{array}$ & ignificant \\
\hline
\end{tabular}




\begin{tabular}{|c|c|c|c|c|c|c|c|c|}
\hline & \multicolumn{3}{|c|}{ Subsurface Data } & \multicolumn{2}{|c|}{ Geochemistry } & \multirow{2}{*}{\multicolumn{2}{|c|}{$\begin{array}{c}\text { Reservoir } \\
\text { Characteristics }\end{array}$}} & \\
\hline & \multicolumn{3}{|c|}{ Wells } & \multicolumn{2}{|c|}{ Well Fluids } & & & \\
\hline. & $\begin{array}{l}\text { Depth } \\
\text { (ft.) }\end{array}$ & $\begin{array}{c}\text { Geophysical } \\
\text { Logs }\end{array}$ & $\begin{array}{l}\text { Core/Sample } \\
\text { Descriptions }\end{array}$ & $\begin{array}{l}\text { Chemical } \\
\text { Content } \\
\text { (TDS) }\end{array}$ & $\begin{array}{c}\text { Chemical } \\
\text { Temperature } \\
\left({ }^{\circ} \mathrm{F}\right)\end{array}$ & $\begin{array}{l}\text { Observed } \\
\text { Temperature } \\
\left({ }^{\circ} \mathrm{F}\right)\end{array}$ & $\begin{array}{l}\text { Flow } \\
\text { (GPM) }\end{array}$ & \\
\hline Roosevelt, Utah & 2,800 & -- & -- & -- & 540 & $>420$ & 400 & \\
\hline Beowawe, Nevada & 9,563 & -- & -- & 1,200 & 470 & 414 & -- & \\
\hline Coso Hot Springs, Calif. & 375 & $\therefore$ & $E$ & 5,750 & 440 & 287 & 40 & \\
\hline Long Valley, California & 1,060 & -- & -- & 1,500 & 440 & 352 & 1000 & \\
\hline Brady's Hot Springs, Nevada & 5,100 & -- & -- & 2,500 & 380 & 418 & 120 & \\
\hline Steamboat Springs, Nevada & 1,830 & - & -- & low & 380 & 369 & -- & \\
\hline Clear Lake, California & 8,566 & $\cdot-$ & -- & low & -- & 367 & -- & \\
\hline Surprise Valley, Calif. & 4,500 & -- & -- & low & 340 & 320 & - & \\
\hline Fly Ranch/Gerlach, ivevada & 1,000 & -- & -- & low & 340 & 220 & -- & $\approx$ \\
\hline Mountain Home, Idaho & 9,700 & -- & - & 800 & -- & 382 & $1000 / 0$ & 0 \\
\hline Raft River, Idaho & 6,000 & E & -- & $<2,000$ & 300 & 297 & 1000 & Gr \\
\hline Brigham City, Utah & 11,000 & -- & -- & 54,000 & 400 & 284 & 0 & 1 \\
\hline Chandler, Arizona & 10,000 & - & -- & 60,000 & -- & 352 & $3000 / 0$ & $\sim$ \\
\hline & & FACE GEOTE & $\begin{array}{l}\text { HNICAL DA } \\
\text { le } 3 .\end{array}$ & UMMIARY & $\begin{array}{r}\text {-- Data } \\
\text { E Data } \\
\text { A Data }\end{array}$ & $\begin{array}{l}\text { ravailable } \\
\text { vailable } \\
\text { vailable \& si }\end{array}$ & nificant & \\
\hline
\end{tabular}




\subsubsection{Geophysics}

Table 2 also summarizes geophysical data in the prospect areas in terms of being unavailable, available and available with significant results. Significant results are defined as those that provide direct evidence (recognizing the interpretational nature of geophysical data) of the presence or non-presence of a geothermal resource.

\subsubsection{Subsurface Data}

Well depths, indicated in Table 3, vary from shallow to deep. Historically, shallow (less than 2000 feet) wells have not been successful, although adequate temperatures and flows have been initially encountered. The principal reasons appear to be that the flow from shallow wells may interact with near-surface groundwater in the immediate vicinity with a consequent cooling and precipitation of minerals, and that a relatively unconsolidated and unstable shallow reservoir may collapse and clog as fluid is removed. Deep wells, of course, are more expensive. In general; the range of reservoir depths that allows reliable production at a reasonable cost appears to be from 2000 to 6000 feet. All the wells listed here, except those at Coso and Raft River, have been drilled by private concerns, whose usual practice is to hold data such as geophysical well logs and core descriptions proprietary for as long as state regulations permit, or until the prospect is fully developed or abandoned.

\subsubsection{Geochemistry}

In general, as listed in Table 3, the geothermal waters contained in these prospects are of low salinity, with a few thousand parts per million (ppm) of total dissolved solids (TDS). (For comparison, sea water salinity is a nominal 35,000 ppm.) Exceptions are at Brigham City and Chandler, where the fluids contain higher salt percentages than the sea. Even the low salinity fluids, though, will not usually be allowed to mingle with fresh surface or shallow aquifer water. An exception is Mountain Home, where the water is potable when cold, and would be permitted to flow into surface waters. The geothermal water is generally of sufficient 
quality to be used for evaporative cooling, surface subsidence considerations permitting. Accordingly, developments at most prospects can probably supply cooling water internally without drawing on other surface or subsurface sources and without excessive scaling and corrosion in condensers and heat exchangers.

The chemical estimates of reservoir temperature listed in Table 3 are general averages, subjectively weighted, from various chemical analys is of hot springs and well fluids obtained at the prospect sites. This includes both $\mathrm{SiO}_{2}$ and $\mathrm{Na}-\mathrm{K}-\mathrm{Ca}$ estimates. The range of temperatures obtained from different geochemical determinations at any one site can easily be as large as $60^{\circ} \mathrm{F}$ or more. The weighting, based on geochemistry, has generally favored the higher more reliable values since the principal use of chemical estimates is as an indicator of maximum potential.

\subsubsection{Reservoir Characteristics}

The maximum observed temperatures, in the tabulated wells, have mostly been measured under conditions of little or no flow and not necessarily from the bottom of the deepest well on the site. Fluid temperatures at the wellheads of flowing wells may be considerably lower than down-hole reservoir temperature, particularly where the fluid is lifted by flashing in the well.

Data on individual well flow rates are sparse, and should not be assumed as representative of flow rates to be expected from production wells, whose depth, completion technique, and local situation may be very different from those of the exploration wells.

\subsection{Cost Data}

Figure 8 shows geothermal well costs as a function of depth. These data were assembled from a variety of estimates of well costs from various years between 1971 and 1974, all escalated to 1975 dollars at the high but realistic rate of $20 \%$ per year. The wide range upward from average $0 i 1$ and gas well costs reflects the problems of drilling in volcanic 


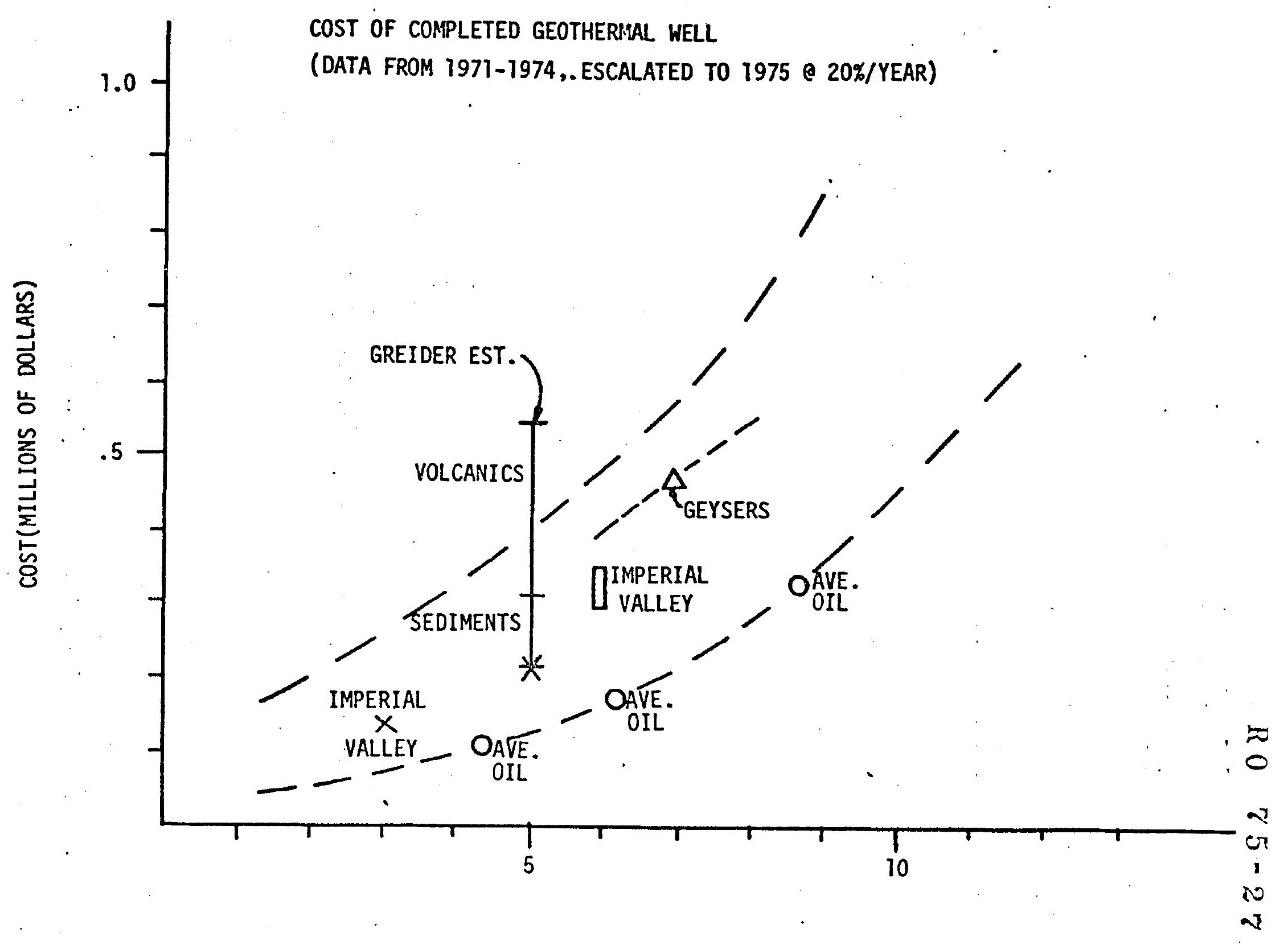


and metamorphic rock types not associated with oil drilling and the problems of drilling and completing hot wells. Figure 9 shows the gross electric power that can be drawn from a flow of 1000 GPM of geothermal fluid, as a function of fluid temperature, using optimum conversion technology. Note that binary conversion is optimum to approximately $420^{\circ} \mathrm{F}$ and flash conversion is optimum at higher temperatures. Note further that the energy versus temperature slope is steeper for flash than binary. The data'from these two figures can be combined to derive nominal well cost per KWe capacity installed, as functions of temperature and depth. This will be used in Section 7 below in determining the prospect ranking.

For fluids of similar chemical content, the cost of energy conversion depends primarily on fluid temperature. Binary conversion plant costs, without wells and collection system, decrease almost linearly from $\$ 450 /$ KWe at $300^{\circ} \mathrm{F}$ to $\$ 330 / \mathrm{KWe}$ at $420^{\circ} \mathrm{F}$ (Ref. 1 ). The costs of flash conversion plants are markedly less. The data important to this analysis is the cost slope of minus $\$ 1 / \mathrm{KWe}$ per ${ }^{\circ} \mathrm{F}$ for geothermal fluids ranging in temperature from $300^{\circ} \mathrm{F}$ to $420^{\circ} \mathrm{F}$. These costs will also be used in Section 7 in prospect ranking. 
(6)

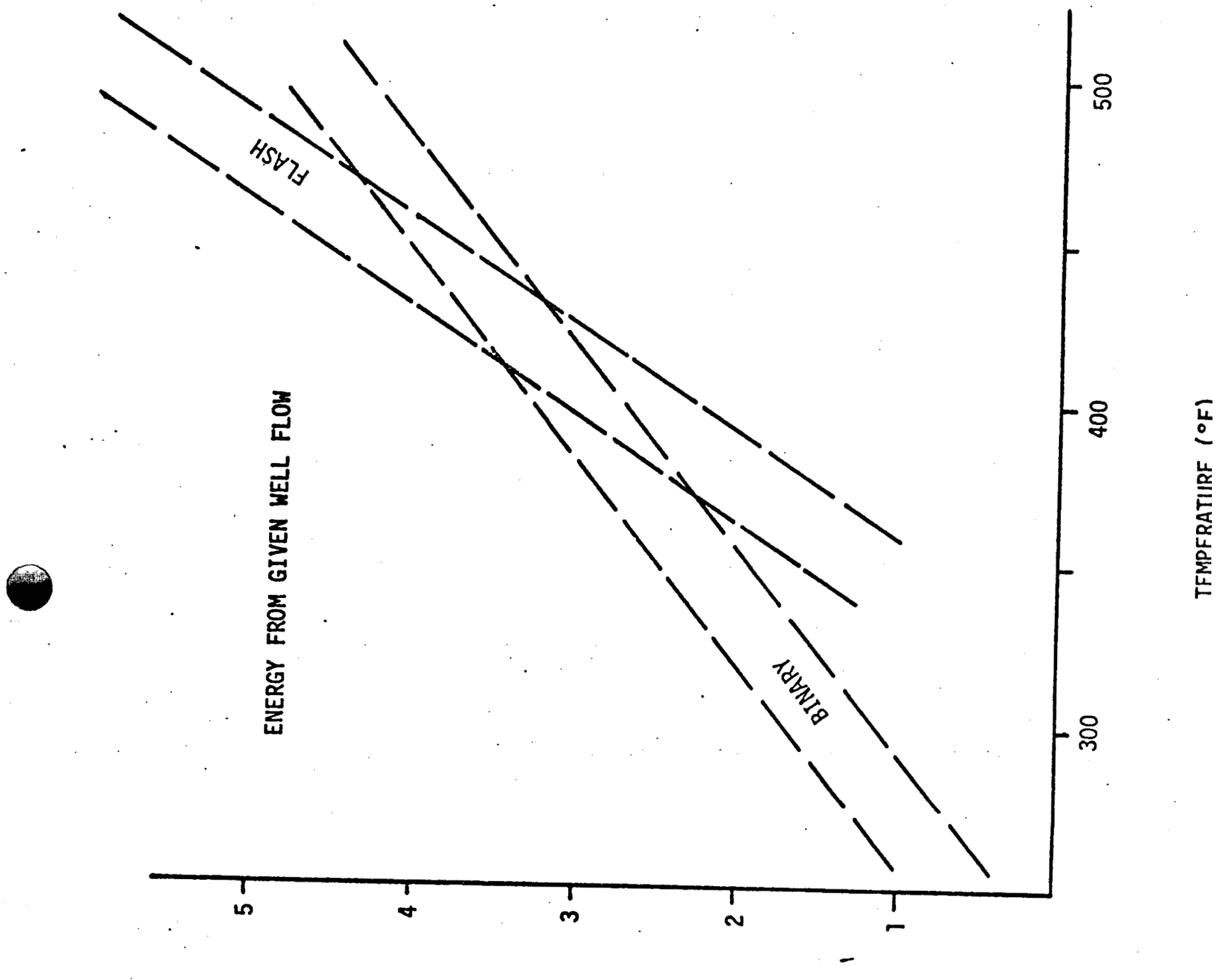

- M07J. Wd9000L/OMW

Figure 9 


\section{LOAD CENTER EVALUATION}

The economic worth of a geothermal resource is in part a function of the investiment that must be made in an energy distribution system and this is a function of the proximity of the user (the load center) to the resource. Two uses of geothermal energy are considered, electrical power generation and direct use of fluids for space/process heating.

\subsection{Electric Power Generation}

Several Southern California utility companies (Southern California Edison, San Diego Gas and Electric, and the municipal utilities of the cities of Burbank and Riverside have stated the following general requirements as necessary for justifying an electrical generating plant at any specific geothermal site: (Ref. I)

- If the site is intended to serve a sniall isolated load center (Long Valley near Mammoth, California for example) proven reserves of 10-15 MWe, expected to last for 30 years, are required.

- If the site is near a large load center (Imperial Valley fields near Los Angeles and San Diego, for example), proven reserves of 50 Mlle for 30 years, and potential reserves of 200-400 Mlle, are required.

- If the site is remote from a large load center (Central Nevada fields for example), potential reserves of 1000 to 2000 MHe are required. However, representatives of the Electrical Power Research Institute (EPRI) have suggested that proven reserves of 200 Mwe anywhere will be a commercial resource.

An important factor in the economic viability of a geothermal prospect is thus the distance to the nearest electrical transmission network capable of carrying the load. Figure 10 shows the existing network (solid lines) and planned additions through 1984 (dashed lines). This network is compiled from data supplied by the major western utilities and represents approximately 95 percent of the total network (Ref. 2). Transmission lines operated by small, local utilities are not displayed.

Table 4 summarizes the proximity of the thirteen prospects to the network of Figure 10. With one exception (Fly Ranch/Gerlach), all prospects 

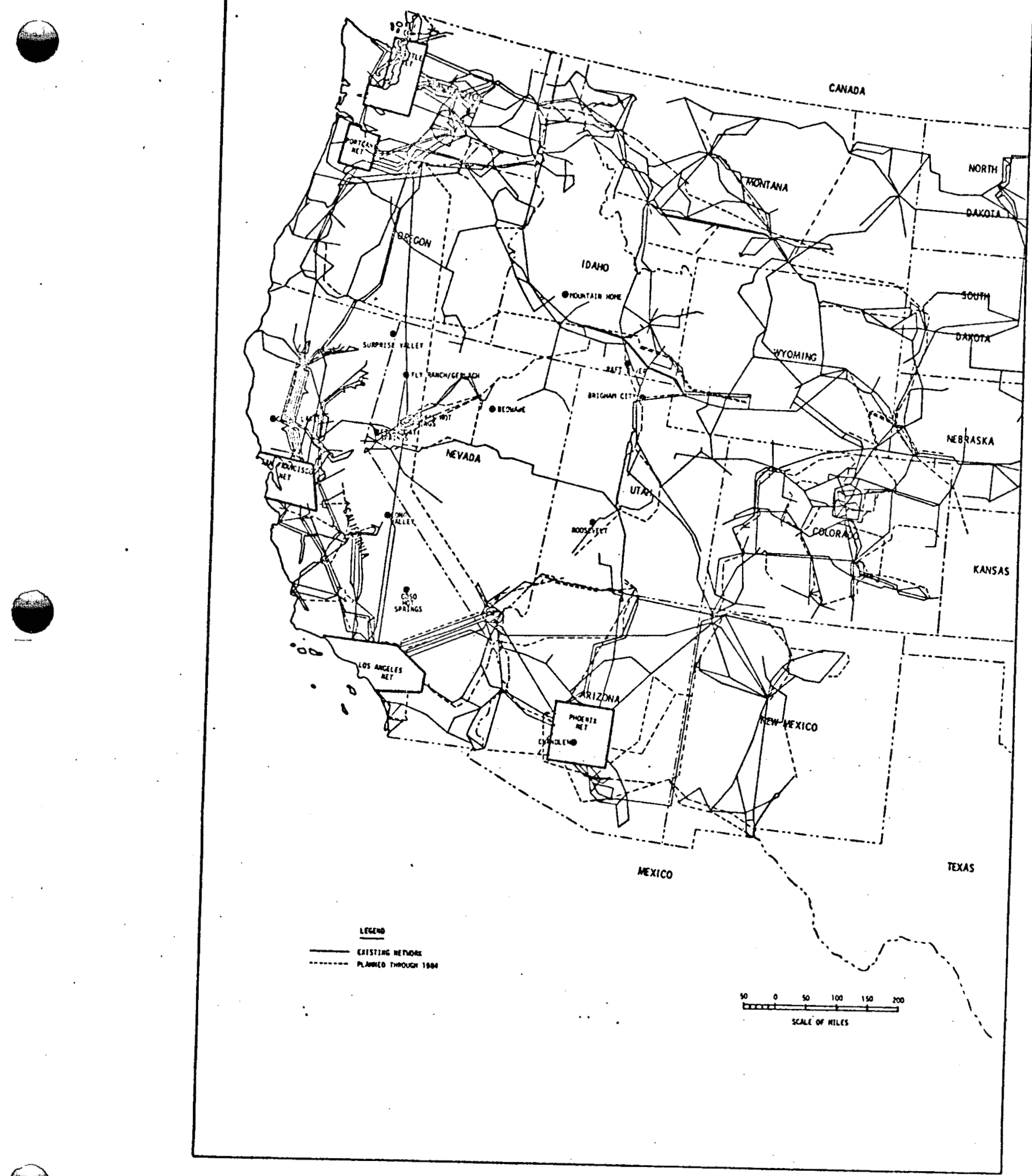

ELECTRICAL POWER DISTRIBUTION NETWORK

FIGURE 10 
TABLE 4 - USER PROXIMITY DATA SUMMARY

\begin{tabular}{|c|c|c|c|}
\hline \multirow[b]{2}{*}{ - } & \multirow{2}{*}{$\begin{array}{c}\text { Approximate } \\
\text { Distance To } \\
\text { Electrical } \\
\text { Transmission } \\
\text { Line } \\
\text { (Miles) }\end{array}$} & \multicolumn{2}{|c|}{ Space/Process Heating } \\
\hline & & $\begin{array}{c}\text { Radius of* } \\
\text { Population, } \\
10,000 \\
\text { (Miles) }\end{array}$ & $\begin{array}{l}\text { Radius of * } \\
\text { Population, } \\
100,000 \\
\text { (Miles) }\end{array}$ \\
\hline Roosevelt, Utah & 20 & 35 & 130 \\
\hline Beowawe, Nevada & 25 & 80 & 200 \\
\hline Coso Hot Springs, California & 20 & 40 & 100 \\
\hline Long Valley, California & 20 & 35 & 150 \\
\hline Brady's Hot Springs, Nevada & $<10$. & 40 & 100 \\
\hline Steamboat Springs, Nevada & $<10$ & $<10$ & 20 \\
\hline Clear Lake, California & 10 & 30 & 50 \\
\hline Surprise Valley, California. & 30 & 40 & 150 \\
\hline Fly Ranch/Gerlach, Nevada & 30 & 70 & 100 \\
\hline Mountain Home, Idaho & 10 & 10 & 50 \\
\hline Raft River, Idaho & 30 & 25 & 120 \\
\hline Brigham City, Utah & $<10$ & $<10$ & 30 \\
\hline Chandler, Arizona & $<10$ & $<10$ & 25 \\
\hline
\end{tabular}


lie within 50 miles of an existing transmission line. Accordingly, transmission line proximity does not appear to be a major consideration in the development potential of the selected prospects.

\subsection{Space/Process Heating}

Geothermal waters are now used for residential heating and greenhouse warming at Surprise Valley, Steamboat Springs, and Raft River, and several other areas not included in the present prospect list. This usage is unorganized and very individualistic.

A basic problem with hot water and/or steam is that it does not transport well. Hot water is transported by pipeline over 12 miles in Iceland for space heating purposes and steam is transported up to 45 miles in Italy (Reference 3). It appears that transporting water for 50 miles is reasonable and prospects have been evaluated on that basis.

As indicated in Table 4, three prospects (Chandler, Brigham City and Steamboat Springs) are close enough to population centers to present opportunities for space heating development. Steamboat Springs is of particular interest. Representatives of the State of Nevada have stated that space heating using Steamboat Springs geothermal waters may be the next major geothermal development in the state, preceding electric power development. These officials described housing developments in the Steamboat Springs area being arranged so that four homes would mutually share one geothermal well. The idea is in the conceptual stage and such factors as reinjection have not been considered.

Considering a population of several hundred thousand within distribution range, however, the demand for thermal energy in residential and commercial space heating is equivalent to no more than some thousands of barrels of oil per day. Further, the demands of special industries that could be attracted to a new site by inexpensive process heat or hot water would probably not be large. By contrast, the demand of the same population for electric power would be some hundreds of MWe equivalent to several tens of thousands of barrels of oil per day. For example, direct use of heat from a major geothermal development at Steamboat Springs would only 
use a small fraction of the available power.

All of these geothermal prospects are directed at the same electric power market in the western states. These states are connected by an intertie system that can distribute power from any source to any load center over its entire area. The market is much larger than the combined potential of all the selected prospects; therefore, development of the geothermal resource would aid in supplying the market, but would not affect its structure. While individual utility companies tend to formulate plans based on projected power demands in their own areas, they are also accustomed to entering into long-and/or short-term agreements to assure power supply to the total market area. 


\section{EVALUATION OF ADMINISTRATIVE REGULATIONS AND CONSTRAINTS}

A substantial portion of the development time-to-market for a geothermal resource is the time required to obtain approvals from government agencies. Approval delays have a direct bearing on the economics of development and thus directly affects the potential of geothermal prospects.

The most significant differences in administrative requirements for joethermal development are exhibited state by state, rather than prospect by prospect. The procedure and regulations adopted by local county governments are generally similar within any state. Most counties assume a minor role in the regulation of geothermal activity and the state assumes the major responsibility except in California where local government exercises significant control. Additional details are contained in Appendix B.

Table 5 provides a summary of the county level administrative constraints imposed on geothermal developers and summarizes the status of land at the prospects in California. Local agencies in California have the most stringent and time-consuming administrative requirements, but for the prospects included in this study, the requirements are similar. Nevada county constraints on geothermal activities are very limited; those that are imposed are implemented with a positive attitude toward development. The county governments of Utah, Idaho, and Arizona have not yet enacted control regulations and administrative constraints at the county level are practically non-existent.

Geothermal development regulations and procedures also depend substantially on ownership of the land (F́ederal, state, or private). While most of the prospect areas contain both Federal and private lands, most exploration has been done on private land. This is directly attributable to the difficulties of acquiring Federal leases; a geothermal developer faces the greatest procedural and regulatory difficulties when proposing to explore or develop Federal land. Difficulties are multiplied in states with stringent requirements; on the other hand, a developer may face only 
TABLE 5 COUNTY ADMINISTRATIVE REQUIREMENTS FOR GEOTHERMAL DEVELOPMENT AND' STATUS OF LAND IN CALIFORNIA PROSPECTS

Clear Lake

Definitive control procedures have been enacted.

- EAR for exploration Tand use permit (possible EIS if required)

- EIS required for de-

\begin{tabular}{|c|c|c|}
\hline $\begin{array}{l}\text { Characterization } \\
\text { of constraints }\end{array}$ & $\begin{array}{l}\text { Disposition of } \\
\text { county } \\
\text { administration }\end{array}$ & Land status \\
\hline $\begin{array}{l}\text { Stringent. } \\
\text { Administrative } \\
\text { requirements pose signi- } \\
\text { ficant constraints and } \\
\text { long delays }\end{array}$ & Very cautious. & $\begin{array}{l}\text { Principal site } \\
\text { is on Federal } \\
\text { land, U.S. } \\
\text { military } \\
\text { reservation. }\end{array}$ \\
\hline $\begin{array}{l}\text { Stringent. } \\
\text { Administrative require- } \\
\text { ments pose significant } \\
\text { constraints and long } \\
\text { delays. }\end{array}$ & $\begin{array}{l}\text { Positive: Local } \\
\text { private interest groups } \\
\text { and Sierra Club pose } \\
\text { difficulties. }\end{array}$ & $\begin{array}{l}\text { Private and } \\
\text { Federal }\end{array}$ \\
\hline $\begin{array}{l}\text { Stringent. } \\
\text { Administrative require- } \\
\text { ments pose significant } \\
\text { constraints and long } \\
\text { delays. }\end{array}$ & $\begin{array}{l}\text { Cautious. Air pollu- } \\
\text { tion control district } \\
\text { is advisiing studies be } \\
\text { conducted to determine } \\
\text { probable air quality im- } \\
\text { pacts. Sierra club and } \\
\text { private interest groups } \\
\text { pose difficulties. }\end{array}$ & $\begin{array}{l}\text { Federal. Mineral } \\
\text { rights to all pri- } \\
\text { vate lands within } \\
\text { KGRA are retained } \\
\text { by Federal govt. }\end{array}$ \\
\hline $\begin{array}{l}\text { Stringent. } \\
\text { Administrative require- } \\
\text { ments pose significant } \\
\text { constraints and long } \\
\text { delays. }\end{array}$ & $\begin{array}{l}\text { Cautious. County is } \\
\text { anticipating potential } \\
\text { conflict with BLM for } \\
\text { control of Federal } \\
\text { lands. }\end{array}$ & $\begin{array}{l}\text { Private and } \\
\text { Federal. All } \\
\text { exploration has } \\
\text { been on private } \\
\text { land. }\end{array}$ \\
\hline
\end{tabular}


mild constraints and brief delays when operating on private land in states with more lenient regulations.

The severity of constraints generated by regulations and policies depends on five factors:

- The number of reviewing agencies in the approval processes, i.e., in California, as many as 40 , in Arizona, one..

- The delays associated with the approval processes. Many procedures do not stipulate a time target.

- The nature and disposition of the reviewing agencies.

- The disposition of private-interest groups such as the sierra Club.

- The complexity and the technical consequences of requirements to be implemented.

Table 6 is an assessment of each prospect considering the above factors. Available information has been combined into a three-tier scale for each factor, which has been used to rate the regulatory severity associated with exploring and developing each prospect. For prospects which might be developed on lands other than Federal, Table 6 provides alternate severity ratings as explained in the footnotes.

Federal constraints and delays are in addition to and not instead of constraints that can be imposed by state and local authorities. The administrative delays which are added will depend in large part on if an Environmental Assessment Report (EAR) or Environmental Impact Statement (EIS) has been prepared and the degree of coordination required between state, local, and Federal agencies to resolve separate interests and requirements of each. Since the second factor depends upon the first, the greatest coordination problems occur during preparation of the EAR or EIS. Significant delays are probable for prospects on Federal'lands where EAR's have not yet been prepared. This problem will be compounded in states where numerous agencies must coordinate with Federal authorities for preparation of an EAR. Table 7 summarizes the effects of Federal requirements for geothermal resource development. This information is incorporated into the overall assessment of Table 6. 
TABLE 6 ASSESSMENT OF PROSPECTS BY ADMINISTRATIVE REQUIREMENTS

\begin{tabular}{|c|c|c|c|c|c|c|c|c|c|c|}
\hline \multirow{3}{*}{ PROSPECT } & \multirow{3}{*}{$\begin{array}{l}\text { STATUS OF } \\
\text { PROBABLE } \\
\text { DEVELOPMENT } \\
\text { LAND }\end{array}$} & \multicolumn{6}{|c|}{ SEVERITY IMDEX } & \multicolumn{3}{|c|}{ SUMMARY } \\
\hline & & $\begin{array}{l}\text { NUMBER } \\
\text { OF } \\
\text { AGENCIES }\end{array}$ & DELAYS & $\begin{array}{c}\text { DISPOSITION } \\
\text { GOVERNMENT } \\
\text { AGENCIES }\end{array}$ & $\begin{array}{l}\text { OF } \\
\text { PRIVATE } \\
\text { INTERESTS } \\
\end{array}$ & $\begin{array}{l}\text { TYPE OF } \\
\text { AGENCIES }\end{array}$ & $\begin{array}{l}\text { CONSTRAIN- } \\
\text { ING CHAR- } \\
\text { ACTER OF } \\
\text { REGULATIONS }\end{array}$ & \multirow[t]{2}{*}{$\begin{array}{l}\text { HIGHEST } \\
\text { SEVERITY } \\
\text { INDEX } \\
\text { VALUE }\end{array}$} & \multirow[t]{2}{*}{$\begin{array}{l}\text { TOTAL } \\
\text { VALUE }\end{array}$} & \multirow[t]{2}{*}{$\begin{array}{l}\text { TOTAL OVERALL } \\
\text { VALUE WHEN } \\
\text { FEDERAL LAND IS } \\
\text { DEVELLOPED }\end{array}$} \\
\hline & & \multicolumn{6}{|c|}{ (Value of Severity Factor on a Scale of 3 ) } & & & \\
\hline \multicolumn{11}{|l|}{ CALIFORNIA } \\
\hline Coso Hot Springs & Federal & 3 & 3 & 1 & 2 & 2 & 2 & 3 & 13 & Not Applicable \\
\hline Long Valley & Private $^{\mathbf{a}}$ & $3(3+)$ & $2(3)$ & 1 & 3 & 1 & 2 & 3 & 12 & $13+$ \\
\hline Clear Lake & Federal & 3 & 2 & 2 & 3 & 2 & 2 & 3 & 14 & Not Applicable \\
\hline Surprise Valley & Private & $3(3+)$ & $3(3+)$ & 1 & 3 & 1 & 2 & 3 & 13 & $13+$ \\
\hline \multicolumn{11}{|l|}{ NEVADA } \\
\hline Beowawe & Private/Federal ${ }^{b}$ & 1 & 1 & 1 & 1 & 1 & $?$ & 1 & 6 & No Change \\
\hline Brady's Hot Springs & Private/Federal ${ }^{\mathrm{b}}$ & 1 & 1 & 1. & 1 & 1 & 1 & 1 & 6 & No Change \\
\hline Fly Ranch & Private/Federal ${ }^{\mathbf{b}}$ & 1 & 1 & 1 & 1 & 1 & 1 & 1 & 6 & No Change \\
\hline Steamboat Springs & Private/Federal ${ }^{b}$ & 1 & 1 & 1 & 1 & 1 & 1 & 1 & 6 & No Change \\
\hline \multicolumn{11}{|l|}{ UTAH. } \\
\hline Roosevelt & Federal & 1 & 1 & 1 & 1 & 1 & 1 & 1 & 6 & Not Applicable \\
\hline Brigham City & Private & $1(2)$ & $1(2)$ & 1 & 1 & 1 & 1 & 1 & 6 & 8 \\
\hline \multicolumn{11}{|l|}{ IDAHO } \\
\hline Mounta in Home & Federal & 1 & 1 & 1 & 1 & 1 & 1 & 1 & 6 & Not Applicable \\
\hline Raft River & Federal/Private & 1 & 1 & 1 & 1 & 1 & 1 & 1 & 6 & No Change \\
\hline \multicolumn{11}{|l|}{ ARIZONA } \\
\hline Chandler & Private & $1(2)$ & (2) & 1 & 1 & 1 & 1 & 1 & 6 & 8 \\
\hline
\end{tabular}

a Although both Federal and private lands exist at the site, geothe mal d veloo er . ss assumed to be nost probable on private lands owing to: (1) previous drilling history on private lands oniy, and $(z)$ the peth of lest os stace rori the standpuint of administrative constraints.

b Development on either private or Federal land was estimated equally probsole, al a'd sccur with no significant difference in regulatory requirements.

Notes:

1. Figures in parenthesis indicate value of obstacle factors when develorment c.u r. rod.ral lands. 29 
TABLE 7 - CONTRIBUTION OF FEDERAL REQUIREMENTS TO SEVERITY INDICES

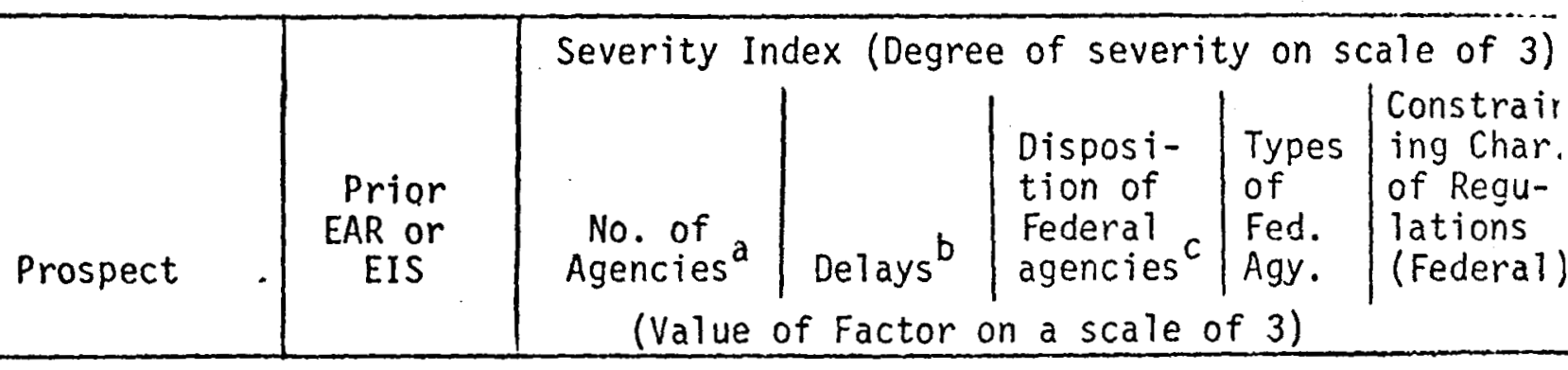

California

$\begin{array}{lllllll}\text { Coso Hot Springs } & \text { None } & 3 & 3 & 1 & 1 & 1 \\ \text { Long Valley } & \text { EIS } & 1 & 1 & 1 & 1 & 1 \\ \text { Clear Lake } & \text { EIS } & 1 & 1 & 1 & 1 & 1 \\ \text { Surprise Valley } & \text { EAR } & 1 & 1 & 1 & 1 & 1\end{array}$

Nevada

$\begin{array}{ll}\text { Beowawe } & \text { EAR } \\ \text { Brady's Hot Spgs } & \text { EAR } \\ \text { Fly Ranch } & \text { EAR } \\ \text { Steamboat Spgs } & \text { EAR }\end{array}$

Utah

Roosevelt EAR

Brigham City None

Idaho

Mountain Home

Raft River

Arizona

Chandler

\section{EAR \\ EAR}

None

1

1
1
1

1

$\begin{array}{ll}1 & 1 \\ 1 & 1 \\ 1 & 1 \\ 1 & 1\end{array}$

1

2

?

$\begin{array}{ll}1 & 1 \\ 1 & 1\end{array}$

$\begin{array}{ll}1 & 1\end{array}$

1

$\begin{array}{ll}1 & 1\end{array}$

1

2

1

1

a. The number of agencies involved in Federal land use depends on whether an EAR or EIS has been prepared. If neither, several staté and local authorities will be involved.

b In estimating delays, an EAR is assumed to suffice for approval of proposed activities; an EIS will not be required. Further, the delay associated with preparation of an EAR is assumed to be greater for California than for those states exercising limited authority.

c The disposition of the agencies involved in approval of Federal land uses is presumed to be progeothermal, stemming from the commitment of the Federal government to develop domestic energy resources. 
Table 6 shows that development of California prospects will encounter the most severe administrative hurdles. First, there are numerous agencies (local and state) which become involved in the reporting, review, and approval required by the California Environmental Quality Act. The greater the number of reviewers, the higher the probability of dissent and conflict. Second, the delays associated with the approval process are appreciable. Third, the recreational and scenic factors associated with California prospects suggest that dissent from private groups is probable. In addition, rederal land will or may be involved in all California development, compounding these problems. 


\section{ENVIRONMENTAL AND SOCIO-ECONOMIC SETTINGS AND EFFECTS}

At any prospect, part of the costs and delays associated with meeting requirements will depend on the environmental and socio-economic characteristics of the prospect as well as the administrative structure. Below is a discussion of those characteristics that may be a factor in development of the prospects and which may be sufficiently important to affect the relative development potential. Additional details are contained in Appendix C.

To evaluate these characteristics and to determine the differences between prospects, the baseline environment and economic base of each prospect and the surrounding area has been determined. The probable effects of each phase of development on the baseline have been evaluated. The sources of information for this are:

- Environmental Impact Statements or Environmental Assessment Reports filed for specific prospects or nearby areas

- General county plans applying to prospects

- Communications with county, state, and federal officials

- Prospect visits

Baseline conditions have been categorized under broad headings as follows:

- Physical environment comprising air quality, water supply, water quality, noise, topography, and aesthetics

- Biological environment comprising plant life, wildlife, aquatic life, and rare/endangered species

- Land use comprising land ownership, zoning, and current land use

- Socio-economics comprising culture, employment, population, public opinion, and future plans, along with historic and archeological sites

In summary, most of the prospects are in sparsely inhabited and arid or semi-arid areas. Exceptions are: 
- Clear Lake and Long Valley in wooded mountain areas with lakes and streams, that are used by urban dwellers for recreation

- Chandler, Brigham City, and Steamboat Springs on the outskirts of urban areas, within range of future expansion.

Development of prospects will no doubt be done in careful compliance with applicable environmental standards and regulations, particularly those concerned with water supply and quality, land subsidence, and air quality. This may involve significant costs for water reinjection, plant cooling, and gaseous effluent control. Geothermal development effects will be as follows:

- Environmental effects of drilling and construction, including removal of vegetation, reduction of wildlife habitats, erosion, dust, noise, and loss of aesthetic values. Regulation and care will generally localize and minimize these. Possible irreversible effects such as the destruction of rare and irreplaceable archaeological sites or habitats of endangered species, need careful consideration both in development and in long-term plant operations.

- Environmental effects of continuous production. Consideration must be given to such factors as consumptive use of water, subsidence risks, accidental air and water pollution, and permanent loss of aesthetic or historic values.

- Socio-economic effects, resulting from added work force in the area, during both construction and operational phases. The added population, including transient workers, permanent workers with families, and supportive people could represent a substantial increase in local population with resulting impact on the economy and available social services.

Table 8 lists factors that could have an effect on development at each prospect. The probable severity of these factors are also generally rated on a one-to-three scale with the ratings being defined in the notes on the page following. The ratings are entirely empirical and are of use only for relative evaluations. Environmental and social effects that have been judged to be minor or similar at all prospects have not been included. 
TABLE 8 - SUMMARY OF ENVIRONMENTAL AND SOCIO-ECONOMIC EFFECTS

\begin{tabular}{|c|c|c|c|}
\hline PROSPECT & $\begin{array}{c}\text { ENVIRONMENTAL } \\
\text { FACTORS } \\
\end{array}$ & CLASSIFICATION & $\begin{array}{l}\text { SOCIO-ECONOMIC } \\
\text { EFFECTS } \\
\end{array}$ \\
\hline Roosevelt & $\begin{array}{l}\text { Rare/endangered } \\
\text { species }\end{array}$ & 1 & 3 \\
\hline Beowawe & $\begin{array}{l}\text { Rare/endangered } \\
\text { species }\end{array}$ & 1 & - \\
\hline Coso Hot Springs & $\begin{array}{l}\text { Rare/endangered } \\
\text { species }\end{array}$ & 1 & 1 \\
\hline Long Valley & $\begin{array}{l}\text { Rare/endangered } \\
\text { species; } \\
\text { Aesthetics }\end{array}$ & $\begin{array}{l}2 \\
2\end{array}$ & $\begin{array}{l}- \\
3\end{array}$ \\
\hline $\begin{array}{l}\text { Brady's Hot } \\
\text { Springs }\end{array}$ & & - & 2 \\
\hline Steamboat Springs* & Aes thetics & 3 & 1 \\
\hline Clear Lake & $\begin{array}{l}\text { Water supply/quality } \\
\text { Aesthetics } \\
\text { Aquatic life }\end{array}$ & $\begin{array}{l}1 \\
3 \\
1\end{array}$ & $\bar{i}$ \\
\hline Surprise Valley & $\begin{array}{l}\text { Rare/endangered } \\
\text { species } \\
\text { Water supply/quality }\end{array}$ & $\begin{array}{l}2 \\
1\end{array}$ & $\begin{array}{l}2 \\
-\end{array}$ \\
\hline Fly Ranch/Gerlach* & $\begin{array}{l}\text { Rare/endangered } \\
\text { species }\end{array}$ & 2 & 2 \\
\hline Mountain Home & $\begin{array}{l}\text { Rare/endangered } \\
\text { species } \\
\text { Water supply/quality } \\
\text { Historic artifacts }\end{array}$ & $\begin{array}{l}1 \\
1 \\
1\end{array}$ & $\begin{array}{l}1 \\
- \\
-\end{array}$ \\
\hline Raft River & $\begin{array}{l}\text { Rare/endangered } \\
\text { species } \\
\text { Water supply/quality } \\
\text { Historic artifacts }\end{array}$ & $\begin{array}{l}1 \\
1 \\
1\end{array}$ & $\begin{array}{l}1 \\
- \\
-\end{array}$ \\
\hline Brigham City* & $\begin{array}{l}\text { Rare/endangered } \\
\text { species }\end{array}$ & 1 & 1 \\
\hline Chandler & Water supply/quality & 1 & 1 \\
\hline
\end{tabular}




\section{NOTES TO TABLE 8}

Environmental effects ratings:

- Rare/endangered species: 3 = individuals of the species inhabit the specific location. 2 = individuals of the species inhabit the general area. 1 = individuals of the species may pass through or may have been reported in the general area.

- Water supply/quality: 3 = water shortage exists. $2=$ - water shortage forecasted. 1 = some competition for available water.

- Aesthetics: 3 = readily visible development in a scenic and developed area. 2 = readily visible development in a scenic area. 1 = relatively hidden development in a scenic area.

- Artifacts: 2 = area of known historical/archeological significance, 1 = area of potential historical/ archeological significance.

Socio-economic effect ratings:

- 3 = development near urban area. 2 = development in county with large population. $1=$ development in county with small population. 
In general, it appears that all adverse environmental and socioeconomic effects can be mitigated by utilizing care in prospect development. 


\section{RANKING OF PROSPECTS}

Baseline geotechnical, socio-economic and environmental conditions at each of the 13 prospects are described in Appendix $D$.

The process of ranking the 13 prospects, by development potential, is based primarily on a comparative rating of prospects according to the most quantifiable factors. Other relatively minor and less quantifiable factors were used in particular cases to further separate close rankings obtained from the initial rating. In no case did the minor factors reverse the initial order.

The following conclusions were used for initial ordering:

- There are no first-order differences among prospects in the factors related to expected revenues from electric power production.

- Expected markets for direct use of heat from any one prospect are small compared with the prospect's potential and market for electric power, with the possible exceptions of Steamboat Springs, Brigham City, and Chandler.

- Major differences in administrative constraints and delays depend principally on a prospect being either in California or on Federal land or both.

- Development of most of the prospects can utilize part of the geothermal fluids for evaporative cooling, with reinjection of the bulk of produced fluids. Most prospects will rank roughly equally in terms of local water supply and quality. The possible exceptions are Mountain Home, where reinjection may not be required or desirable, and Brigham City and Chandler, where use of the high-salinity fluids for evaporative cooling may not be feasible. 


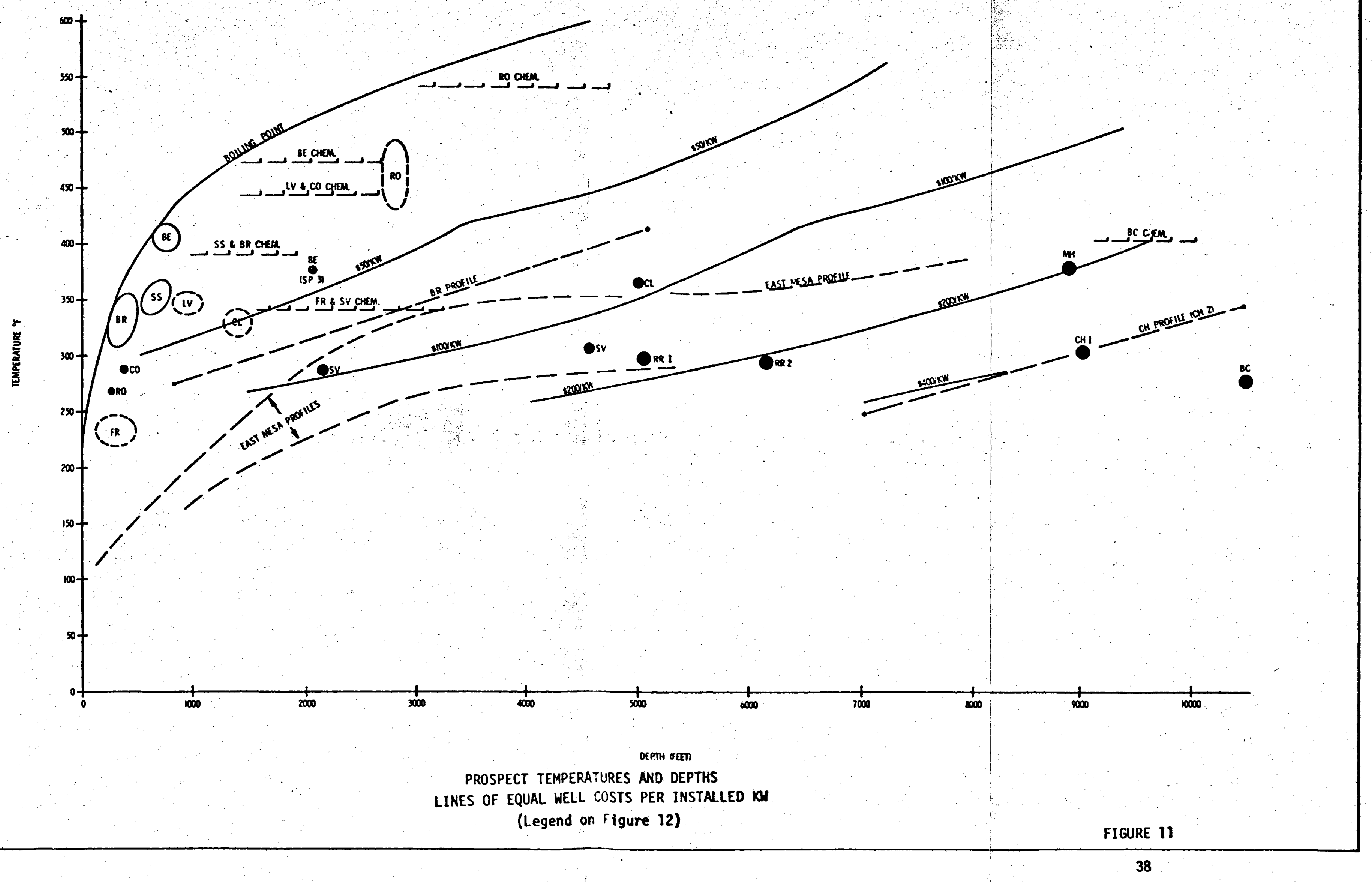


$\longrightarrow$ CHEMICAL ESTIMATE OF RESERVOIR TEMPERATURE

SINGLE WELL BOTTOM-HOLE TEMPERATURE

- - - SINGLE WELL TEMPERATURE PROFILE

1 SINGLE WELL WITH UNCERTAIN DEPTH AND TEMPERATURE

GROUP OF WELLS

PROSPECT LABELS

$$
\begin{aligned}
& \text { RO }=\text { ROOSEVELT } \\
& B E=\text { BEOWAWE } \\
& B R=\text { BRADY'S HOT SPRINGS } \\
& \text { SS }=\text { STEAMBOAT SPRINGS } \\
& L V=\text { LONG VALLEY } \\
& C O=\text { COSO HOT SPRINGS } \\
& \text { SV }=\text { SURPRISE VALLEY } \\
& \text { FR }=\text { FLY RAICH/GERLACH } \\
& C L=\text { CLEAR LAKE } \\
& \text { RR }=\text { RAFT RIVER } \\
& M H=\text { MOUNTAIN HOME } \\
& C H=\text { CHANDLER } \\
& B C=\text { BRIGHAM CITY }
\end{aligned}
$$

Figure 12 
- The environmental factor that would be most likely to cause cancellation or indefinite delay in development is the resistance to infringements on a scenic or popular recreational area.

The unit cost of producing energy is the single most important factor in ranking and ordering the prospects.

The generalized information on well costs and energy production rates provided previously in Figures 8 and 9 has been combined in Figure 11 where lines of equal well cost per gross KWe capacity as a function of temperature and depth are displayed. Figure 12 contains the legend for Figure 11. The indicated costs are nominal, derived from the centerlines of the ranges of well costs and energy production, in Figures 8 and 9, and assume a nominal flow rate of 1000 GPM per well. However, the lines of equal well cost per KWe have the same general slope regardless of the specific value attached to any line. The chart, then, provides a sequence which can be used to rank prospects. Bottom-hole temperatures, and, more importantly, temperature profiles from individual wells, are definite indicators of economic potential, even if the well does not have adequate proven flow. Chemical estimates of reservoir temperatures are full of uncertainties, but provide a rough upper limit to temperature increase with depth. This is particularly useful in prospects with single or shallow wells. Inexact as chemical temperatures are, prospect to prospect variations are greater than the expected statistical variation in any one determination; accordingly, chemical temperatures have been a decided help in the evaluation process.

The present state of information on the prospects does not permit discrimination on the basis of reservoir life, well flow rates, or variations in well cost. Few, if any, of the existing exploratory wells are likely to be satisfactory production wells. Many of the shallow wells that had good initial flows have declined since, and few deep wells have flowed as much as $1000 \mathrm{GPM}$. The varying results of drilling step-out wells after further exploration at different sites, and of stimulating marginal wells, are not predictable now. 
Nominal well and plant costs for each prospect have been determined from the cost data contained in Section 3.2 above. From these, nominal unit costs can be found and, then, the unit cost (and 200 MWe generating cost) differences between prospects can be determined. These costs and cost differences, indicated in Table 9, permit ranking and approximate rating of the selected prospects on the basis of expected nominal unit energy costs.

The well costs of Table 9 consider a flow rate of 650 GPM (probably a more reasonable figure than the 1000 GPM usually assumed) and a one-toone ratio of injection/spare wells to producing wells. Accordingly, Table 9 well costs are a factor of three greater than those of Figure 8 .

It should be emphasized that these nominal costs are not estimates of the total development cost for the individual prospects in that some costs common to all prospects have not been included. Further, most of the included costs are now generally only predictable, and should not be considered specific for a prospect. The only significance and use of these nominal unit costs lies in the prospect-to-prospect relationships. The prospects are listed in Table 9 in order of decreasing nominal unit cost; this comprises the initial ranking of the prospects by development potential.

The cost differences in Table 9 allow weighing the comparative effects of other factors on the final ranking. This permits a semi-quantitative decision on whether, for example, Coso Hot Springs and Long Valley rank higher than Brady's Hot Springs and Steamboat Springs, given the greater administrative constraints expected in California. The unit cost difference between these two pairs of prospects is $\$ 45 / \mathrm{KWe}$, equivalent to $\$ 9$ million for a 200 Mhe development. This is approximately the cost of tying up an investment of $\$ 50$ million for two years. Since an informed and objective investor would most probably not commit to an investment of that size in advance of administrative clearance, it appears that the difference in expected unit costs outweighs the effect of delays. The deferral of expenditures and income results in a reduction of present cash 


\section{TABLE 9 - NOMINAL COST AND COST DIFFERENCES}

Cost

Differe

Nominal Nominal Nominal Nominal Unit Cost (200 Wh
emperature Well Cost Plant Cost Unit Cost Difference

$\begin{array}{lllll}\left({ }^{\circ} \mathrm{F}\right) & (\$ / \mathrm{KWe}) & (\$ / \mathrm{KWe}) & (\$ / \mathrm{KWe}) & \begin{array}{c}\text { Difference } \\ (\$ / \mathrm{KWe})\end{array} \\ (\$ \times 106)\end{array}$

Rooseve1t

450

100

$<300$

$<400$

Beowawe

440

100

$<320$

20

$<420$

Coso Hot Springs

420

125

330

455

Long Valley

400

Brady's Hot Springs

Steamboat Springs

150

350

350

200

400

Clear Lake

325

Surprise Valley

Fly Ranch/Gerlach

250

425

75

675

Mountain Home

350

$300 *$

400

25

15

Raft River

300

300

450

50

750

Brigham City

325

600

425

275

1025

Chandler

325

1200

425

1625

600

* no reinjection 
value of the expected profits, but normal investment strategy is to improve this situation by merely waiting, while spending reasonable sums to minimize delays.

The initial ranking of Table 9 shows several close prospect pairs where expected unit costs are approximately equal given the uncertainties in the data. Table 10 lists significant differences between prospects in a pair and includes an indication of the degree of uncertainty in the data. The pluses and minuses in this table are not quantified, but can be weighed qualitatively in terms of the normal strategy of earthresource investors.

All of these prospects need further exploratory drilling to establish depth, fluid temperature, and flow rates from actual production wells, or to locate productive zones. Accordingly, Coso Hot Springs is ranked ahead of Long Valley, and Brigham City is ranked ahead of Chandler, because of higher exploration potential. Brady's Hot Springs is ranked ahead of Steamboat Springs, and Surprise Valley ahead of Fly Ranch/Gerlach because better information on exploratory potential is available.

The environmental factors in Table 10 lead to the same differentiation between close pairs. Long valley lies in a much-used mountain recreational area, while Steamboat Springs lies in the midst of new residential developments. Development of the geothermal resource in either area will clearly and visibly impinge on the interests of large numbers of people. Coso and Brady's Hot Springs, by contrast, are in isolated desert areas where development will affect only small local populations. The desert environments are fragile, but the care that is now required from developers can effectively keep the adverse effects to a minimum.

The initial rank order of Table 9, with the close pairs separated, provides the final prospect ranking of Table 1. 


\section{TABLE 10 - PROSPECT PAIR DIFFERENCES}

\begin{tabular}{|c|c|c|c|}
\hline Long Valiey & & & Coso Hot Springs \\
\hline $\begin{array}{l}\text { Popular mountain recreation } \\
\text { area. }\end{array}$ & - & + & Nearly uninhabited desert. \\
\hline $\begin{array}{l}\text { Surface water available for } \\
\text { exchange cooling, perhaps } \\
\text { evaporative cooling. }\end{array}$ & + & - & Very little surface water. \\
\hline & & + & $\begin{array}{l}\text { U.S. Navy controls land, probably } \\
\text { speeding development. }\end{array}$ \\
\hline $\begin{array}{l}\text { Several wells }>1000^{\prime} \text {, with } \\
\text { temperature, flow, and } \\
\text { chemistry. }\end{array}$ & + & - & $\begin{array}{l}\text { One } 375^{\prime} \text { well only but slimhole } \\
\text { exploratory well expected in } \\
\text { 1975. }\end{array}$ \\
\hline & & + & $\begin{array}{l}\text { Possible indicator of dry } \\
\text { steam from seismic data. }\end{array}$ \\
\hline Brady's Hot Springs & & & Steamboat Springs \\
\hline $\begin{array}{l}\text { Isolated desert area, } \\
\text { traversed by highway and } \\
\text { power line. }\end{array}$ & + & - & Suburban setting. \\
\hline $\begin{array}{l}\text { No local market for direct } \\
\text { or waste heat. }\end{array}$ & - & + & $\begin{array}{l}\text { Small market for direct or } \\
\text { waste heat. }\end{array}$ \\
\hline $\begin{array}{l}\text { Deep-well proof of temp. } \\
>400^{\circ} \mathrm{F} \text {. }\end{array}$ & + & & \\
\hline Surprise Valley & & & Fly Ranch \\
\hline Several deep wells. & + & - & $\begin{array}{l}\text { No deep wells, no proven } \\
\text { temperature }>250^{\circ} \mathrm{F} \text {. }\end{array}$ \\
\hline $\begin{array}{l}\text { Subject to California strict } \\
\text { regulations. }\end{array}$ & - & + & $\begin{array}{l}\text { Subject to Nevada easy } \\
\text { regulations. }\end{array}$ \\
\hline Brigham City & & & Chandler \\
\hline $\begin{array}{l}\text { Geologic indications of higher } \\
\text { temperature and shallower } \\
\text { reservoir than Chandler. }\end{array}$ & + & + & $\begin{array}{l}\text { Higher proven temperature than } \\
\text { Brigham City. } \\
\text { Indicator of high flow rates } \\
\text { rates from subsequent wells. }\end{array}$ \\
\hline
\end{tabular}




\section{REFERENCES}

1. Experimental Geothermal Research Facilities Study (Phase 0); TRW Final Report No. 26405-6001-RU-00, December 1974.

2. Western Systems Coordinating Council: Reply to Federal Power Commission Docket R-362, Reliability and Adequacy of Electric Service, Order No. 383-3; Apri 1, 1975.

3. Proceedings of the United Nations Symposium on the Development and Utilization of Geothermal Resources; Geothermics Special Issue 2, 1970. 


\section{APPENDIX A \\ GEOTECHNICAL AND RESOURCE UTILIZATION}

This appendix contains a general discussion of geotechnical and resource utilization considerations that form a background for identifying and ranking the geothermal prospects. The discussion is by no means definitive but only sets the stage for the more specific discussions in other parts of this report.

\section{Al Geotechnical}

While the various geotechnical topics are discussed individually below, it should be recognized that it is often the overall assemblage of information that is significant. As an example, in geothermal exploration, heat flow mapping is the nearest thing to a diagnostic prospecting method, but this indicator is not clear-cut and sure by itself. The convergence of several lines of evidence, particularly high heat flow, low resistivity, and high geochemical temperatures in any waters that may be available, are much more useful in locating, delineating and evaluating a geothermal prospect.

\section{A1.1 Regional Geology}

The geothermal resources of the contiguous United States that can be developed by current technology are concentrated in the eleven states lying west of the Great Plains. Within this region, the resources are even more highly concentrated in three geologic provinces, the Basin and Range, the Northwestern Volcanics, and the province of shear faulting in California south and west of the Sierra Nevadas. There is a good geological reason for this concentration, since the earth's crust in all three provinces has been highly disrupted by through-going faults, active at various times from about twenty million years ago to the present. In the Basin and Range and Volcanic provinces, the crust has been cracked and thinned by east-west stretching, while in California the crust has been greatly sheared by continuing right-lateral movements. Both types of motion have opened and 
maintained channels for mobile hot rock to rise within the crust to levels where it can supply heat to circulating groundwater. In favored places the circulation of water carries heat still further upward, to provide geothermal resources within reasonable drilling depth.

The three provinces are shown on the tectonic map of Figure $A-1$ (Ref. A-1): The figure also shows the location and geological setting of each of the 13 prospects of interest here.

The Basin and Range province is made up of many long narrow northtrending mountain ranges separated by valleys that are deeply filled with alluvium washed down from the mountains. The underlying cause of this topography is shown in the schematic section of Figure A-2a.

Regional tension has produced many normal faults, dipping steeply toward the downthrown sides, across the width of the whole province, dividing the region into blocks that have tilted, or moved up or down, relative to their neighbors. Erosion of rising blocks, or the rising edges of tilted blocks, has occurred simultaneously with vertical motion along the faults, so that most of the faults are now covered with alluvium, and many of them lie some distance toward the valley centers from the visible edges of the ranges. The rocks exposed on the ranges are partly a variety of rocks older than Tertiary, and partly Tertiary volcanics erupted before and during the early stages of normal faulting. Large areas of volcanics appear mostly around the boundaries of the province, except at the contact with the west side of the Rockies along the Wasatch Front in northern Utah and southern Wyoming. The alluvium of the valleys comes directly from erosion of the neighboring ranges, with some interbedded volcanics, and may be over 10,000 feet thick in some valleys, semi-consolidated at depth, and generally unconsolidated near the surface, except where cemented by caliche.

The whole province is famous for its present aridity, but was much ' wetter 10,000 years ago, and is still well supplied with fossil groundwater. Surface water is seasonal, depending mainly on the winter snowfall on the ranges. Water table depths now range from tens to several hundreds of feet below the surface. In the northern part of the province, the overall drainage is internal, so that saline groundwater, at depth and in the centers 


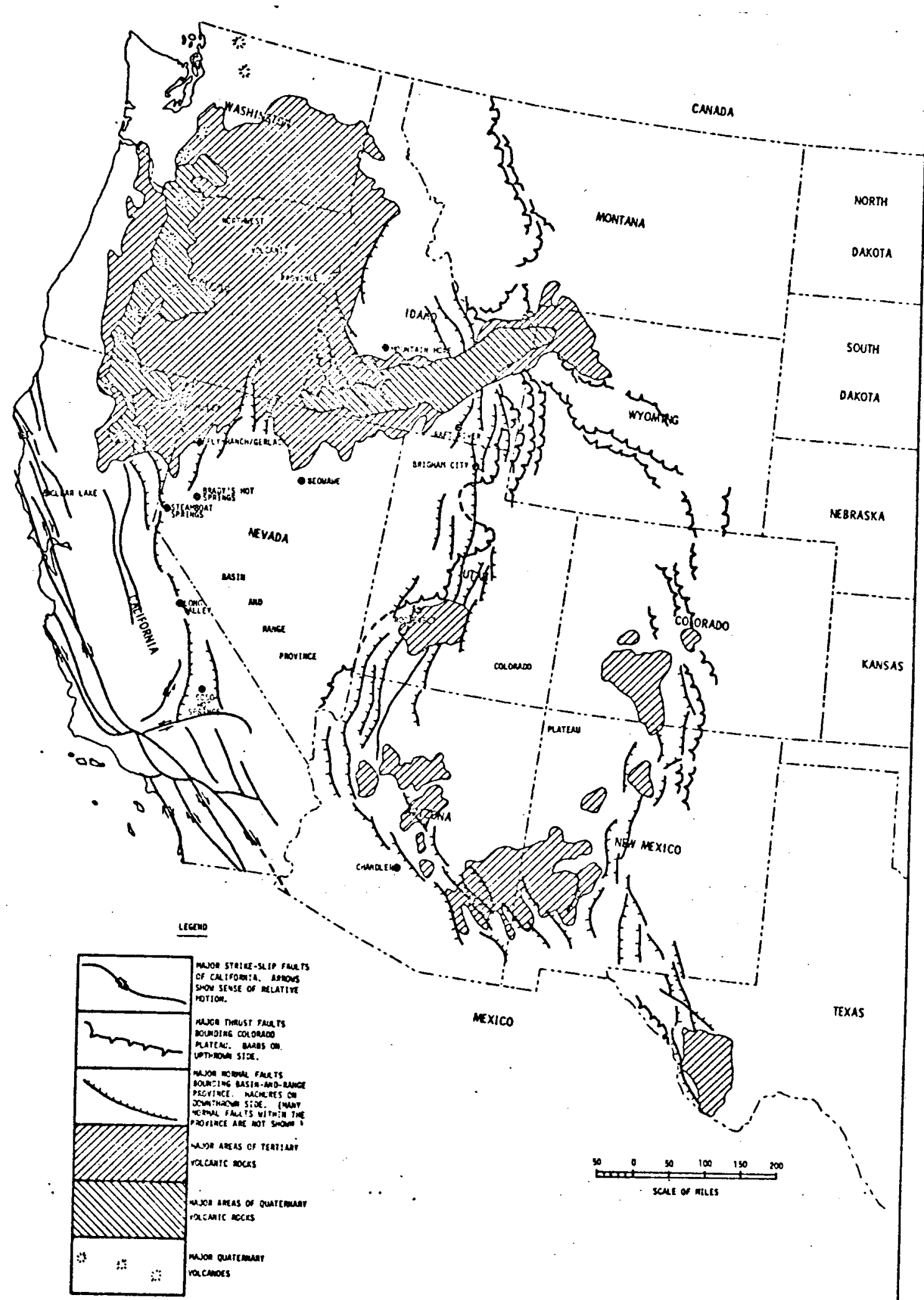

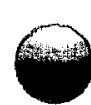




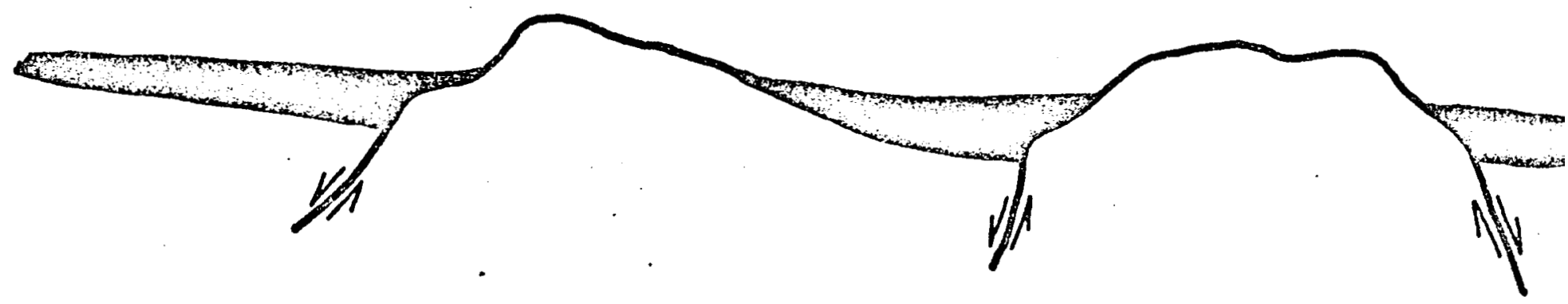

SCHEMATIC SECTION - BASIN AND RANGE PROVINCE

FIGURE $\quad A-2 a$

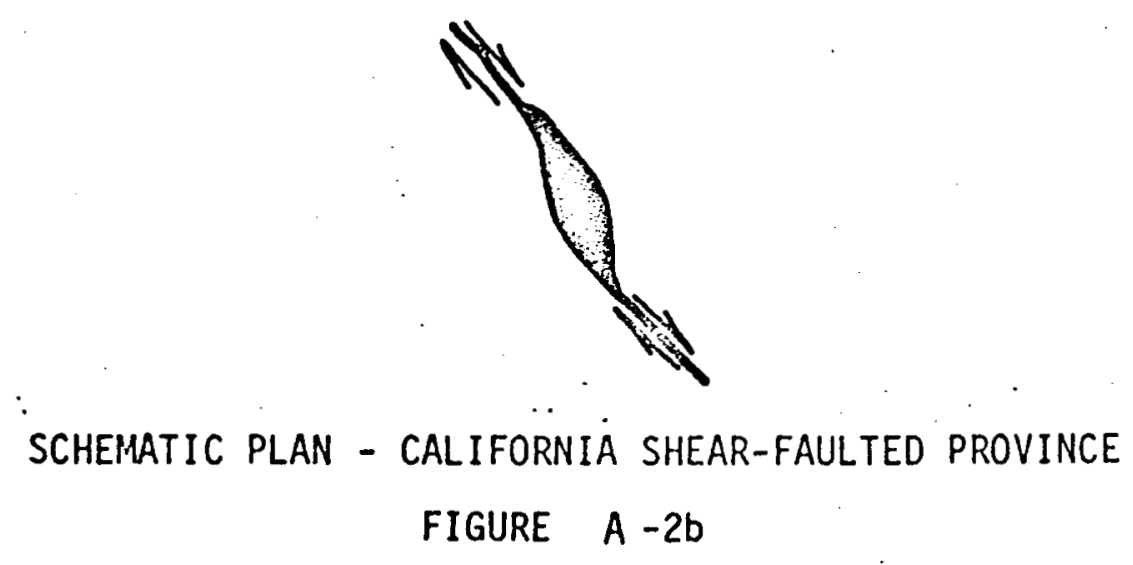


of the valleys, is common, but not universal. The southern part is generally drained by the Rio Grande and Colorado River systems, but some individual valleys have no exterior drainage.

The valley sediments may have high porosity and permeability to great depths, and so can act as reservoirs within which groundwater is heated at depth, probably most often where normal faults contact the alluvium. The groundwater then brings heat nearer the surface by convective circulation combined with any overall flow pattern that exists. In such sedimentary reservoirs, intergranular flow may be at least as important as flow in fracture systems, and the reservoir itself may be a compact body of hot pore water that is easier to locate and tap than the flows in elusive fracture systems.

The Northwestern Volcanic province is largely covered with lava flows some thousands of feet thick. The oldest flows (up to 20 million years old) are the Columbia River Basalts, which erupted in enormous volume, essentially drowning most of the crustal rocks. Younger volcanic rocks have erupted within the last one million years along the Cascade Range and along the Snake River Plains that run northeastward through southern Idaho to Yellowstone Park. These younger volcanics are more varied and complex than the Columbia basalts, coming from volcanic centers as well as fissures, more silicic (i.e., contaminated with crustal rocks), including tuffs and ashfalls as well as lavas, and often interbedded with sediments.

The normal faulting of the Basin and Range province extends well into the Volcanic province to the north, and is probably related to the fissures from which the Columbia basalts erupted. It is likely, in fact, that the whole volcanic province results from a more extreme form of the east-west stretching that fractured the Basin and Range.

Volcanic terrains, and basalt flows particularly, are usually highly permeable to groundwater flow, but the permeability is concentrated in fractures, vesicular zones, and weathered zones between beds. Most of the province east of the Cascades has little rainfall, but is very liberally supplied with groundwater by runoff from surrounding mountains. 


\section{A.1.1.1 Acidic Volcanics}

In any of the geologic settings that favor geothermal occurrences, localized "hot spots" may occur that are specifically associated with young, acidic volcanic rocks or caldera structures, or both. Acidic volcanics, unlike the more common basalts, have compositions similar to common intrusive igneous rocks. Probably the acidics are most often generated by the melting of crustal rocks, in contrast to basalts, which are believed to erupt from sources at or below the bottom of the crust. Acidic lavas are far more viscous than basalts at any temperature, and consequently erupt more explosively; basalts can flow freely through comparatively narrow channels to the surface. For this reason, the caldera structures resulting from collapse of volcanic centers after explosive eruptions are usually associated with acidic volcanics. Yellowstone National Park and Long Valley are notable examples of geothermal accumulations associated with this type of structure.

The Snake River, for example, flows in a canyon of volcanic rocks whose walls feed the river with a great volume of springwater from subsurface flows. The main problem in geothermal development in this province is to locate hot water beneath the large flows of cold water nearer the surface. In general, this cold water will dilute shallow hot water; there are many hot springs in the region, but not many very hot springs. This regional picture shows good prospects for widespread use of shallow, moderately hot water for industrial and space heating, when sources and markets can be brought together.

The shear-faulted province of California has been disrupted by a continuing overall shear, in which the coastal region has moved hundreds of miles northwest relative to the inland parts. The vertical faults along which this motion has taken place, typified by the San Andreas fault system, are deep and fundamental, marking the boundary zone between two major crustal plates in relative motion. At any place where a faultplane in this system takes a local lateral jog, the crust is in tension, and can open to make a channel for intrusion of hot rack from beneath, Figure A-2b. This picture is highly simplified and schematic, but probably is 
the central reason for the scattered occurrence of major geothermal resources in California south and west of the Sierra Nevada. At the southern end of the state, extending into the Gulf of California, lies the large geothermal area of the Imperial-Mexicali Valley, with one producing field in Mexico, four fields in various stages of development in the United States, and others being explored. The whole area is a deep sedimentary basin filled with ten to twenty thousand feet of deltaic sediments of the Colorado River. Five hundred miles to the northwest lies the Geysers, the world's largest producing geothermal field, in an entirely different geological setting of Mesozoic metamorphic rocks intruded by young volcanics. In the province as a whole, the location and characteristics of geothermal resources are more difficult to generalize than the other two provinces, since the local character of the fault system will depend much more on the varied, adjacent rocks and structures.

\section{A1.2 Thermal Spring Distribution}

The existence of thermal springs (including fumaroles, geysers and other surface displays of hot water and gases) is a prime indication of excess subsurface heat. At the present state of the geothermal exploration art, thermal springs are the principal means of defining geothermally interesting areas. This situation is directly analogous to the early part of the century when petroleum exploration was in its infancy and interesting areas were defined (and many large discoveries made) on the basis of surface oil and gas seeps. Prior to about 1970, exploration for geothermal resources largely consisted of drilling in the neighborhood of thermal springs, usually trying to intersect fault planes at depth and tap conduits of hot ground water.

A thermal spring is commonly defined as containing water with an average temperature at least $15^{\circ} \mathrm{F}$ higher than the mean annual air temperature at the locality. Figure $A-3$ shows the thermal spring distribution in the western United States (Ref. A-2). Note that the distribution is generally confined to the three geologic provinces described above. 
R $0-75-27$,
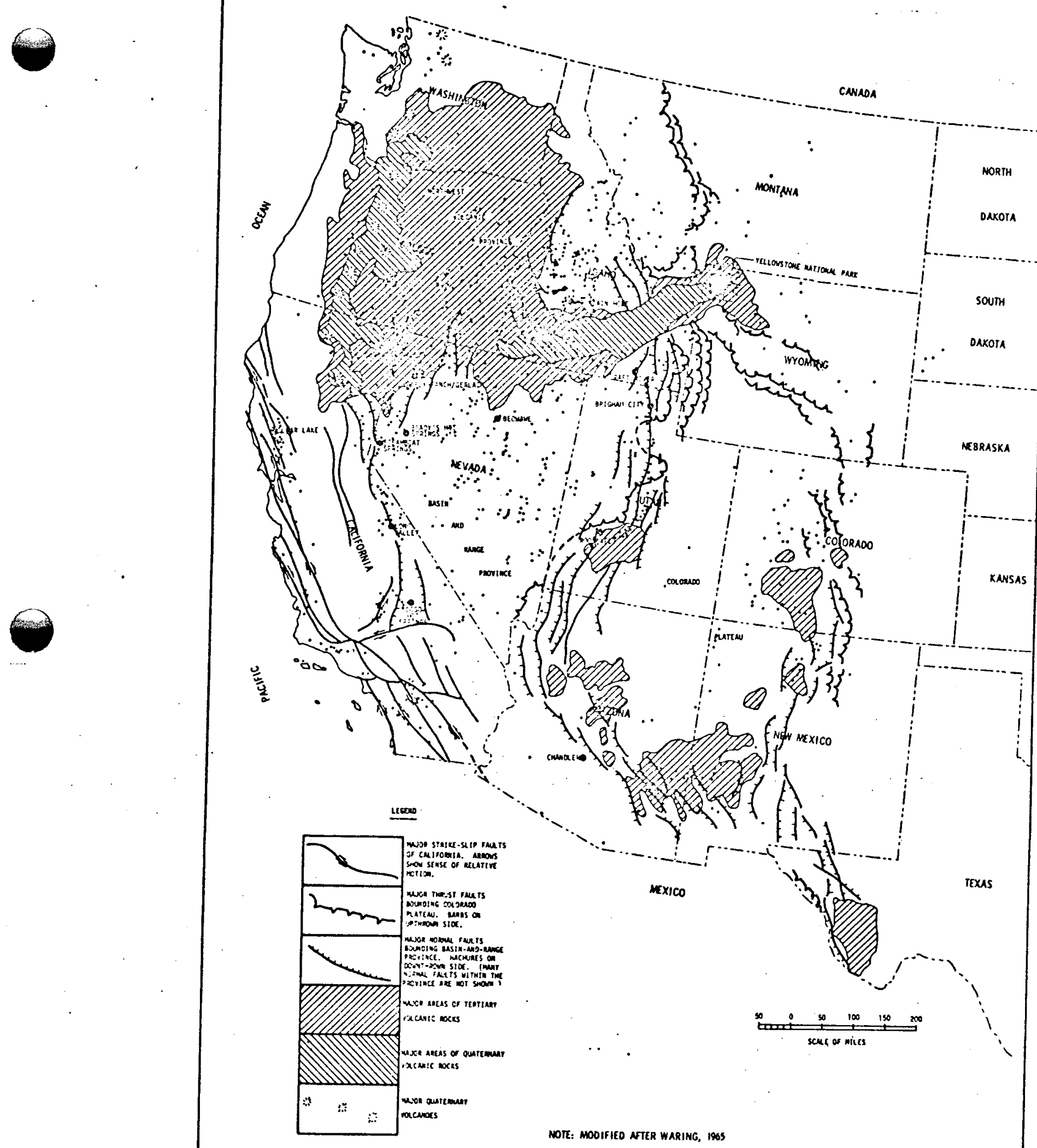

6

THERMAL SPRING DISTRIBUTION IN THE WESTERN UNITED STATES

FIGURE $A-3$ 


\section{A1.3 Geophysical Techniques Related to Geothermal Exploration}

Currently available geophysical methods, developed primarily for petroleum and mineral exploration, vary in usefulness as geothermal prospecting tools.

The method available that is specific for geothermal resources is that of measuring heat flow in the subsurface. Heat flow in this application is the product of the temperature gradient across a subsurface interval and the thermal conductivity of the rock in the same interval. Heat flow is usually measured in slim holes, desirably a few hundred feet in depth. Hole depth is a compromise between cost and the desire to approach the geothermal reservoir as closely as possible and to avoid the very near surface where the data is often distorted. Successful use of this method involves extrapolating the relatively shallow data to the deeper depth of the geothermal reservoir. Heat flow has been very successfully used in the Imperial Valley, California, and is becoming more used in other areas.

Another promising exploration method utilizes electrical techniques. A buried mass of water that is unusually hot or salty (or both) will have an unusually low electrical resistivity in that the resistivity of water decreases markedly with both temperature and salinity. The subsurface resistivity can be measured either directly, by injecting current into the ground and measuring the potential drop in an appropriate manner, or by electromagnetic techniques. These involve inducing currents in the subsurface and measuring the resultant distortion in the magnetic field in an appropriate manner. Variations of this technique make use of currents naturally induced in the earth by fluctuations in the earth's magnetic field or by atmospheric discharges. Audio-magnetotelluric measurements are of this latter type and are made in the 1 to $1000 \mathrm{~Hz}$ band. Another technique, the self-potential method, measures natural earth currents directly and can be of qualitative use in determining subsurface conditions.

Passive seismic techniques also appear promising. Micro-earthquakes often occur in swarms centering near geothermal areas, a geologically reasonable happening in that the magmatic heat sources that are necessary for the existence of geothermal resources are young in age and are generally associated with tectonically active areas. Hypocenter locations obtained 
from individual microquakes indicate shallow depth and this is consistent with the expected shallow depth of the heat sources. Hypocenter locations have been used successfully in defining specific geothermal prospects as evidenced by the East Mesa field in California. Hypocenter data might also provide information on the areal and vertical distribution of the geothermal water and on the location of faults that act as conduits for the hot waters from depth. In addition to micro-earthquakes, areas of high seismic surface noise at specific frequencies of a few $\mathrm{Hz}$ have been correlated to geothermal areas.

Refraction seismology and gravity and magnetic methods, particularly when used in conjunction, will provide regional structural information such as the depth of sedimentary basins and the locations of buried faults. More detailed structural data can be obtained by reflection seismograph techniques.

\section{A1.4 Geochemical Techniques Related to Geothermal}

The dissolved solid and noncondensible gas content of geothermal fluids is significant from an engineering, environmental and geotechnical standpoint. Should the dissolved solid, ordinarily expressed as total dissolved solids (TDS) in parts per million (ppm) by weight, or gas content be high, corrosion and scaling in the energy extraction system can present formidable problems. The Niland area of the Imperial Valley with a TDS of about 300,000 is the most extreme example of this. Should the dissolved solid and gas content be very low and particularly if the water is potable (TDS <1000), the water can be valuable for agricultural or consumption purposes. Further, surface subsidence and reservoir pressure maintenance permitting, such water need not be reinjected into the subsurface, resulting in a more inexpensive energy extraction system.

Modern geochemical techniques utilize the amounts of silica, calcium, sodium and potassium in metastable solution as well as the ratios of certain isotopes to estimate the maximum temperature to which the water has at one time been heated. This "chemical temperature" might represent the ultimate maximum temperature that is available in the geothermal reservoir. 


\section{A1.5 Geothermal Reservoir Characteristics}

Most geothermal energy extraction systems now defined are based upon a minimum fluid flow rate of 1000 gallons per minute (GPM) per well. The flow rate and ultimate life of the resource ( 30 years is generally desired for capital amortization purposes) is a function of many subsurface reservoir characteristics, principal of which are areal and vertical extent, porosity, permeability and the rate of heat recharge.

Geothermal reservoirs are of two types, interstitial and fracture, and a specific reservoir may contain both. Interstitial reservoirs deliver water that is contained in pore spaces in the rock; the Imperial Valley of California presents a prime example of this type.

Fracture reservoirs deliver water through open fractures in the rock and sustained flow requires a network of interconnecting fractures. Where fractures are available, the flow per foot of reservoir thickness is likely to be much greater than interstitial reservoirs.

There are several reasons for a well not delivering sufficient flow, and many of them are curable. Drilling the hole itself may adversely affect the reservoir adjacent to the bore (by mud invading the formation, for instance), or the well may have been cased or completed in a faulty manner. In a fracture reservoir, the well may simply not have encountered any fractures. Many well stimulation techniques, such as hydraulic and explosive fracturing, are available to improve oil-well flows, and their adaptation to hot wells will be important for developing geothermal resources. In many cases a new well nearby, perhaps differently engineered, will achieve the desired flow.

\section{A2 Resource Utilization}

The geothermal resource of highest quality is dry steam. Those that are known tap steam at about $465^{\circ} \mathrm{F}$ and 500 psia static temperature and pressure, the conditions of maximum enthalpy (available energy) for steam in contact with liquid water. The simplest way of producing power is to pass the steam through noncondensing turbines, exhausting at atmospheric 
temperature and pressure. This has the lowest capital costs, but wastes about one half the mechanical energy available in the steam. Further; noxious gas in the steam may be vented to the atmosphere. The common alternative is to use condensing turbines, exhausting at the vapor pressure of lukewarm water $\left(80-100^{\circ} \mathrm{F}\right)$ to condensers where the steam is cooled and condensed by heat exchange or (usually) direct contact with cooling water. The condensed steam itself can be re-evaporated in cooling towers to cool this water. Non-condensible gases must be pumped out of the condenser to keep the pressure low, so that noxious gases can be collected for treatment or disposal.

Dry steam is rare. It is far more common for geothermal wells to encounter liquid water underground, at temperatures below the boiling point that corresponds to the pressure of the water, which is usually close to hydrostatic pressure. Depending on the temperature, pressure, permeability, and depth of the producing horizon, some hot water wells may supply a spontaneous flow of boiling water and steam, lifted by the boiling of the water.

Depending on temperature, a hot water well can flash a fraction of steam at a suitable turbine inlet pressure, ranging from about $15 \%$ at $450^{\circ} \mathrm{F}$ down to none at about $300^{\circ} \mathrm{F}$. The most practical and economical way to utilize the hotter wells is to flash at the wellhead, separate the steam from the water, and deliver the steam to a condensing turbine. All thermodynamic processes are more efficient, though not necessarily less expensive, if small steps are involved, so the separated water may be flashed again, and perhaps again to lower pressures and delivered to lower pressure turbines or stages.

At temperatures below approximately $420^{\circ} \mathrm{F}$, another system appears more economical in extracting the heat energy of the hot water. This is a socalled binary system, in which the hot water, with or without steam, supplies heat through a heat exchanger to vaporize a suitable second working fluid, such as isopentane, in a closed system of boiler, turbine, condenser, and feed pump. This system can have advantages in using more saline, as well as cooler, fluids, since the fluid remains liquid under pressure at all times, and deposition of solids at the expansion stage is avoided. 0ther developing systems for dealing with cooler or saltier fluids, such as the 
"total-flow" system, or the helical expander, are essentially rugged or self-cleaning water turbines adopted to convert the energy of the expanding steam fraction of the fluids. 
A-1 United States Geological Survey: The National Atlas, 1967

A-2 Waring, G.A.: Thermal Springs of the United States and Other Countries of the World, United States Geological Survey Professional Paper 492, 1965 


\title{
APPENDIX.B \\ ADMINISTRATIVE REQUIREMENTS
}

\begin{abstract}
Administrative requirements pose substantial political, legal, institutional and socio-economic impediments to developers of geothermal resources. These requirements consist of various regulations and permit procedures that vary significantly with state and county, and with Federal, state or private land cwnership. The most complex series of procedures are found in development on Federal lands and usually the interaction of regulatory authority between Federal, state and county levels of government is required. This appendix provides a summary of these administrative requirements as applied sequentially to geothermal land leasing, exploration, development and production.
\end{abstract}

\section{Bl State or Private Lands}

The regulatory requirements for development of geothermal resources on state or private lands are generally identical, with the exception of the leasing procedures. Figure B-1 illustrates schematically the sequential administrative requirements for geothermal activities on state or. private lands in California. The California procedures and regulations are the most stringent in the nation. These tough requirements stem mainly from the California Environmental Quality Act which insures that all local governments control new development in a manner consistent with the policy guidelines (environmental goals) of the Act. All proposed projects, public or private, which are judged to offer potential significant impact to the environment; may not be implemented without preparation and evaluation of an Environmental Impact Report (EIR). The local (county) governments are the responsible agency in issuing the requirement for an EIR, and participate jointly with numerous state and local agencies in the approval of a proposed project. In other states, such as Nevada, Arizona, Utah and Idaho, environmental impact reports are not required by either local or state authorities and approval of a proposed geothermal project is accomplished by relatively simple processes. 


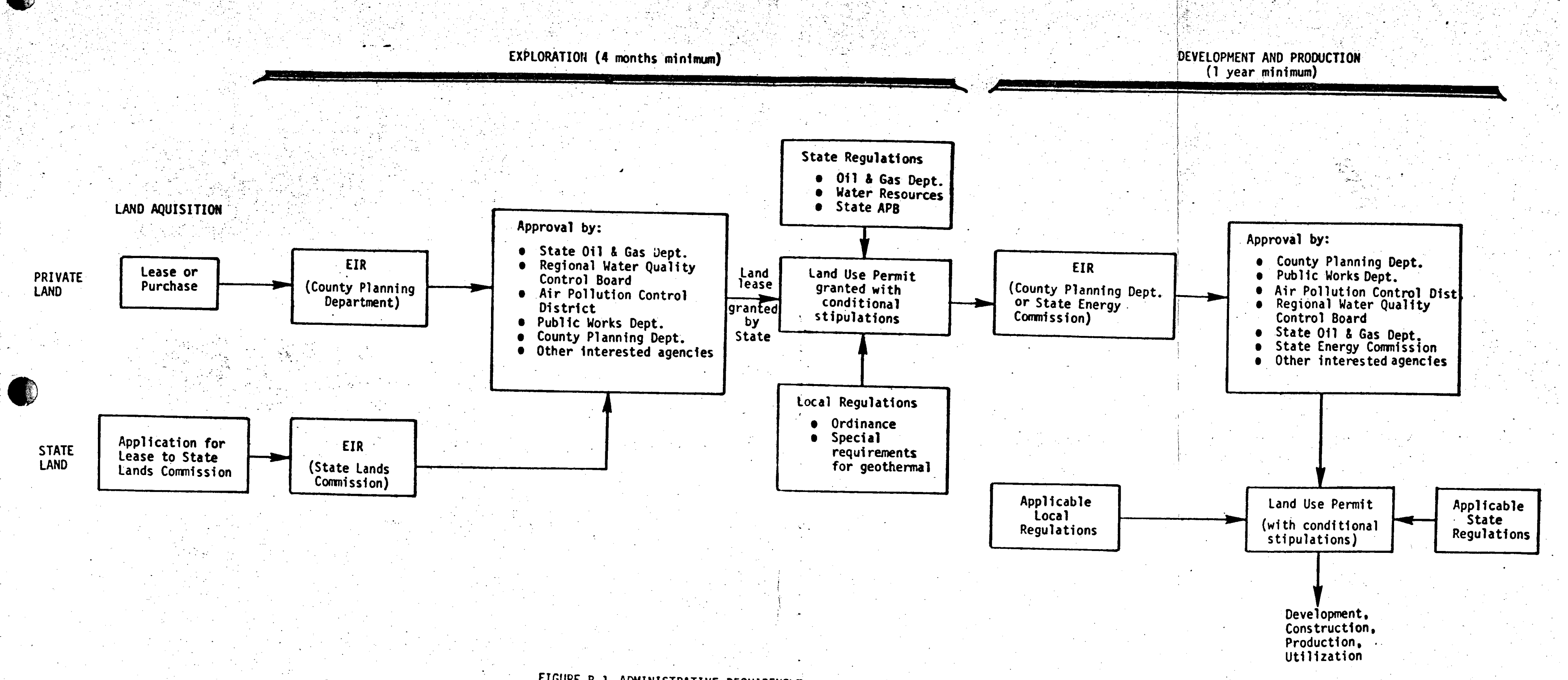
FIGURE B-1 ADMINISTRATIVE REQUIREMENTS FOR DEVELOPMENT OF GEOTHERMAL RESOURCES ON
STATE OR PRIVATE LAND IN CALIFORNIA 
The administrative requirements for exploration, development and production are discussed below. Distinctions from state to state are as noted.

\section{B1.1 Exploration}

Acquisition of state lands may precede or follow exploratory drilling. In California, a prospecting permit issued by the State Lands Commission permits a developer to explore on state lands without lease or purchase. Similar permits are obtainable in other states. However, in exploration, a developer is subject to nearly the same administrative requirements whether committed to lease or to prospect rights. Prospecting without a lease (but under the same administrative requirements) may also be conducted on private lands by negotiation between owner and operator.

In California, geothermal exploration on state or private lands may not proceed without the preparation and evaluation of an EIR on the proposed activities. When the proposed project is on private land, the county is responsible for the preparation of the EIR. When the project is on state land, the State Lands Commission prepares the EIR before approving a land lease. In either case, the EIR is reviewed by several state and local agencies and public hearings are held before approval may be issued by the state for a drilling permit, and by the county for a land use permit. The permits are subject to the regulations of the numerous interested agencies. The EIR, review and approval cycle may require a minimum of approximately four months but often requires longer periods depending on the controversy generated at the hearings. Multiple public hearings may be required and these may occur serially causing very long delays.

Exploration in Nevada, Utah, Arizona and Idaho may require use permits issued by counties and drilling permits are generally required by the state geothermal regulatory agency. Table B-1 outlines the agencies involved in the respective states. In Idaho and Utah, the water resources departments have the authority to control geothermal exploration. Before public hearings, these agencies are the sole authority for review of drilling permit application. The drilling regulations in Idaho and Utah are similar 
TABLE B-1

ADMINISTRATIVE REQUIREMENTS FOR DEVELOPMENT OF GEOTHERMAL RESOURCES ON STATE OR PRIVATE LAND

\begin{tabular}{|c|c|c|c|c|c|}
\hline \multirow[b]{2}{*}{ STATE } & \multicolumn{2}{|l|}{ EXPLORATION } & \multicolumn{3}{|c|}{ DEVELOPMENT and PRODUCTION } \\
\hline & PROCEDURE & $\begin{array}{l}\text { REGULATIONS } \\
\text { (or Regulatory Agencies) }\end{array}$ & PROCERURE & $\begin{array}{c}\text { REGULATIONS } \\
\text { (or Regulatory Agencies) }\end{array}$ & $\begin{array}{c}\text { NEW REGULATIONS TO } \\
\text { BE PROMLULGATED }\end{array}$ \\
\hline Eâtifomia & $\begin{array}{l}\text { EIR required by County, review } \\
\text { by several agencies: } \\
\text { - State Oil \& Gas Dept. } \\
\text { - Regionai Water Cuality Board } \\
\text { - Air Pollution Control Board } \\
\text { - Local Planning Cept. } \\
\text { - Other interested agencies } \\
\text { Drilling permit by Oil \& Gas } \\
\text { Dept. Land use permit by } \\
\text { county. }\end{array}$ & $\begin{array}{l}\text { Applicable county regula- } \\
\text { tions. } \\
\text { State } 0 \text { il \& Gas Dept. } \\
\text { Regional Water Quality } \\
\text { Board. } \\
\text { Air Pollution Control } \\
\text { Board. }\end{array}$ & $\begin{array}{l}\text { EIR required by county, review } \\
\text { by several agencies: } \\
\text { - State 0i\} \& Gas Dept. } \\
\text { - Regional Water Quality Board } \\
\text { - Air Pollution Control Board } \\
\text { - State Energy Comission } \\
\text { Orill ing permit ry } 0 \text { il \& Gas } \\
\text { Dept. Land use permit by } \\
\text { county. }\end{array}$ & $\begin{array}{l}\text { Applicable county regu- } \\
\text { lations. } \\
\text { State 0il \& Gas Dept. } \\
\text { Reglonal Water Quality } \\
\text { Board. } \\
\text { Air Pollution Control } \\
\text { Board. } \\
\text { Public Utilities } \\
\text { Commission. }\end{array}$ & None immediate \\
\hline Arizona & $\begin{array}{l}\text { Drilling permit. 0il \& Gas } \\
\text { Commission is sole authority. }\end{array}$ & $\begin{array}{l}\text { 0il \& Gas Commission } \\
\text { regulations. } \\
\text { Applicable county regula- } \\
\text { tions. }\end{array}$ & $\begin{array}{l}\text { State Lands Dept. approves siting } \\
\text { of power plant on state lands. } \\
\text { No siting authority exists for } \\
\text { private land. } \\
\text { Orilling permit by 0il \& Gas } \\
\text { Comission. }\end{array}$ & $\begin{array}{l}\text { Applicable county regu- } \\
\text { lations. } \\
\text { State Power Authority. } \\
\text { 011 \& Gas Commission } \\
\text { regulations. }\end{array}$ & Mone imediate \\
\hline Nevada & $\begin{array}{l}\text { Land use permit by County } \\
\text { Plannir.g Dept. } \\
\text { Orill permit required only } 15 \\
\text { designated basins. }\end{array}$ & $\begin{array}{l}\text { Applicable county } \\
\text { regulations. }\end{array}$ & $\begin{array}{l}\text { Driliing penmit. Water Re- } \\
\text { sources Division sole authority. } \\
\text { Land use permit by County } \\
\text { Planning Dept. }\end{array}$ & 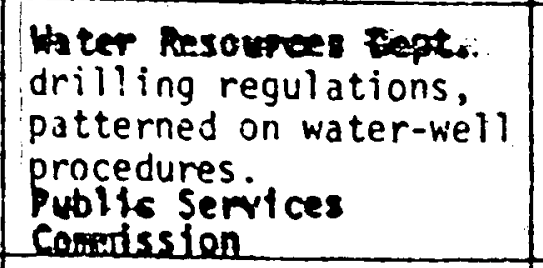 & $\begin{array}{l}\text { 1974 bill provides } \\
\text { for new laws to be } \\
\text { promulgated in } 1975 \\
\text { Targets are unclear } \\
\text { at present. }\end{array}$ \\
\hline Idaho & $\begin{array}{l}\text { Drilling permit. Water Resources } \\
\text { Dept. is sole authorit:. } \\
\text { County may require seecial use } \\
\text { permit in designated areas. }\end{array}$ & $\begin{array}{l}\text { Water Resol rces dept. } \\
\text { drilling rijations, } \\
\text { patteried oil \& gas } \\
\text { procedures } \\
\text { Applicat e c sunty regu- } \\
\text { lations. }\end{array}$ & $\begin{array}{l}\text { Development remit. Water Re- } \\
\text { sources Dipt. issues approval } \\
\text { after review by Heal th \& Welfare } \\
\text { Dept. } \\
\text { Public Utilities approve siting } \\
\text { of production plants. }\end{array}$ & $\begin{array}{l}\text { Water Resources Dept. } \\
\text { regulations. } \\
\text { Public Utilities. } \\
\text { Applicable county regu- } \\
\text { lations. }\end{array}$ & $\begin{array}{l}\text { Expansion of } \\
\text { county requirements } \\
\text { underway. }\end{array}$ \\
\hline Utah & $\begin{array}{l}\text { Drilling permit. Water } R: \text { ghts } \\
\text { Division is sole authority. } \\
\text { County may require land use } \\
\text { permit. }\end{array}$ & $\begin{array}{l}\text { Drillino rajlations } \\
\text { patterred after oil } \\
\text { gas orcedires. } \\
\text { Applicabie :ounty regu- } \\
\text { lations. }\end{array}$ & $\begin{array}{l}\text { Drilling permit. Water Rights } \\
\text { Division is sole authority. } \\
\text { County may require land use } \\
\text { permits. }\end{array}$ & $\begin{array}{l}\text { Orilling regulations.. } \\
\text { Applicable county regu- } \\
\text { lations. }\end{array}$ & $\begin{array}{l}\text { New regulations now } \\
\text { in process follow- } \\
\text { ing recent geo- } \\
\text { thermal legislation. }\end{array}$ \\
\hline
\end{tabular}

${ }^{2} E I R$ is required by State Lands Commission for state lard. However, except for Geysers area, all land of geothermal interest in California is private or Federal. NOTE: Applicable county regulations vary substantially. in rural oreas, county regulations may be very limited.
In urban areas, special rules may be in force. 
to those of California, which resemble $0 i 1$ and gas regulations. In Nevada, no state drilling permits are required. In Arizona, drilling permits are issued by the $0 i 1$ and Gas Comission and closely resemble those of California.

\section{B1.2 Development and Production}

In California, an EIR must be prepared by the county (private land) or the responsible state agency (state land) as a prerequisite to development drilling and power production. Approval of the project is subject to concurrence of several interested local and state agencies which participate in the EIR review. Approval is also subject to compliance with the various applicable local and state regulations. The requirements for developmental drilling are essentially identical to those for exploratory drilling. Construction of production facilities may begin after the county issues a land use permit, and the Energy Commission approves the site. In developmental drilling and production, the local air pollution control district and the regional water control district exercises a significant role in EIR review and project approval.

In Nevada, Utah, Idaho and Arizona an EIR is not required for development and production on state or private land. A land use permit may be required by the county and developmental drilling permits are required identically to exploratory drilling. These permits are often issued by a single agency, Table B-1. In each state, there is a designated authority responsible for approval of geothermal production sites, and an agency that regulates the utilization and sale of electrical power.

\section{B2 Federal Lands}

Requirements for development of geothermal resources on Federal lands are distinct in that the concept of full development is used from the outset. Issuing a Federal lease for geothermal development is contingent on the suitability and approval of total development including an eventual power plant. This initial requirement is the most significant impediment to developers of geothermal resources on 
Federal lands. Conversely, the greatest administrative deterrents facing developers on state or private lands may often occur downstream of exploration activities, when more stringent approval procedures are applied. Administrative problems are increased if a private/state land development spreads into adjacent Federal land. Currently, geothermal activities on Federal lands are also subject to state and local requirements. However, as geothermal activity increases, it is likely that redundant requirements will be reduced by coordination of state and Federal agencies.

Figure $B-2$ illustrates the administrative requirements for development of geothermal resources on Federal lands. The procedure is discussed below.

\section{B2.1 Exploration}

A developer must acquire Federal land by lease before substantial geothermal exploration may be conducted; Federal prospecting rights allow only superficial surface exploration. The Federal lease pertains to the entire cycle of geothermal development culminating in utilization of the geothermal resource: Accordingly, the lease applicant is required to submit a plan of operation for the proposed activities, and the BLM must prepare an environmental analysis report (EAR) for the proposed activities. The USGS and the Fish and Wildlife Department participate in the preparation of the EAR, as well as numerous state and local agencies. If the Director of the BLM determines the EAR to be adequate, a lease is issued which includes USGS stipulations designed to protect the environment. When the EAR is found to be inadequate, an environmental impact statement (EIS) must be prepared by the state BLM office with the participation of pertinent local and state agencies. Based on the EIS, the BLM will determine if a lease should be issued for the proposed geothermal project.

Two types of Federal 1 and leases are issued: noncompetitive leases for lands outside Known Geothermal Resources Areas (KGRA), and competitive leases for 1 ands within a KGRA. KGRA's are areas designated by the USGS aS prospects that have potential for commercial develop- 

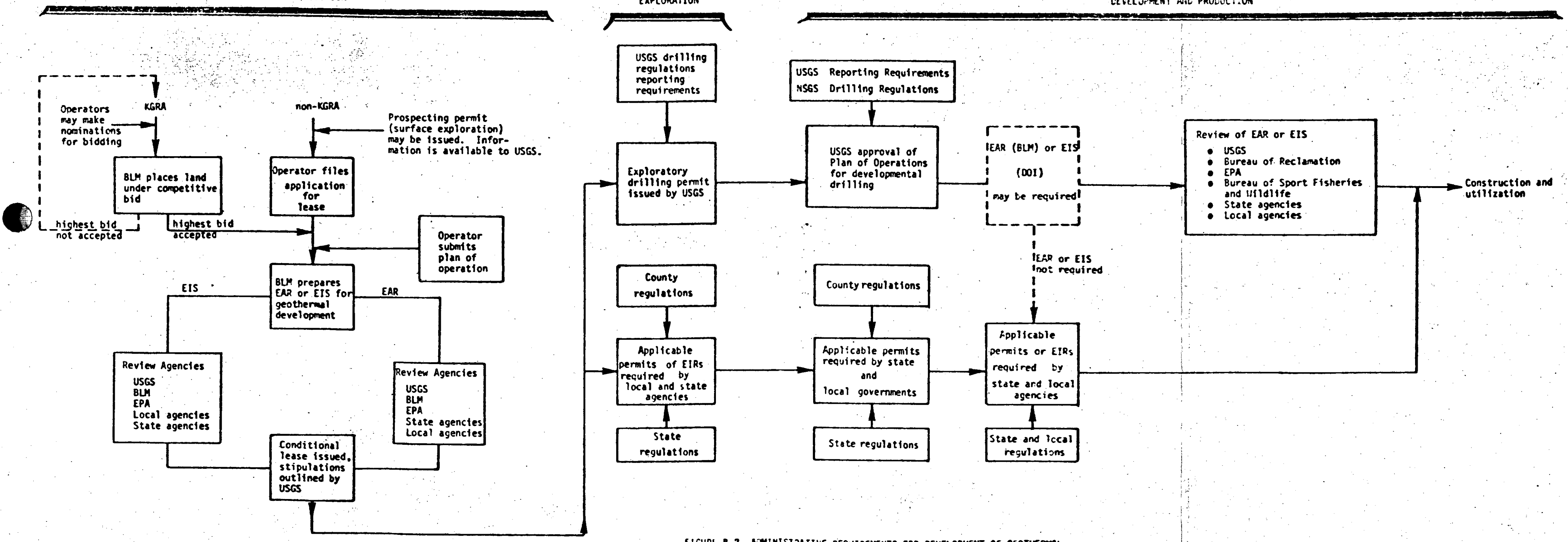

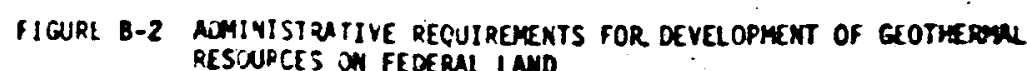


ment or as 1 and for which competitive interest for geothermal development has been displayed. In submitting an application for a non-competitive. lease, the applicant must provide a proposed plan of operation that provides a basis for the EAR preparation by the BLM. In competitive KGRA land, leasing the BLM must have prepared an EAR prior to the lease sale. Accordingly, a plan of operation is required only from the highest qualified bidder when a decision for a lease award is made.

There is a limit on the Federal acreage that can be leased. This limitation in effect allows only two prospects to be simultaneously developed in each state by a single developer. A maximum of 20,480 Federal acres can be leased by a single developer in each state.

A Federal 1 and lease is issued conditionally based on numerous stipulations which the USGS may impose to insure the protection of the environment and compliance with state and local regulations. An exploratory drilling permit is issued concurrently with the lease by the USGS. In addition to this permit, each state will require a drilling permit from the appropriate state geothermal agency. Where conflicting state, county and Federal regulations have not been resolved in the EAR and lease award processes, the coordination and resolution of theseoverlapping demands pose a significant deterrent to development. However, such conflicts should be addressed during multiple agency participation in the preparation of the EAR, and in the conditional stipulations imposed under the lease award.

\section{B2.2 Development and Production}

Development drilling may begin after USGS approval of a plan of operations for the area. The plan includes proposed well locations, with equipment, sites, roads and water sources noted; drilling and casing procedures and structural and hydrologic information. The operator is required to maintain records of operations and report monthly. Deviation from the initial plan such as a change in well location (or perhaps a side-tracked hole) requires approval. 
In accordance with the stipulations included in the lease, the leasee must respect Federal and state standards for control of air, land, water and noise pollution as well as all standards pertaining to public health and safety.

The administrative requirements governing the construction of a geothermal electrical power plant are anclear at this time. Some BLM officials have indicated that an EAR or EIS will probably be required by the Department of Interior. In addition, the states will also require certain permits and in the case of California, the state Energy Commission must have an EDS (Environmental Data Statement) or an EIR. Preparation of an EIS will require approximately 1.5 years.

\section{B3 Assessment by Developers}

For additional perspective, the viewpoints of four geothemal developers on administrative hurdles were obtained. Table B-2 is a brief summary of these. The developers are generally in agreement. Development in California is more difficult because of the number of adverse interest groups and the complex approval procedures. The remaining states generally possess reasonable policies and regulations. The most serious administrative problem concerns time delays.

The varying opinions in Table B-2 of the major deterrent facing commercial development at present is of particular interest.

Each of the four developers sees a different most important problem. While all of these developers voiced strong criticism of the administrative policies affecting geothermal development, each indicated an expanding commitment to commercial development of geothermal resources as a current company policy. 
TABLE B-2

ADMINISTRATIVE REQUIREMENT ASSESSMENT BY GEOTHERMAL RESOURCE DEVELOPERS

\begin{tabular}{|c|c|c|c|}
\hline DEVELOPER & $\begin{array}{l}\text { RANKING OF DESIRABILITY } \\
\text { FOR DEVELOP BY STATES } \\
\text { (LEAST DESIRABLE FIRST) }\end{array}$ & $\begin{array}{l}\text { MAJOR DETERRANT TO } \\
\text { COMMERCIAL EXPLOITATION }\end{array}$ & $\begin{array}{l}\text { VIEWPOINTS ON } \\
\text { FEDERAL LEASING }\end{array}$ \\
\hline $\begin{array}{l}\text { Gulf } 0 i 1 \\
\text { Company }\end{array}$ & $\begin{array}{l}\text { California } \\
\text { Oregon } \\
\text { Idaho } \\
\text { Idaho is pro-geothermal, and } \\
\text { Oregon has adopted favorable } \\
\text { attitude. California is } \\
\text { difficult due to many adverse } \\
\text { interest groups. }\end{array}$ & $\begin{array}{l}\text { Delays caused by procedural } \\
\text { redtape. Idleness generates } \\
\text { non-capital intensive activity. }\end{array}$ & $\begin{array}{l}\text { Not sidestepping Federal } \\
\text { leases but have had no } \\
\text { experience with Federal } \\
\text { land to date. Expect that } \\
\text { new Federal lease law } \\
\text { will have significant } \\
\text { impact on policies }\end{array}$ \\
\hline $\begin{array}{l}\text { Geothermal } \\
\text { Kinetics, } \\
\text { INC. }\end{array}$ & $\begin{array}{l}\text { Oregon } \\
\text { California } \\
\text { Montanna } \\
\text { Idaho } \\
\text { Utah } \\
\text { Arizona } \\
\text { Nevada }\end{array}$ & $\begin{array}{l}\text { Federal lease and regulatory } \\
\text { policies. Abundant delays and } \\
\text { unreasonable policies - for } \\
\text { example, the KGRA, a misnomer } \\
\text { that discourages development } \\
\text { and the high prices for leases. }\end{array}$ & $\begin{array}{l}\text { Geothermal developers exercise } \\
\text { general policy of avoiding } \\
\text { Federal land. }\end{array}$ \\
\hline $\begin{array}{l}\text { Chevron } 0 i l \\
\text { Company }\end{array}$ & $\begin{array}{l}\text { Oregon } \\
\text { California } \\
\text { Idaho } \\
\text { Nevada }\end{array}$ & $\begin{array}{l}\text { Acreage limitation for Federal } \\
\text { land. Prevents large operators } \\
\text { from full commitment. }\end{array}$ & $\begin{array}{l}\text { Approval and regulatory pro- } \\
\text { cedures offer no overwhelm- } \\
\text { ing problems. Most adminis- } \\
\text { trative agencies are in favor } \\
\text { of geothermal, and most } \\
\text { requirements are reasonable. }\end{array}$ \\
\hline $\begin{array}{l}\text { Union } 0 i 1 \\
\text { Company }\end{array}$ & $\begin{array}{l}\text { California } \\
\text { Oregon } \\
\text { Utah } \\
\text { Nevada }\end{array}$ & $\begin{array}{l}\text { Cut of oil depletion allowance. } \\
\text { Diminishes capital available for } \\
\text { geothermal. This is a major } \\
\text { recent event in continuing } \\
\text { examples of "people problems" } \\
\text { which deter development. }\end{array}$ & $\begin{array}{l}\text { Federal policies viewed very. } \\
\text { adversely. Slow on leasing, } \\
\text { excessive minimum bid levels } \\
\text { are set, excessive paperwork } \\
\text { required unreasonable cri- } \\
\text { teria for KGRA designation, } \\
\text { uncertainties in program. }\end{array}$ \\
\hline
\end{tabular}




\section{APPENDIX C \\ ENVIRONMENTAL AND SOCIO-ECONOMIC EFFECTS}

This appendix describes more details of the environmental and socioeconomic effects associated with geothermal development. Descriptions of the baseline environments and socio-economic conditions at the thirteen prospects are incorporated into the prospect narratives of Appendix $D$.

\section{Cl Background}

Initially, it is useful to compare the expected effects of geothermal power projects with those of fossil-fuel or nuclear projects supplying equivalent power. The following points are important:

- Nuclear and fossil-fueled power plants for large power markets will probably be about 1000 MWe in capacity, according to present economies of scale, while only the very largest geothermal projects will reach this size. Accordingly, the environmental effects of geothermal power development will be smaller in scale at a particuiar site than those associated with other power sources.

- All power plants require cooling, which is most inexpensively obtained by evaporating water, or by exchanging heat with a large volume of cool water, perhaps provided by ocean or river water. Geothermal fluids of high quality (either hot enough to flash into steam, or of low salinity) are a source of cooling water as well as power, and so have a large advantage over other power sources in the arid inland regions of the western United States. (Surface-mining of coal and subsequent land reclamation also require large amounts of water, representing a demand on the environment chargeable to power production from coal.)

- A geothermal plant using thermal water for evaporative cooling will probably emit some hydrogen sulfide to the atmosphere, along with a greater quantity of carbon dioxide. 
Improved control measures are being developed; however, in any case geothermal power will produce less emission per kilowatt hour than power produced from any fossil fuel except natural gas, or coal or oil of very low sulfur content. Geothermal plants, of course, do not emit smoke.

A probable ground rule for geothermal development in the United States will require that no geothermal fluids be discharged at or near the earth's surface. Almost all geothermal fluids have a TDS content > $1000 \mathrm{ppm}$, and surface or near-surface discharge would conflict with strong interests and strong laws protecting the quality of surface water and groundwater supplies. Most probably, then, geothermal fluids not evaporated in cooling towers will be reinjected into the deep subsurface by deep wells.

Reinjection may also be necessary to control ground subsidence over a geothermal reservoir. In relatively unconsolidated and incompetent rocks, such as the deltaic sediments of the Imperial Valley, it may be necessary to reinject as much fluid as is removed. In more competent rocks, not so dependent upon the pressure of pore water for support, it may be feasible to use part of the extracted fluids for evaporative cooling (not more than about $20 \%$ would be required for cooling at any of the prospects considered here) and to reinject the remainder as subsidence control.

The amount of tolerable subsidence may vary widely, from essentially none in an urban area or an agricultural region dependent on irrigation by gravity flow, to several feet in an uninhabited area if the drainage pattern is not disrupted. Further, reinjection can be a benefit as well as a requirement, as a means of maintaining reservoir pressure to maximize reservoir life.

A well-controlled geothermal development, then, can produce power with essentially no environmental effects other than those resulting from some human activity and the physical presence of wells, gathering-lines, power plant, cooling towers, transmission lines, roads, and probably an active drilling-rig engaged in continuing reservoir development. 


\section{C2 Environmental Effects}

\section{C2.1 Plant Life}

Some removal of plant life is an unavoidable consequence of geothermal development. Generally, this will involve one to three acres for the actual facility, while surface roads, transmission lines, well platforms, pipes and waste ponds necessitate additional removal.

Adverse effects resulting from vegetation removal in any area include:

- Increased erosion potential

- Reduction of wildlife habitat area

- Reduction of primary productivity

- Loss of natural landscape with concomitant reductions in aes thetics

The extent of these effects with respect to the total area involved is generally small, so vegetation removal is not usually considered to be of major significance. Re-seeding with native plants and landscaping are the usual measures of mitigation.

\section{C2.2 Wildlife}

Loss of habitat through surface disturbance is probably the most serious effect on wildlife resulting from development. This loss reduces the living area suitable for animals and removal of vegetation decreases the food sources upon which wildlife depend. Most animals are able to flee or avoid the area and are thereby not directly affected by the development, and many animals return to the site once construction has been completed. However, the presence of man or man-made objects is often enough to deter some animals from utilizing the area even if substantial. portions of the natural habitat are left intact.

Another potential effect of development on wildlife involves the accidental pollution of surface waters or surface water removal through diversion or utilization. This is particularly pertinent to aquatic life which depend on water availability for survival. 
Wildlife of particular concern are those species of plants and animals which are designated as rare or endangered. Preservation of these species is of prime importance to most wildlife conservationists and any serious threat to the survival of such species must be avoided in planning any project.

\section{C2.3 Air Pollution}

Increases in air pollution will inevitably occur as a result of geothermal development although these increases promise to be minor. The increased utilization of gasoline and/or diesel-powered vehicles and equipment in transporting of materials, exploring for the resource, and plant, road, and power line construction, operation and maintenance, will cause some deterioration in air quality. Increase in particulate matter generated by wind erosion following the removal of the vegetative cover is another potential source of air pollution. Still another potential source is the accidental escape of gases from the thermal fluids.

\section{C2.4 Water Pollution}

The uses of water in the drilling, construction and renewal phases of geothermal development probably offer the greatest causes for enviromental concern at most of the prospects considered here. Because many of the prospects are located in the vicinity of farmlands or other agricultural areas, and because abundant surface water is generally lacking, accidental pollution of surface or groundwaters or the utilization of waters for development of geothermal facilities would directly affect existing land uses. The associated effects could be substantial.

\section{C2.5. Noise}

Noise levels will also inevitably increase at each site as a consequence of geothermal development. Noise will result from the drilling of wells during the exploratory phase, from venting of wells during the testing phase and from construction of buildings, roads, transmission lines and other facilities during the construction phase. Increase in the vehicular traffic necessary for development will also increase the ambient noise. 
In general, the prospects of interest here are isolated and the relative noise increase is likely to be insignificant.

\section{C2.6 Topography}

The topography at each prospect will be affected to a degree. Construction of buildings, transmission lines, access roads, piping and waste or cooling ponds are a few of the more substantial sources of topographic change. While these changes cannot be avoided, mitigation methods include selecting an optimum location, constructing buildings to blend in with the surrounding environment and landscaping to minimize the visual impact.

\section{C3 Socio-economic Effects}

\section{C3.1 Employment}

The effects of geothermal development on employment and the local economy will be a function of the size of the development, the population in the vicinity, and the existing employment situation. Employment will be available for local or transient residents during all phases of development with peaking occurring during the main construction phase.

Exploration, using two drilling rigs, might require 40 people directly involved in the operation, with 10 to 20 additional service people needed. intermittently. If development procedes in an orderly fashion, the field development construction phase might require two to three rigs, employing 40 to 60 people, with an additional 30 to 100 people involved in actual construction. During production, five people might be needed to produce the field and five more might be required for each 110 MWe power plant. A single rig, with 20 people, might also be used during production.

In many of the prospects of interest here, the local population is small and the economy could undergo a "boom and bust" cycle. In these areas, local employment skills generally revolve around agriculture and the more industrial skills demanded by development would attract non-local residents. The resulting increase in transient work force could magnify the "boom and bust" characteristic. 


\section{C3.2 Population Trends}

Geothermal development will generally increase the local population with the greatest increase occurring during the construction phase. However, most of these workers are expected to be transient and permanent residents are expected only after production is established. The permanent population increase might range from 40 to several hundred persons and the effects of this increase on the services available in many of the prospect areas will be significant.

\section{C3.3 Aesthetics}

A reduction in the aesthetic values of each site is another unavoidable effect of geothermal development. Sources of potential visual intrusion include vegetation removal, physical appearance of installations, physical appearance of escaping steam columns and increased air and water pollution. The impact of these is a matter of personal preference and is very subjective. 
R 0 - $? 5-27$

\section{APPENDIX D \\ SPECIFIC PROSPECT DESCRIPTIONS}

This appendix contains generalized descriptions of each of the thirteen geothermal prospects that have been examined in this study. The prospects are arranged in alphabetical order for ease of reference.

These descriptions include the geologic setting, thermal spring data and generalized exploratory results involving geologic/geophysical investigations and exploratory wells. Also included are information on economic conditions, public attitudes, land ownership and uses, the natural environment, and other topics that would be of interest in determining the development potential of each prospect.

The prospect descriptions note the environmental and socio-economic areas where geothermal development could have a significant effect. Where effects are likely to be minor, no comment is made.

Each prospect description includes a map showing pertinent topographic, administrative, geological, and cultural features. These maps utilize standard United States Geological Survey topographic maps on a 1:250,000 scale as the base. For brevity, a single legend sheet has been prepared, Figure $D-1$, rather than including a legend on each individual map; standard USGS map symbolism is not included in this legend.

\section{Beowawe, Nevada}

The Beowawe area is in north-central Nevada, a few miles south of Interstate Highway 80 and approximately 20 miles east of-Battle Mountain. The area lies in Eureka and Lander Counties. A total of 33,225 acres have been classified as a KGRA. The area is mapped in Figure $D-2$. This prospect ranks number two in development potential.

The Beowawe prospect is in the Basin and Range province at the boundary between a plateau of Miocene (?) volcanics to the south and the downfaulted Whirlwind Valley to the north. Geysers, fumaroles and boiling springs have deposited an enormous sinter terrace approximately 300 feet 


\section{LEGEND}

KGRA BOUNDARY

$\delta$ THERMAL SPRING, FUMAROLE, GEYSER

- GEOTHERMAL WELL, DRILLING

申 GEOTHERMAL WELL, IDLE

\& GeOTHERMAL WeLL, ABANDONED

GeOlogic faulting

FIGURE D-1

$a b$ 
high. At the top, the terrace is approximately 100 feet wide and 2800 feet long (Ref. D-1). Hydrothermal activity occurs along faults at the top and at the foot of the terrace. Activity on the top is decreasing while activity at the foot is increasing. Cross-faulting has occurred recently and controls the lateral extent of the hydrothermal activity.

Beowawe has been the scene of much exploratory drilling (Ref. D-2). In 1959, Magma Power Company drilled two wells. The first missed a soughtafter fault, finding a temperature of $316^{\circ} \mathrm{F}$ at 1918 feet. The second apparently encountered the fault, finding a temperature of $414^{\circ} \mathrm{F}$ at 715 feet. In 1961, Vulcan Thermal Power Company drilled four wells to depths ranging from 655 to 767 feet, in line along the top of the terrace. These wells were drilled with cable tools; profiles of bottom-hole temperatures recorded during drilling skirted the curve of boiling-point versus hydrostatic pressure at depth, and levelled off at $405-410^{\circ} \mathrm{F}$ below 650 feet. After completion of the wells, involving some discharge of steam, shut-in temperatures of $380-390^{\circ} \mathrm{F}$ were measured. The Vulcan wells were flow-tested soon after completion. Three flowed about $1.5 \mathrm{million} \mathrm{lb} / \mathrm{hr}$ (roughly equivalent to $3000 \mathrm{GPM}$ ), at wellhead temperatures and pressures of $330-340^{\circ} \mathrm{F}$ and 90-115 psig, flashing 2-3\% steam. The fourth showed much lower flow, temperature, and pressure. In later tests (but before 1962), well performance further decreased and a 1965 test of Vulcan No. 4 found a pressure at 46 psig and a bottom-hole temperature of $340^{\circ} \mathrm{F}$ at 767 feet. In 1963-64, Vuican drilled two additional shallow but unsuccessful holes. The caps of several of these wells were later blown off by vandals, and one blew continuously for some time. Two others started blowing spontaneousiy in 1972, after a very dry winter while, simultaneously, the geysers and some of the hot springs stopped flowing. Sierra Pacific Power Company aiso drilled four unsuccessful wells in 1963-64 in a north-south line crossing the line of Vulcan wells. The deepest and hottest was the third with a bottom-hole temperature of $378^{\circ} \mathrm{F}$ at 2052 feet, and a very small flow of water and steam. In 1974, Chevron 011 Company and American Thermal Resources, Inc., drilled a well, Ginn No. 1-13, to a total depth of 9563 feet, in Sec. 13, T31N, R47E at a reported cost of about $\$ 1$ million. This well is located about 1.5 miles to the west of the previous wells, and about $1 / 4$ mile northwest of a projected normal fault line, on the downthrown side. 
The general test history is one of temperature and pressure declining as fluid is extracted, with various indications that the flows from the Vulcan wells interacted with the natural flo'ws and the water table. The Chevron well was apparently sited in hopes of finding a more reliable fluid source at greater depth. Chevron subsequently acquired additional leases in the area, indicating continuing interest and, presumably, encouraging results from this well.

The most encouraging feature of the Beowawe drilling is the consistently high geochemical estimates of maximum reservoir temperature. Dissolved $\mathrm{SiO}_{2}$ both in hot-spring water and geothermal well water runs from 450 to over $500 \mathrm{ppm}$, corresponding to quartz saturation above $450^{\circ} \mathrm{F}$. Na-K-Ca temperature estimates run from 400 to $480^{\circ} \mathrm{F}$. The sal inity of Beowawe water is low, about 1200 ppm TDS.

The area is very sparsely populated. The nearest urban center, Battle Mountain, has a population of 1850 . The population level and distribution are such that geothermal development could cause a "boom and bust" cycle, particularly in the construction phases. Increasing the population by a few hundred persons could severely strain existing services, i.e., law enforcement, schools, water supply, sewage disposal. However, geothermal development could eventually significantly increase the tax base, thereby allowing expansion and improvement of these services.

Employment centers around mining, ranching, and agriculture; there is, at present, almost no unemployment in the area. Long established residents may have reservations about development in the form of apprehension concerning greater demands on services but, in general, development appears to be welcome. The effects of geothermal development on this rural culture may be significant.

No data is available on land ownership or zoning. Land use principally involves mining, grazing and irrigation agriculture. A recent lease sale in the KGRA brought a bid of $\$ 204 / a c r e$, very high for geothermal land. In total, 11,830 acres were leased.

A regional environmental analysis pertaining to geothermal leasing has been prepared by the BLM (Ref. D-3). 
The landscape is typically desert. The general impression of the area is of bold, stark beauty and isolation. Coloration is drab. The visual beauty has been substantially altered by cultural features, i.e., roads, power lines and mines. Additional cultural features introduced by development will be readily visible.

The Humboldt River is the largest surface water resource in the immediate area; shallow groundwater of good quality is also available. The thermal area is not inhabited and the ambient noise level is low. Air quality is undetermined. The principal pollutant is wind-borne dust while insignificant quantities of sulphur dioxide and hydrogen sulfide are released by the hot springs.

Major vegetation in the area includes greasewood, shadscale, rabbitbrush, big sage, winter fat, wild-rye, squirreltail, and cheat grass. Dominant wildlife includes wild horse, fox, weasel, bat, coyote, bobcat, rabbit, mule deer and prong-horn antelope. There are two rare/endangered species (Ref. D-4) in the general region, the Spotted Bat and a relict fish found in the Carico Lake Valley. Aquatic plantlife is found in the thermal springs. The spring water is heavily used by wildlife and livestock.

There are historical and archeological artifacts in the general region. The Immigrant Trail lies to the north and the Pony Express route lies to the south. Shoshone and Piute Indians have inhabited the area in the past. 


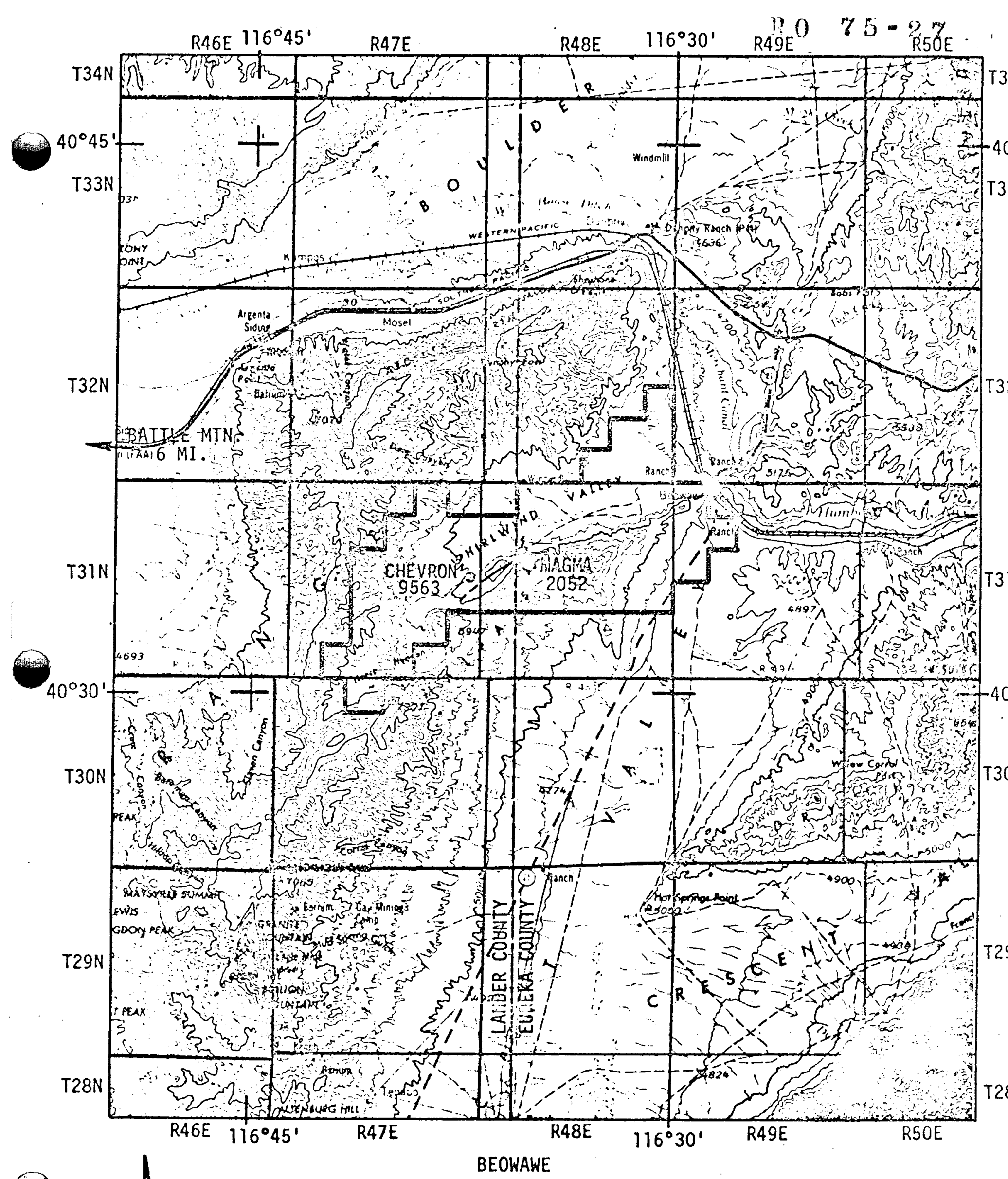


D2 Brady's Hot Springs, Nevada

Brady's Hot Springs is located in west-central Nevada, approximately 50 miles east of Reno and one mile from Interstate Highway 80 . The area is in Churchill County. Hot springs exist and 98,446 acres have been classified as a KGRA. The area is mapped on Figure D-3. This prospect ranks number five in development potential.

The thermal area lies in the Basin and Range province. In the immediate area, Tertiary sediments and volcanics and Quarternary alluvium and lacustrine deposits are present. Jurassic basement outcrops to the north and the younger sediment lap onto the basement.

Thermal activity lies along the Brady Thermal Fault, the dominant structural feature in the area. The fault trends northerly for approximately six miles; movement may have been strike-slip but cannot be ascertained as the scarp is covered by alluvium. There is some evidence of recent activity. The principal evidence for the existence of this fault is the hydrothermal activity; hydrothermal deposits mark its trace for approximately 2.5 miles. A low sinter terrace has been deposited by the thermal springs and geothermal activity has evidently been continuous for 10-11,000 years (Refs. D-1 and D-2).

Several shallow wells, drilled by Magma Power Company from 1959-1961, tapped hot water and steam from the fault zone at depths of a few hundred feet. Following this drilling, the fault trace was delineated for a year or so by a three-mile line of new steam vents, while most of the original springs went dry. These early wells showed good initial flows, but were repeatedly choked by calcite deposits. A well drilled in 1964 by Earth Energy, Inc., to 5062 feet in the same vicinity showed a roughly linear static temperature profile from $274^{\circ} \mathrm{F}$ at 800 feet to $414^{\circ} \mathrm{F}$ at 5062 feet TD. On test, this well produced 120 GPM of water and steam from a 230-foot zone through 4-1/2" slotted liner at 4900 feet. Recently, Phillips and Union $0 i 1$ Companies have each drilled a well deeper than 7000 feet, and Magma has drilled two wells to 3500 feet and 4500 feet near the old holes.

Chemical estimates of maximum reservoir temperature from analyses of hot spring water and shallow geothermal well water agree very well, giving 
quartz and $\mathrm{Na}-\mathrm{K}-\mathrm{Ca}$ temperature estimates in the range $370-390^{\circ} \mathrm{F}$. Total dissolved solids in all samples is about $2500 \mathrm{ppm}$. The higher temperatures actually observed at 5000 feet and the interactions between shallow wells and springs suggest that ground water, in communication with the local water table, affects the flow in the near-surface levels of the fault zone. Recent exploratory wells seem to be directed at deeper sources, probably in hopes of more stable as well as hotter wells.

The estimated population of Churchill County in 1975 is 11,600 . By 1990 , a population of 14,865 is anticipated. The nearest town, Fernley, has 900 residents.

The county is rural. Employment is as follows in order of importance: agriculture government recreation construction transportation manufacturing mining

The area at Brady's Hot Springs is suitable for rural resource conservation, wildlife habitation, open space and rangeland; it is poorly suited for most development activities. The county is very aware of and concerned with maintaining open areas in the natural state. Geothermal development is not seen to confilict with this conservation philosophy but could cause a "boom and bust" cycle. A relatively small population increase could strain the existing service sector (the town of Fernley may be particularly affected) although the eventual increase in tax base from geothermal power production would mitigate this. Local residents are in favor of geothermal development. County officials also encourage development but at a rate that can be planned and controlled. .

A general plan for land use in Churchill County exists (Ref. D-5). County land ownership is $90 \%$ Federal (BLM and Bureau of Reclamation), $9 \%$ private and $1 \%$ state and county. The area is classified as open space under the BLM multi-usage category. Most Federal land is used for grazing and most private land is used for agriculture. A total of 3200 acres were recentiy leased in the KGRA. 
BLM has prepared an environmental analysis of the thermal area (Ref. D-6) and the county general plan includes a partial environmental impact statement.

The area is flat and arid with hills rising approximately 2000 feet to the west. The elevation of the thermal area is approximately 4000 feet. Topographical features include alkali flats, dry washes and buttes. Culture includes roads, power lines and gravel pits. Brady's Hot Springs is not a site of scenic or aesthetic quality.

There are no permanent streams near the thermal area but shallow ground water is available. Air quality has not been measured but is very good; visibility in the area is excellent. Ambient noise has not been measured but a relatively high level might be expected, generated by nearby Interstate 80 .

Vegetation is typical desert scrub including greasewood, sage, salt grass and squirreltail. Wildlife includes coyote, bobcat, rabbit, porcupine, mule deer, and many birds. There are no aquatic plants or animals in the thermal area and no data exists on the presence of rare/ endangered species.

No systematic survey of archeological sites has been made although the history of the site includes numerous mining camps. 


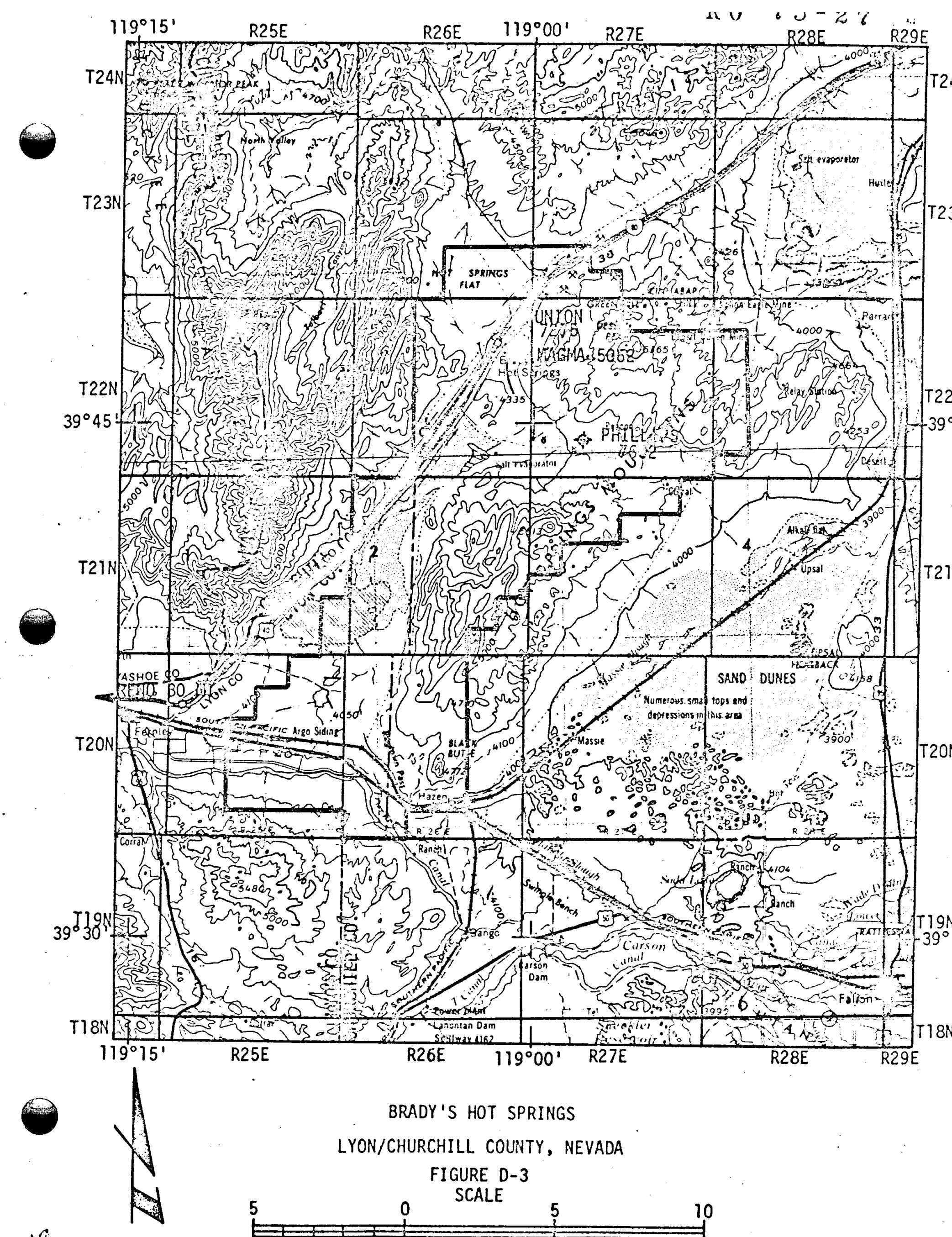




\section{D3 Brigham City, Utah}

The Brigham City area is located in north-central Utah approximately six miles northwest of Brigham City and 50 miles north of Salt Lake City. The area is in Box Elder County. While hot springs exist in the area, no KGRA has been defined. The area is mapped on Figure D-4. This prospect ranks number 12 in development potential.

This prospect has been the site of a deep geothermal test, drilled in Sec. 16, TION, R2W by Geothermal Kinetics, Incorporated and Utah Power and Light Company.

This well was drilled in the main fault zone of the Wasatch Front, a predominate structural feature that extends in a north-south direction through most of Northern Utah. The front represents the eastern limit to the Basin and Range province and is marked throughout its length by a chain of thermal springs. Nearby hot springs on this fault zone (Crystal Hot Springs and Stinking Hot Springs) have $\mathrm{Na}-\mathrm{K}-\mathrm{Ca}$ estimated temperatures of $370^{\circ} \mathrm{F}$, but less than $50 \mathrm{ppm} \mathrm{SiO}_{2}$, corresponding to quartz temperature estimates below $212^{\circ} \mathrm{F}$. Total dissolved solids amount to about $40,000 \mathrm{ppm}$ (Refs. D-7 and D-8).

The operator reports that well was drilled on the basis of an aerial infrared survey showing a vegetation-related anomaly, and resistivity surveys showing a marked anomaly in the same place. The well was not drilled on the center of the anomaly, but on the western edge, for reasons based on the surface geology of the area. The nearby sequence of sedimentary rocks exposed on Wellsville Mountain, east of the Wasatch Front begins with lower Cabrian, and this sequence was expected to be underlain by Pre-Cambrian basement at depth. Further, suitable sedimentary reservoir rocks were expected to be better sought in the down-faulted block west of the main fault zone. However, the well penetrated an unsuspected major thrust fault within the down-faulted block, and continued on, through the zone of normal faulting; to find Paleozoic rocks and a second major thrust fault at about 11,000 feet. 
A drill-stem test at about $8250^{\prime}$ produced water of $54,000 \mathrm{ppm}$ TDS, with $305 \mathrm{ppm} \mathrm{SiO}_{2}$, giving a quartz temperature estimate of about $405^{\circ} \mathrm{F}$. The $\mathrm{Na}-\mathrm{K}-\mathrm{Ca}$ temperature estimate is about $570^{\circ} \mathrm{F}$. Below this depth, within the zone of normal faulting, there is hydrothermal alteration of a shale sequence. The highest temperature recorded in the course of drilling and logging the well was $284^{\circ} \mathrm{F}$.

The initial flow in this well came from in and below the last normal fault encountered, at 10,350 feet. Flow soon ceased indicating that the well did not penetrate a good producing zone. The high chemical temperatures, the geophysical anomalies, and the structural information revealed by the well, however, are evidence of the possibility of a viable prospect being still in existence.

The prospect lies directly in the principal urban and transportation corridor of the state of Utah. The drill site is only a few hundred feet from Interstate Highway 15 . The general area is heavily populated for the Mountain States; the population of nearby Brigham City is 14,000. Population in the immediate vicinity of the prospect is sparse; there is one resident approximately one mile from the drill site.

The economy in the vicinity of the prospect is based upon agriculture while the Brigham City urban area supports trade, services, and industry. The county plans to maintain the prospect area as agricultural and encourages geothermal development at a controlled growth rate as a source of increased revenue and water resources. The public is excited by potential geothermal activities.

This prospect is located on private land zoned for agriculture. A use permit is required for exploration. The county does not require an EIS before development. Other land in the vicinity is included in an "open" zone category.

The landscape consists of a very wide, flat valley bordered on the East by mountains. The natural environment has been affected by grazing and by construction of the interstate highway. There is little of aesthetic value in the area. 
Surface water supplies are adequate for ordinary usage, but developing alternative water sources is encouraged. Air quality is unmeasured but good and the ambient noise level is also unmeasured, but could be somewhat high because of interstate highway traffic.

Vegetation is Great Basin scrub featuring sagebrush, cattail and tule marsh grass. There is a waterfowl refuge about 20 miles from the prospect. No data on aquatic life is available. Rare/endangered species in the general area include three fish (Humpback Chub, Colorado River Squawfish and Woundfin), Peregrine Falcon, Black-footed Ferret, and Utah Prairie Dog. None of these have been reported on the prospect.

No data on historic or archeological artifacts are available. 


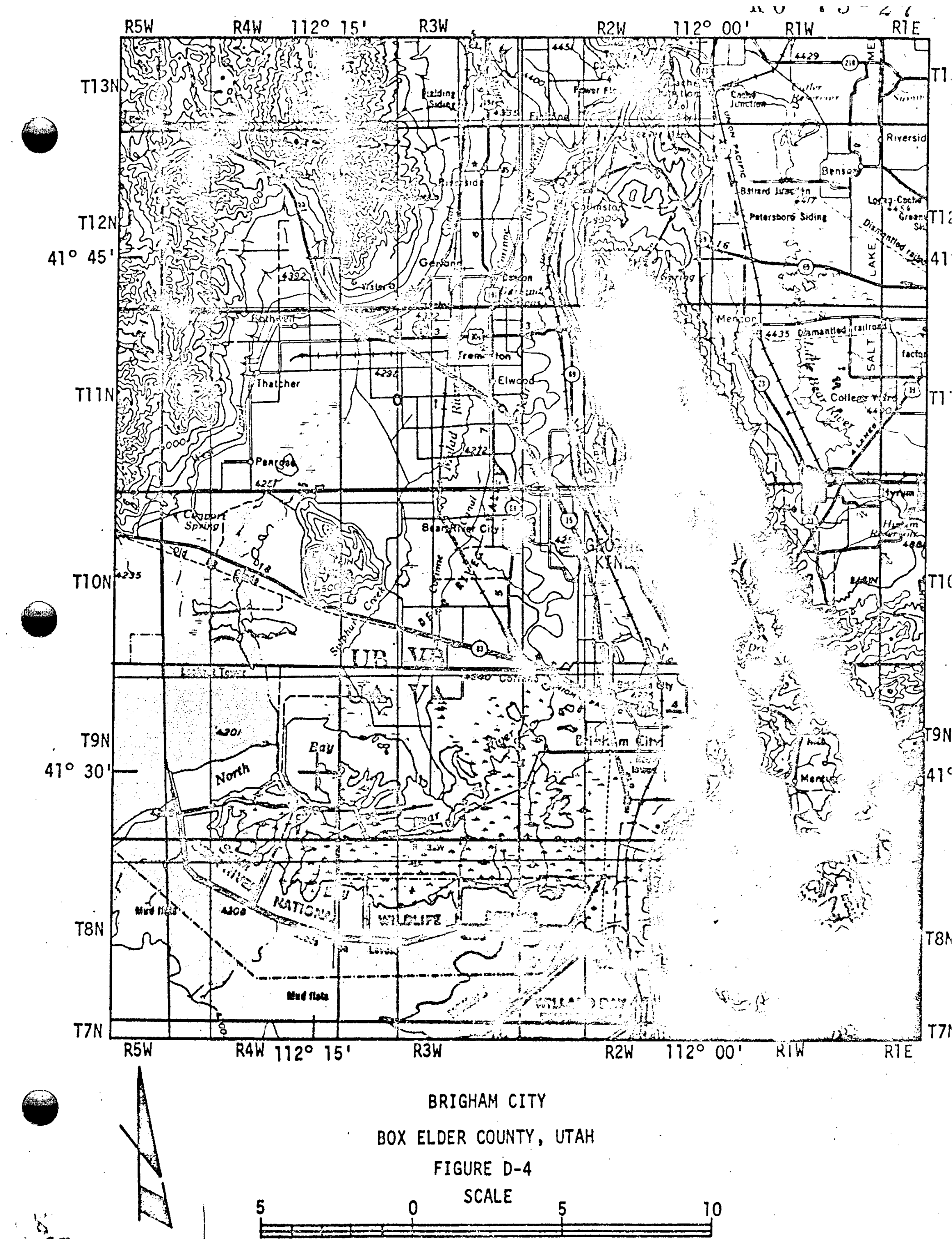




\section{D4 Chandler, Arizona}

The Chandler area is located in south-central Arizona, 25 miles southeast of the Phoenix metropolian area. The prospect is in Maricopa County. There are no thermal springs and no KGRA has been defined. The area is mapped on Figure $\mathrm{D}-5$. This prospect ranks number 13 in development potential.

The area is in the Basin and Range province, roughly 60 miles south of the edge of the Colorado Plateau. It is the site of two deep geothermal wells drilled by Geothermal Kinetics, Incorporated, in Sec. 1, T2S, RGE. The operator has reported that these wells were located on the basis of aerial infrared anomaly and a resistivity anomaly. Both wells penetrated slightly more than 5000 feet of alluvium, evaporite, and sedimentary section before entering volcanic rock. No. 1 bottomed in volcanics at 9200 feet, while No. 2 reached basement at 10,250 feet. The volcanic rocks generally have a high pore fraction, but the permeability is low. Flow can be attained from fractures, however. The operator estimates that while No. I was being drilled with aerated water in the neighborhood of 8800 feet, the open hole produced between 4000 and 6000 GPM of excess water. Neither well was a good producer when completed with slotted or perforated liner, and downhole pumps .

The best temperature profile available is from No. 2, obtained after two months of standing, showing a linear increase from $250^{\circ} \mathrm{F}$ at 7000 feet to $352^{\circ} \mathrm{F}$ at 10,450 feet. Well No. 1, after standing somewhat longer, showed $305^{\circ} \mathrm{F}$ in a drill-stem test at about 9000 feet, which falls on the same temperature-with-depth profile. Water pumped from perforations between 6100 and 9000 feet in No. 1 showed $62,000 \mathrm{ppm} \mathrm{TDS,} 60 \mathrm{ppm} \mathrm{SiO} 2$, and a. $\mathrm{Na}-\mathrm{K}-\mathrm{Ca}$ estimated temperature of $\sim 300^{\circ} \mathrm{F}$. This water may, be contaminated by salt-based drilling mud.

The estimated present population of Maricopa County is one million persons, most of whom reside in the Phoenix metropolitan area. A population of two and one half million is anticipated in the year 2000. (In 1900, the county population was 20,000 ).

Manufacturing followed by agriculture form the economic bases of the county. The general picture is that of urbanized areas surrounded by farmland. Urbanized area in the county is planned to increase from 160 
to 451 square miles by 1980 while agricultural area will decrease from 860 to 707 square miles. Currently, the Phoenix region receives its electric power from dams located on the Salt River. Geothermal power development would be an asset, but does not have a significant position in future planning. There is not much public interest in geothermal.

A general land use plan for the county exists (Ref. D-9), but no environmental reports are known. Land ownership in the county is as follows:

$\begin{array}{lr}\text { Bureau of Land Management } & 31 \% \\ \text { Forest Service } & 11 \% \\ \text { Department of Defense } & 14 \% \\ \text { Bureau of Indian Affiars } & 5 \% \\ \text { State } & 10 \% \\ \text { Regional Parks } & 2 \% \\ \text { Private } & 7 \%\end{array}$

There are five Indian Reservations in the county. The prospect site is on private land.

Land use in the county is as follows:

$\begin{array}{lr}\text { Urban } & 1.7 \% \\ \text { Agriculture } & 9.3 \% \\ \text { Open Space } & 26.3 \% \\ \text { Indian Reservation } & 4.5 \% \\ \text { Desert/mountains } & 58.0 \%\end{array}$

Land outside the urban areas are generally zoned for agriculture (Ref. D-10). The prospect site is used for grazing and farming.

The prospect is located on flat desert mixed with irrigated farmlands bordered by mountains on the west. Dry stream washes and arroyos are characteristic of the area. Williams Air Force Base adjoins the prospect. All natural landscape has been altered and there is little aesthetic appeal.

Two major river systems, Salt River and Verde River, flow in the region. Phoenix imposes great demands on the Salt and this river and its tributaries can become dry south of the city. Air quality is good with an ordinary visibility of 30-40 miles. The ambient noise level is relatively high; generated by airplane traffic at the Air Base, automobile traffic, and farm machinery. 
The general prospect site is planted in cotton and citrus. Nearly all natural vegetation has been altered; remaining plants include creosote, burrobush, and mesquite. Species characteristic of disturbed habitats such as sunflower and Russian thistle flourish.

Wildlife consists of reptiles, birds, and small burrowing rodents. Aquatic life is confined to irrigation canals, the most evident of which are algae, bivalves, and snails. No rare/endangered species inhabit the area.

Given the disturbance to the natural environment that has already occurred, the possibility of locating historical or archeological sites in the area appears remote. None are now known. 


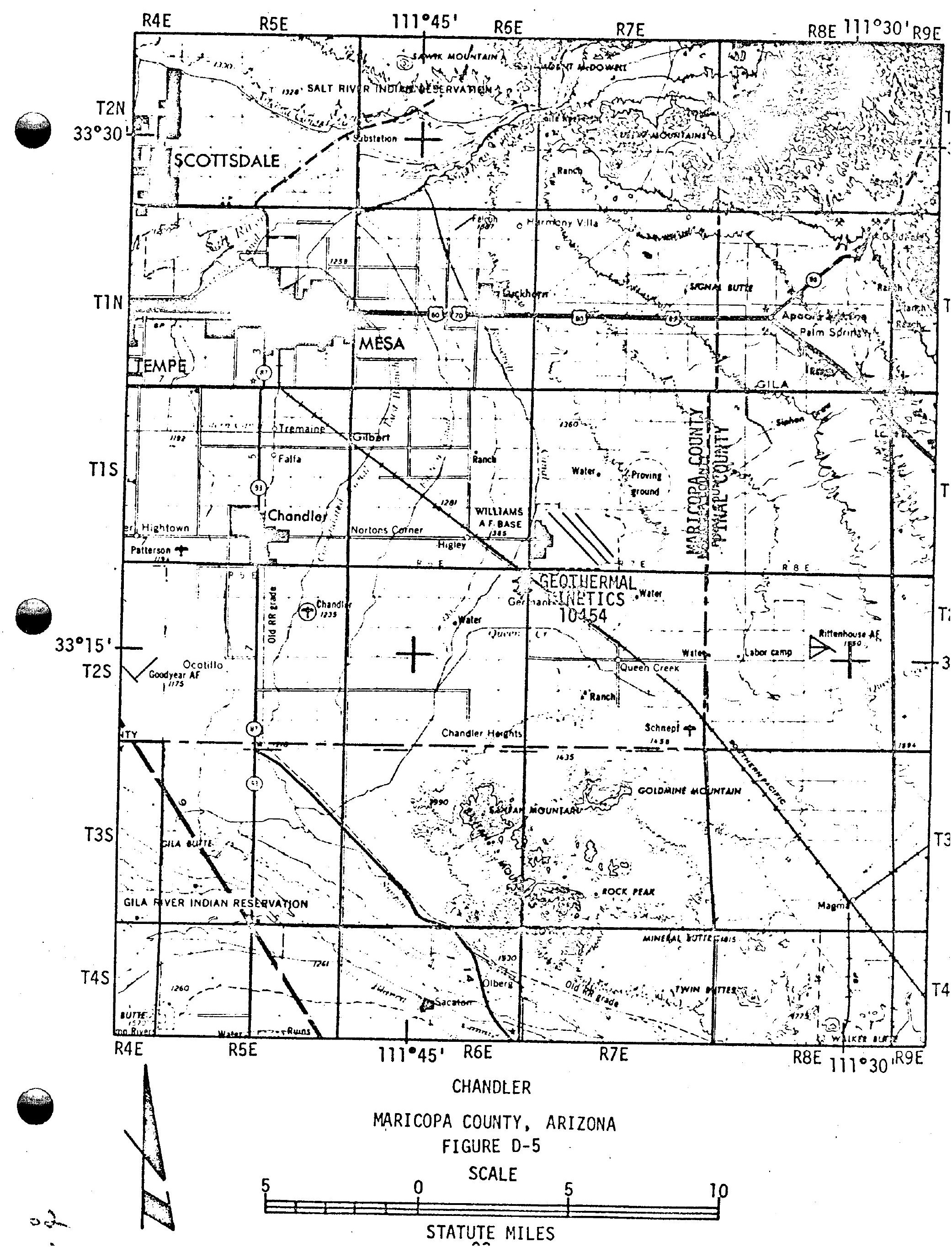


D5 Clear Lake, Californta

The Clear Lake area is located in west-central Californta, approximately 75 miles north of San Francisco and 15 miles north of the Geyers geothermal field. The area is in Lake county. There are hot springs and the area lies within the 374,910 acre Geysers KGRA. The area is mapped in Figure D-6. This prospect ranks number seven in development potential.

The specific area of interest involves the Clear Lake volcanic field, covering an area of approximately 85 square miles immediately south of Clear Lake. These volcanics are a series of flows, domes, tuffs, and pyroclastics, Pleistocene and Holocene in age, and of a variety of petrographic types. It is probable that these volcanics were extruded onto a rugged erosional surface so that the volcanic thickness may vary considerably within a locality. The volcanic field has also been subjected to Pleistocene and Holocene tectonic movement; arcuate fault patterns may indicate Cenezoic uplift or subsidence. Mt. Konocti, Mt. Hanna, and other mountains in the area are volcanic in origin and some of these may be vents or plugs.

Thermal springs are plentiful although data on these are sparse. Siegler Springs in the eastern part of the area flow in excess of 15 GPM at a maximum temperature of approximately $125^{\circ} \mathrm{F}$. The Sulphur Bank area to the northeast contains springs delivering minor flows at temperatures near $180^{\circ} \mathrm{F}$.

A deep well was drilled at Mt. Konocti by Getty 011 in 1972, bottoming at 8566 feet. "Interesting" temperatures were encountered but no permeability. The hole was subsequently sold to Pacific Energy Corporation who considered deepening, but later abandoned it. Four wells were drilled earlier (19611964) in the Sulphur Bank mine area on the east side of Clear Lake. One well went to approximately 5000 feet; another went to 1400 feet. The maximum temperature exceeded $350^{\circ} \mathrm{F}$. Well fluid was hot water with an approximate five percent steam flashover. The 1400 foot well produced over 50,000 pounds of steam and 1.5 million pounds of water per hour at a pressure of approximately 100 psig. The water contains problem amounts of boron and carbon dioxide.

A major negative gravity anomaly is centered in the southern portion of the volcanic field. (Reference $D-11$ ). The relative position of the anomaly to the volcanics suggests a genetic relationship, but the cause of 
the anomaly is not apparent al though several plausible causes can be postulated. The anomaly does not coincide with any known structural feature nor is there a magnetic counterpart to the anomaly.

One possible cause of this anomaly involves the volcanic field being calderic in origin and this is supported by the arcuate fracturing in the area. Still another possible cause involves the existence of a deep, high porosity geothermal reservoir; this most attractive alternative is supported by preliminary deep resistivity measurements that show a large low resistivity zone generally coincident with the gravity anomaly. The vertical extent of this low resistivity zone is approximately 15,000 feet.

Lake County now has approximately 20,000 permanent residents, with 35,000 being projected by 1985 . The two nearest population centers, Kelseyville to the west and Lakeport, 25 miles to the northwest, have 900 (2700 in Summer season) and 3000 residents, respectively.

The economy of Lake County is primarily tourist-oriented and agriculture is also a significant factor. Future planning involves expansion of recreational areas and facilities although there has been a recent decline in tourism. Residential homesites are numerous, particularly near Anderson Springs where land values have increased by as much as a factor of 16 . Plans for the area also involve zoning for housing sub-divisions and identification and conservation of forests, wilderness areas, and wildlife refuges. Geothermal planning is oriented toward large-scale development. Public opinion is split on geothermal development; a survey has been taken to determine true public feeling. Significant opposition may be expected from residential and environmental groups.

A general plan for Lake County exists (Reference $D-12)^{\circ}$. Three environmental reports on the general area are available (References D-13, D-14 and D-15).

Land ownership in the county is 44 percent Federal, 45 percent private, and 1 percent urban. Much of the county is not yet zoned; zoning near promising geothermal areas includes some residential.

The topography of Southern Lake County is mountainous with steep slopes, rocky outcrops, canyons and small valleys. Streams abound and two man-made 
and several natural lakes exist. This is an area of significant scenic beauty and the effects of gecthermal development on aesthetics could be significant.

Surface and ground waters are plentiful and of good quality. Air quality in the area is relatively high and the ambient noise level is very low, approximately $45 \mathrm{dbA}$.

Vegetation is primarily grassland, chapparral and mixed evergreen forests. Trees include sugar and ponderosa pines, Douglas firs, maples, and oaks. Dominant wildlife includes deer, bear, coyote, bobcat, skunk, squirrel, quail, snake, and lizard. Steelhead and other trout are found in Anderson and Bear Creeks. There are no rare/endangered species in the area (Reference $D-16$ ).

Many old Indian (Pomo, Wintyn, Miwok, and Wappo) settlements are known to have existed in the area. 
R $0 \quad 75-27$

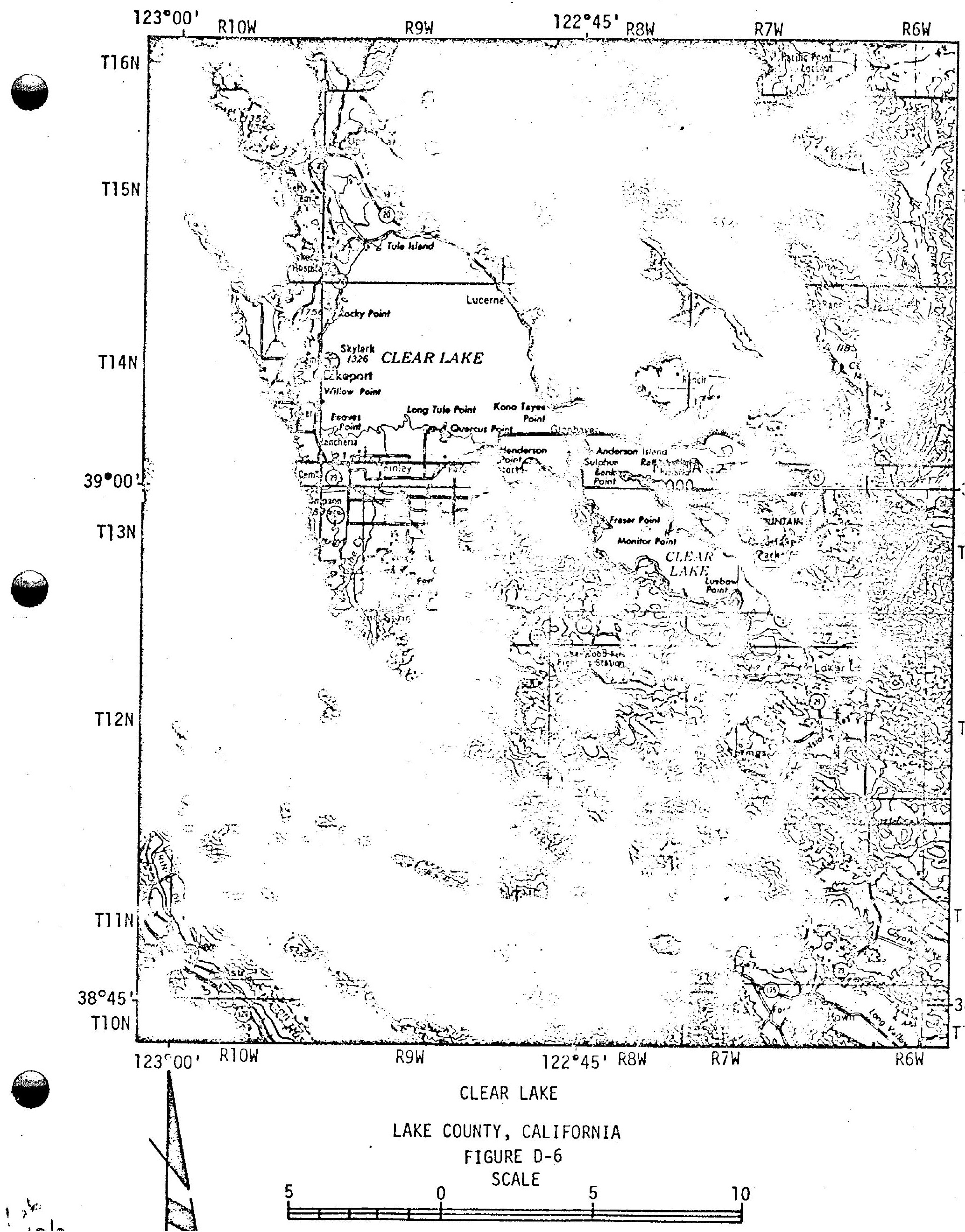


The Coso Hot Springs area is located in east-central California, approximately 300 miles north of Los Angeles and 35 miles north of China Lake. The area is in Inyo County. Hot springs and fumaroles exist and 51,760 acres have been classified as a KGRA. The area is mapped on Figure D-7. This prospect ranks number three in development potential.

The thermal area lies in the Mojave Desert west of the Sierra Nevada Range. Specifically, the thermal area is located in the southern part of the Coso Range, a region marked by young (Pleistocene and Holocene) volcanics; i.e., cinder cones, domes, and flows. Volcanism may be occurred as recently as 5000 years ago.

Much of the Coso Range is enclosed by an arcuate faulting system that forms a rough oval measuring approximately 25 miles east-west and 28 miles north-south. This arcuate structure is broken by a set of northeast and northwest trending, steeply dipping faults. The ring faulting and associated structural subsidence suggest a caldera in the early stages of collapse. (Reference D-17).

The geothermally interesting area occupies approximately 80 square miles, 65 of which 1 ie within the boundaries of the Naval Weapons Center, China Lake. Accordingly, the principal portion of the area is controlled by the U. S. Navy and the Navy has announced plans to integrate the geothermal energy with other energy sources to form a "Total Energy Community". These plans include a geothermal materials test facility and a 20 MWe power plant (Reference D-18). The military reservation is not open to the general public.

Coso Hot Springs is a series of fumaroles and hot springs that occurs along one of the northeast-trending faults. Hydrothermal alteration is . common in the area. Recent analyses of the spring water indicates a TDS content of 1-2000 ppm and a silicate content of 2-300 ppm. The spring water is highly acidic and lacking in chloride. Maximum temperatures exceed $200^{\circ} \mathrm{F}$.

More than 25 shallow wells were drilled in the Twenties and Thirties when a resort was operated. In 1967, the Navy drilled a shallow (375 feet) 
well by cable tool. The hole penetrated hematite-stained alluvium to 185 - feet where granitic basement (?) was encountered. The hole bottomed in this basement rock. A bottom-hole temperature of $288^{\circ} \mathrm{F}$ was measured. The water recovered from this well is neutral to alkaline and is rich in chloride, in contrast to the spring water. The well produced at rates to 40 GPM although the productive capacity has not been determined. However, a 240 pound swab was blown from the hole during testing, indicating a downhole pressure in excess of 20 psig (Reference D-19).

The Coso thermal area is now the scene of a geophysical investigation program being conducted by Dr. James Combs of the University of Texas at Dallas (Reference D-20). This investigation involves heat flow and microearthquake studies. No heat flow results have been made available to date. Microearthquake activity is of the swarm type indicating that tectonic forces are currentiy active in the area. P-wave and $S$-wave velocities have been determined and these infer a very low Poisson's ratio in the shallow subsurface. This low ratio implies that the shallow subsurface is not water-saturated and that a vapor-dominated reservoir exists.

The present population of Inyo County is 17,000. An increase to 26,000 is anticipated by 1990. The population of China Lake and surrounding communities, the nearest urban center, is 13,500 .

Tourism, recreation and government employ most of the labor force in the county. The military is the principal employer in the immediate area. Future growth is expected in recreation and tourism; agriculture has been declining because of a lack of irrigation water. County development must occur outside of the military reservation. The public is relatively uninformed about geothermal energy, but significant public opposition to development is not expected.

A general plan for land use exists (Reference 0-21). In Inyo County, approximately 92 percent of the land is Federally owned (primarily by the Bureau of Land Management) and the remaining 8 percent is privately owned (primarily by the Los Angeles Department of Water and Power). Principal land uses are recreation, military, and agriculture. County zoning does not apply within the military reservation. The Navy is reportedly encouraging commercial development of Coso Springs. No lease sales within the KGRA are scheduled. 
The landscape is typical desert with no outstanding aesthetic qualities. Water is in short supply with much of the indigeneous water being transported to Los Angeles. Owens Lake to the north is now dry. The Los Angeles Aquaduct passes a few miles from the prospect and is a potential source of cooling water. Ground water is another potential source; withdrawal for irrigation has not caused subsidence to date. Air quality is good, but has recently deteriorated because of flow from the Los Angeles Basin. Data on ambient noise is unavailable, but it is probably very low.

An environmental study of the area has been done by the Navy. Vegetation is of the desert scrub type. The fauna are typical of the desert including coyote, fox, rabbit, rat, squirrel, sparrow, lark, raven, and various species of lizards. Three rare/endangered species exist in the general region, the Owens Chub, Owen Pudfish, and the Mohave Ground Squirrel. There is no aquatic life in the prospect.

The area has been inhabited by the Piute Indians and many landmarks remain from the goldrush of the mid-1800s. 

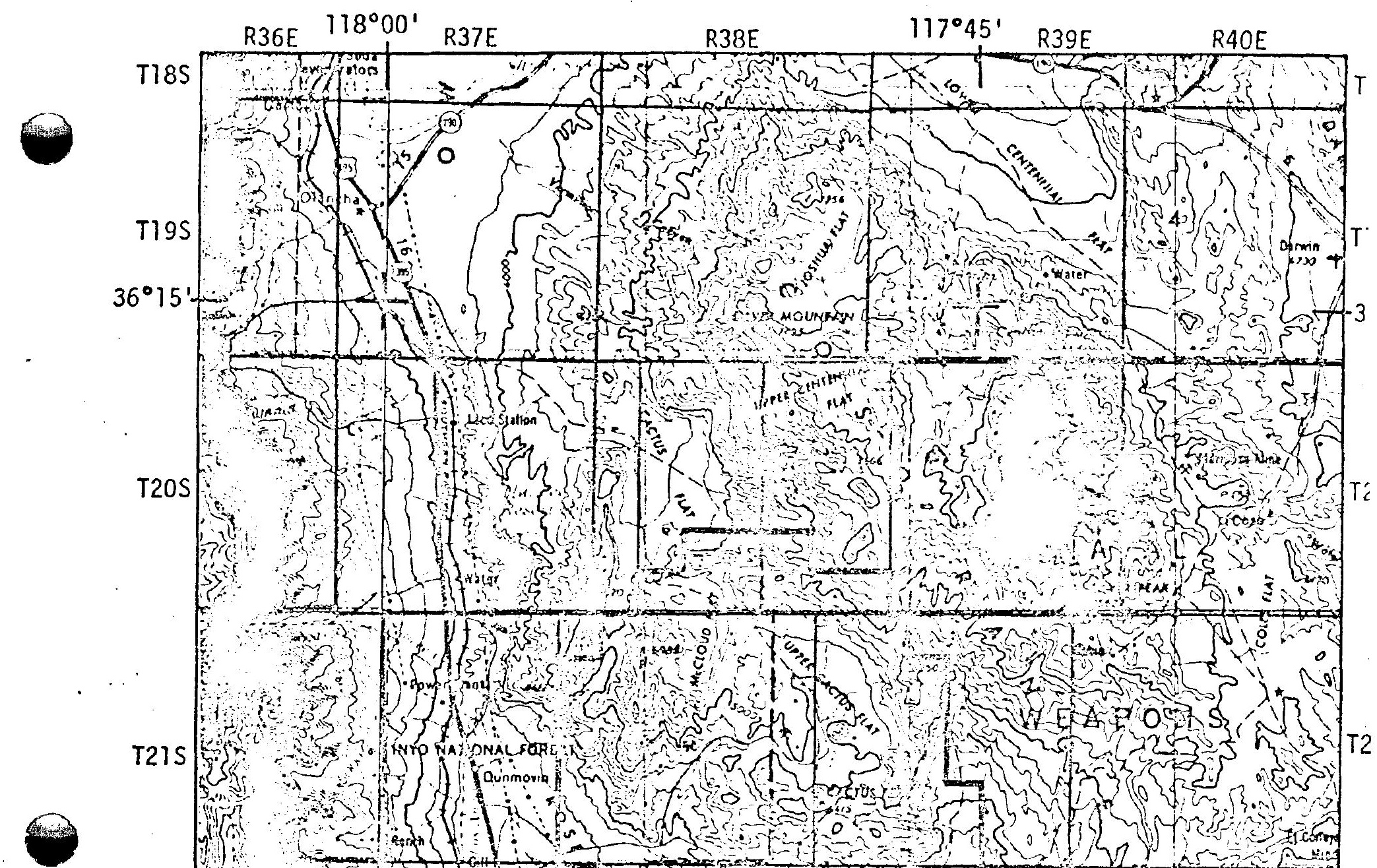

T21S

$36^{\circ} 00$

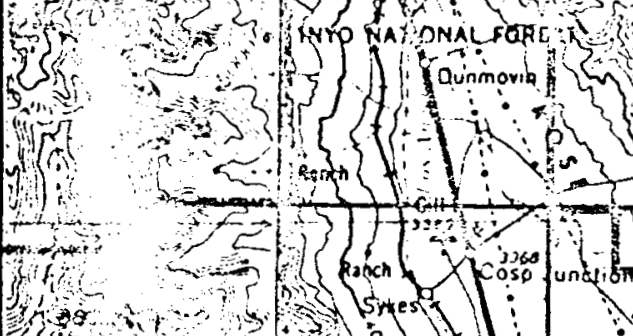

N 


\section{D7 Fly Ranch/Gerlach, Nevada}

The Fly Ranch/Gerlach area is in northwestern Nevada, 85 miles north of Reno and 80 miles west of Winnemucca. The general area is sometimes identified by other names: Ward Ranch, Hualapai Flat-Gerlach or Black Rock Desert. The prospect is located in Washoe and Pershing Counties. There are hot springs and two KGRAs have been defined: Fly Ranch containing 20,662 acres and Gerlach containing 8972 acres. The area is mapped in Figure $D-8$. This prospect ranks number nine in development potential.

Fly Ranch/Gerlach lies in a system of Basin and Range valleys that are bounded by normal faults extending northeastward into the Alvord Desert of Oregon. The northern (Fly Ranch) area contains one of the largest thermal systems in the region and shows evidence of current tectonic activity. The Fly Ranch hot springs lie in an area of Late Quaternary and Holocene faulting; the highest (over 20 feet) scarp in the area lies immediately east of the springs. The hot springs are located on a horst structure with a graben to the northwest. Further to the north, a system of rifts exists, the rifts ranging in length from a few tens of feet to over four miles and in width from fractions of an inch to over five feet. There is no dip-slip or strike-slip offsetting indicating that the area is in tectonic tension. The rifting is Holocene in age and some of the surfaces are uneroded indicating very recent activity.

Fourteen miles to the south, the Gerlach thermal area lies on the same north-northeast trending fault system as the Fly Ranch thermal area. The Gerlach hot springs are located on a major regional fault intersection: silica deposits from an old, dry spring exist near the town of Gerlach.

The highest observed spring temperature is somewhat over $220^{\circ} \mathrm{F}$, observed in Fly Geyser, a shallow boiling well. The highest chemical temperature is approximately $340^{\circ} \mathrm{F}$ at Gerlach Hot Springs. Two shallow wells, approximately 800 and 1000 feet in depth, were drilled at Fly Ranch by Western Geothermal Incorporated in 1964-65. No results have been reported. There is no reported drilling at Gerlach. 
The results of geophysical exploration in the Black Rock area by the Sun 0 il Company over the past decade have been made available to exploration specialists at the Colorado School of Mines, who have followed up with additional electrical and seismicity surveys. Results reported to date are highly preliminary although the seismic (microearthquake location) data shows anomalies that may correlate to geothermal accumulations (Refs. $D-22, D-23$ and $D-24)$.

The area is extremely isolated and sparsely populated. The population of Pershing County is 2670 and Gerlach, the nearest town, has 130 residents.

The area is rural with the few residents being employed in mining, agriculture and transportation. There is no public opposition to geothermal development; Washoe County officials are looking forward to development. Development could generate "boom and bust" economic conditions, however.

Land use is primarily grazing, farming, mineral production and recreation. The land is zoned for open use; the only zoning for specific use in Nevada is near Reno. 6751 acres within the Fly Ranch KGRA were recently leased.

The region is typical Basin and Range desert with broad valleys, playas, dry washes and mountains of moderate relief being characteristic. The landscape at the prospect is foothill/mountainous. Color and texture contrasts are interesting and the area is one of rough, rugged beauty. The alluvial basin contains groundwater of good quality; quality decreases toward the dry lakes. Streams are intermittant but there are several large reservoirs located on private land in the general region.

An Environmental Analysis Record of the area has been generated (Ref. D-25). Air quality has not been measured but particulate matter arising from dust storms is a continual problem. Noxious gases, emitted by vehicles and aircraft, have been found in small amounts. Ambient noise levels are low.

Dominant vegetation includes saltbush/greasewood, sage brush, shadscale and winterfat. 58 species of mammals, 115 species of birds, 5 of amphibians, 20 of reptiles and nine of fish have been recorded in the area; dominant species are mule deer, pronghorn antelope, sage grouse and cutthroat trout. 
Aquatic invertebrates and plants are found in the hot springs." Rare/ endangered species in the general region includes the Prairie Falcon, Desert Dace and Lahontan Cutthroat Trout.

Archeological and historical sites abound in the region but none has been found in the immediate vicinity of the prospect.

\section{3,3}




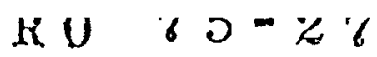

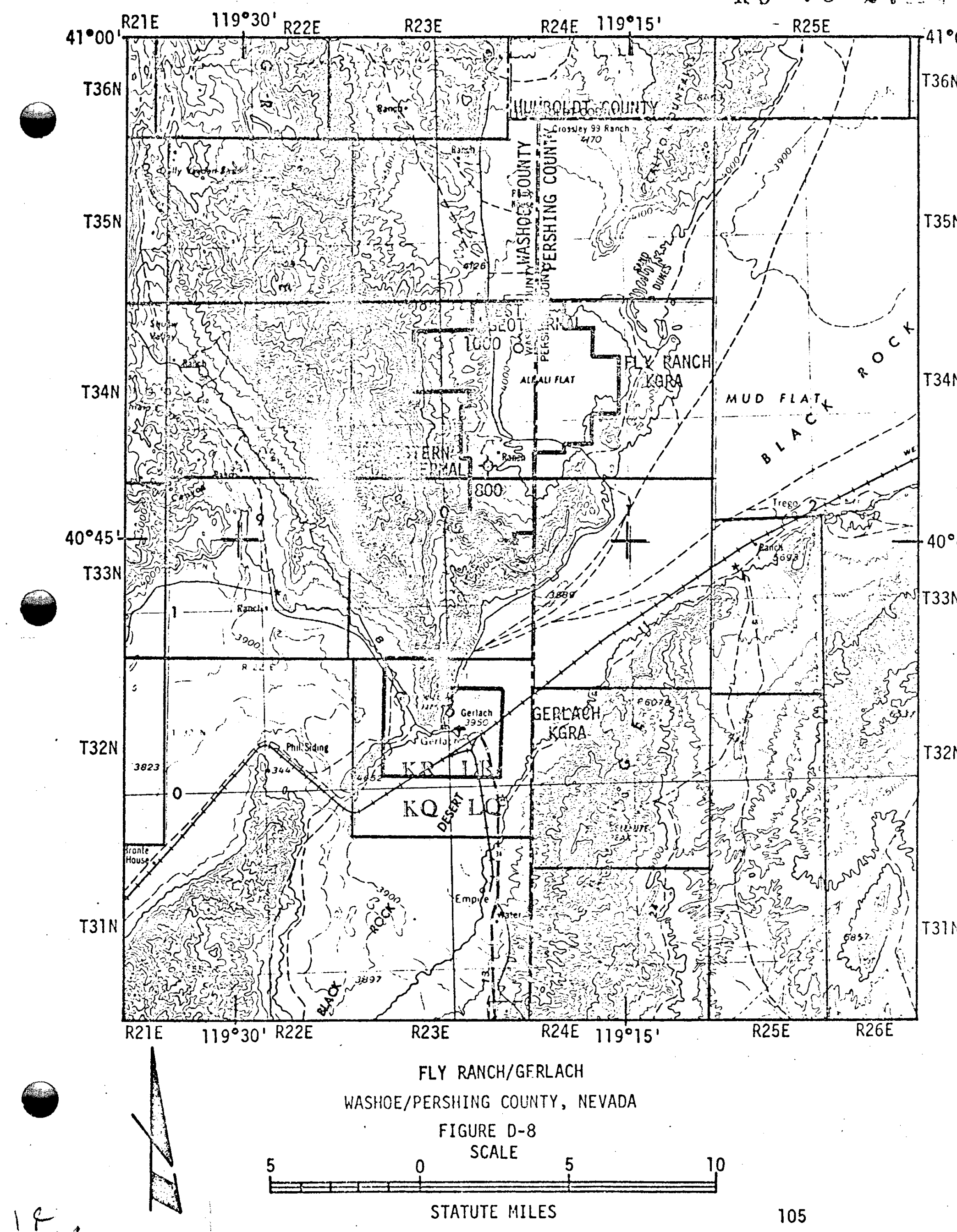


D8 Long Valley, California

The Long Valley area is located in east central California, east of the Sierra Nevada Range in Mono County. Hot springs exist and 460,256 acres, enconipassing both Long Valley and the Mono geothermal area to the north, have been classified as a KGRA. The area is mapped in Figure D-9. This prospect ranks number four in development potential.

Long Valley is a major, well-recognized collapse structure (caldera), approximately 10 miles wide (northeast-southwest) by 20 miles long. The collapse occurred perhaps 680,000 years ago and volcanism has continued to very recent times. The Inyo craters in the northwest corner of the area may be only 650 years old.

Thermal springs are plentiful. Fumaroles exist at Casa Diablo Hot Springs where flows of $35 \mathrm{GPM}$ at a maximum temperature of $194^{\circ} \mathrm{F}$ have been measured and at the Geyser where a flow of 500 GPM at temperatures exceeding $200^{\circ} \mathrm{F}$ has been noted. Analysis of spring and shallow well waters shows a general TDS content of 1-2,000 ppm and a silicate content of 1-300 ppm. The waters are, in general, rich in chloride (Refs. D-26 and D-27).

Approximately 20 shallow (1ess than 1000 feet deep) wells were drilled in the early sixties, primarily in the Casa Diablo area. Maximum temperatures of $350^{\circ} \mathrm{F}$ and maximum flow rates of $500 \mathrm{GPM}$ were encountered. The average TDS content was approximately $1500 \mathrm{ppm}$. The water contains problem amounts of arsenic and boron. Development was halted by the difficulties with disposal of the arsenic/boron-laden water and by the implementation of new environmental requirements.

Long Valley has been the scene of an intensive, comprehensive geotechnical investigation by the United States Geological Survey. Deep heat flow measurements have been made outside of the caldera with no anomalous results as near as 4 miles to the rim on the north, south and west. Excess heat is found approximately 2 miles to the west of the rim (Ref. D-28). Heat flow measurements obtained from shallow holes within the caldera show 
a variable pattern probably reflecting shallow water flow. In summary, the data available does not indicate a significant thermal anomaly and, if one exists, it is probably limited to the immediate vicinity of the caldera.

A series of electrical/electromagnetic surveys have been made (Refs. D-29, D-30 and D-31). A total-field resistivity survey has mapped structural features and hydrothermal alternation zones within the caldera and has related these to geothermal potential and past and present hydrothermal activity. Electrical and electromagnetic soundings located several shallow conductive bodies (that may be related to geothermal activity) and one deep conductive body. Reconnaissance audio-magnetotelluric soundings outlines two linear high conductivity zones that correlate closely to known hot springs. Self-potential anomalies have been attributed to horizontal ground-water flow patterns and vertically-flowing hot water.

Seismic noise and microearthquake studies have been made. A noise amplitude anomaly exists in the caldera but the microearthquake data shows a relatively constant, relatively minor level of seismicity. The seismic data does not appear to correlate directly with surface hydrothermal activity; interpretation is made difficult by reverberation within the caldera.

Gravity and magnetic anomalies are associated with Long Valley. The gravity data shows the caldera to have steep walls and to contain approximately 10,000 feet of fill. Local gravity and magnetic relief are indicative of relatively shallow masses existing within the fill.

The county population in 1960 was 2500 and is now estimated to be 7200 . The two nearest population centers, Mammoth City and Bishop, have 900 (5000 in winter season) and 3500 residents, respectively.

The Mono County economic base is the recreation industry. The economy is heavily tourist-related with some timbering, mining and agriculture. Future plans focus on increases in recreation and tourism with conservation and intelligent use of existing resources being a prime objective. Public reaction to geothermal development is generally negative at present although county officials are encouraging development for taxation purposes and because it is a good example of an optimum means of using a resource. 
Full development of the geothermal potential at Long Valley could have a significant effect on the Mammoth City economy and culture but might add 2.5 million dollars annually to the county tax base. Future plans will be altered somewhat to include geothermal activities.

There is a general plan for Mono County, currently in revision. Approximately $79 \%$ of the county lands are controlled by the Bureau of Land Management or the Forest Service; the remainder is privately-owned, primarily by the Los Angeles Department of Water and Power. County land use is primarily recreational. Potential geothermal land is zoned as "general purpose." A recent sale of leases in the KGRA brought a maximum bid of $\$ 291 /$ acre. A total of 5483 acres were leased.

The landscape at Long Valley is essentially flat; slopes range from zero to ten percent. The elevation is 7-8,000 feet (Ref. D-32). Crowley Lake and perhaps Mono Lake to the north offer potential sources of cooling water as do the Owens River and other permanent streams in the area.

Two Environmental Impact Statements of the area have been prepared (Ref. D-33). Air quality has been measured as has the ambient noise level. With regards to air quality, in each of three samples, the particulate content exceeded the standards of the State Air Resources Board. Further, from a three week sample, the oxidant content exceeded these same standards for 11 hours and the hydrocarbon content exceeded the standards for seven. days. The source of the particulates is unknown but motor vehicles generate the oxidants and hydrocarbons. The noise level, derived from trucks, may be as high as 90-95 dbA.

Plant life in Long Valley is of the Upper Sonoran zone type including sage, bitter and rabbit brush, pinon and juniper. Animal, life includes sage grouse, mule deer, black bear, pine martin, ground squirrel and owl. Hot creek is a "wild trout stream," harboring brown, rainbow and brook trout. Rare/endangered species in the general region are four plants, Bighorn Sheep, Wolverine, Spotted Bat, Bald Eagle, Owens Chub and Prairie and Peregrine Falcon. Of these, only the chub might be affected by geothermal development.

There are old Indian habitation sites including petroglyphs in the southern part of the valley. 


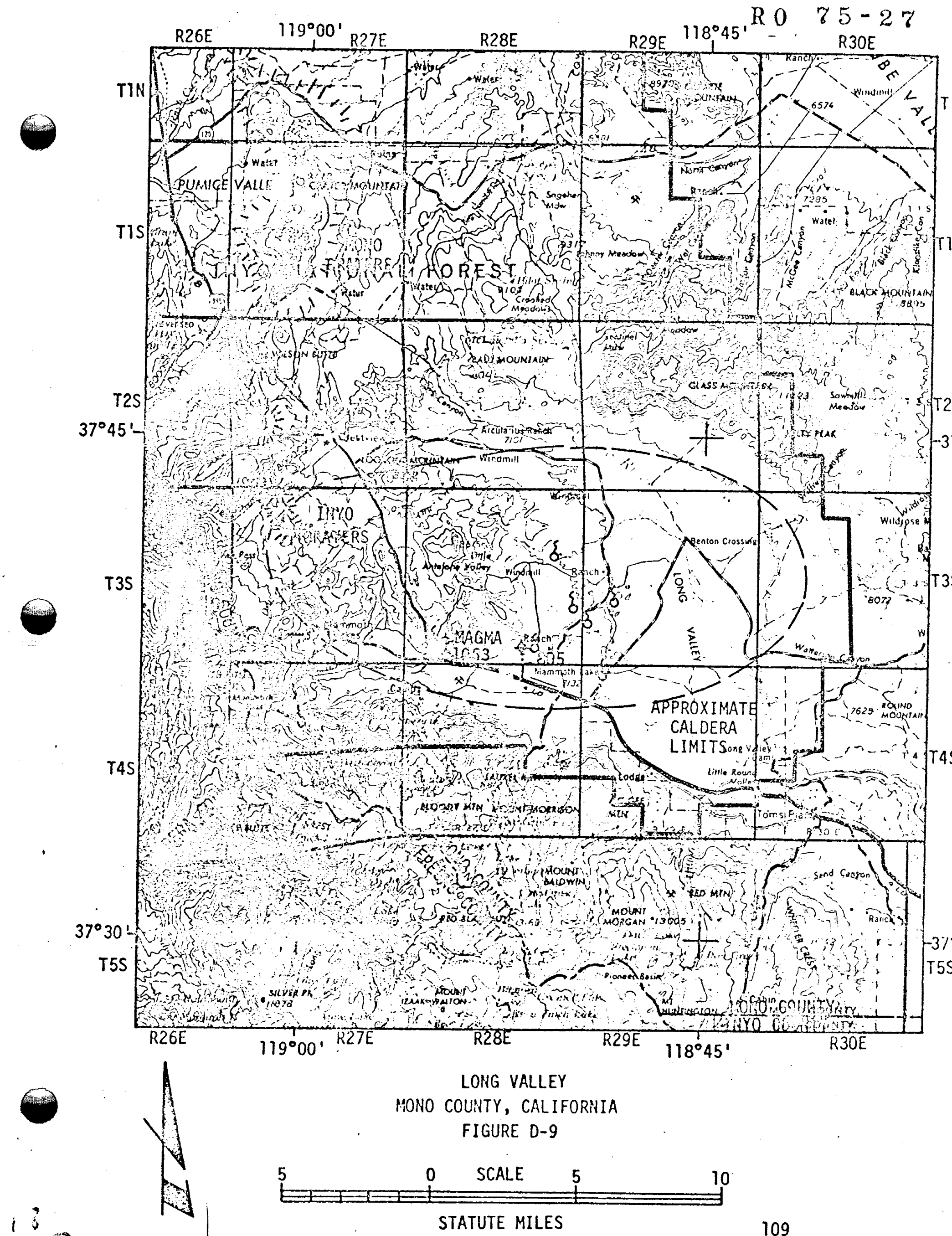




\section{D9 Mountain Home, Idaho}

The Mountain Hone area is located in south-central Idaho, approximately 50 miles southeast of Boise. Hot springs exist and 9520 acres have been classified as a KGRA. The area is mapped in Figure D-10. This prospect ranks number 10 in development potential.

The prospect lies in the zone between the central Idaho Tertiary and Cretaceous granitics and the Tertiary and Quarternary rock of the Snake River Plain to the west. To the northwest near Boise, the transition zone is relatively abrupt and marked by a series of northwest-southeast trending faults. Mountain Home lies on this fault trend and a series of subparallel faults have been mapped. These faults control the major thermal springs in the area.

Thermal waters are plentiful. A spring in the northeast part of the area delivers water at approximately $150^{\circ} \mathrm{F}$ and irrigation wells in the same area, 500 to 1000 feet deep, yield $135-155^{\circ} \mathrm{F}$ water. The water is fresh with a TDS content of about 300 ppm. (Ref. D-34)

The Gulf Energy and Mineral Company recently drilled a deep test in the area. The well was reportedly located in a fault zone by renote sensing techniques (nature unknown) with gravitational evidence of a shallow intrusive. The well was spudded in Pleistocene and the first basalt was encountered at 1180 feet. A section of clays, shales and detrital volcanic sands was found at 2160 feet and a thick (590 feet) basalt was encountered at 4160 feet. Below the basalt, 2370 feet of acidic volcanoclastics were peentrated. Andesite was found at 7120 feet, granite was reached at 9490 feet and the hole bottomed in granite at 9616 feet.

Temperatures in excess of $300^{\circ} \mathrm{F}$. were measured below 6500 feet. However, analys is of the geophysical logs indicates low porosity above approximately 8100 feet and high porosity, lacated in zones, below this depth. A bottom-hole temperature of $348^{\circ} \mathrm{F}$ was measured during logging and immediately after stopping circulation. Accordingly, this temperature may be low in that the cooling effects of circulation had probably not completely dissipated. 
This well initially flowed at approximately 1000 GPM but flow stopped within two weeks. The water is drinkable (TDS content of less than 800 $\mathrm{ppm})$ and the state has given permission to reinject this water into shallow acquifers. Water of this quality at the elevated temperatures indicates recharge by meteoric water and also probably indicates a circulation system of large extent in that the salts being dissolved from the subsurface are rapidly dispersed.

Elnore County now contains approximately 20,000 residents with no more than 50 people living within the KGRA. The area is rural and contains few settlements or services. The town of Mountain Home to the west has a population of 6500 .

Income is derived primarily from ranching, timbering and recreation and geothernal development could generate a "boom and bust" economic cycle. The county does not encourage energy development because the probable associated increase in industrialization is undesired. Public opposition to development can be expected.

There is no county general plan. Most private land is used for ranching and Federal and state lands are used for grazing and recreation. Geothermally-inieresting acreage is entirely on Federal (BLM) land. The county zones only incorporated private land. At a recent lease sale within the KGRA, no bids were received.

The region is characterized by narrow valleys and wide plains. The Mountain Home landscape appears as a sagebrush-covered expanse backed by timber-covered slopes. Much of the natural environment has been altered by grazing and culture in the form of roads, power lines and farm buildings is persistently present.

An Environmental Analysis Report on geothermal leasing and development in the Boise region has been prepared by BLM (Ref. D-35).

Many permanent streams exist although essentially all have been diverted for agricultural purposes. Ground water reserves are unknown but are thought to be small. Air quality is excellent and ambient noise is very low. Because of the excellent quality of the subsurface water and 
its suitability for drinking and the support of wildlife, this is a prospect when geothermal development may have a positive environmental effect.

Plant life is of the sagebrush-grass type. Dominant animal life include mule deer, elk, coyote, rabbit, mice, squirrel and many birds. Aquatic life abounds. The Prairie Falcon is the only rare/endangered species that is seen in the area.

The Oregon Trail and the Kelton Wagon Road passed through the general area and Shoshone artifacts and petroglyphs are found. 


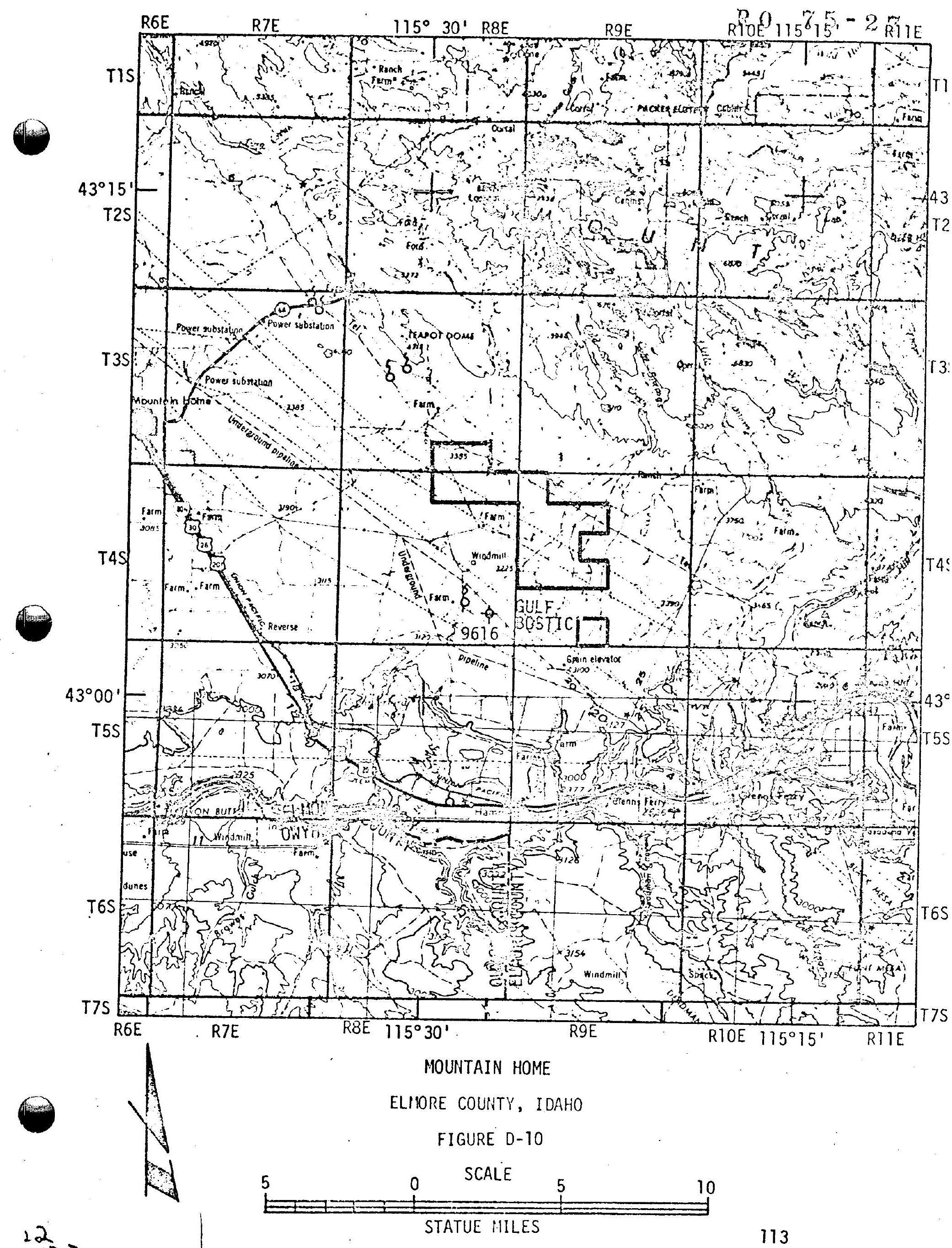


D10 Raft River, Idaho

The Raft River area is located in south-central Idaho, approximately 40 miles southeast of Burley. The area is in Cassia County. There are hot springs and 7680 acres have been classified as a KGRA. This KGRA is sometimes identified by the name "Frazier." The area is mapped on Figure D-11. This prospect is ranked number 11 in development potential.

The Raft River is a southern tributary of the Snake River and the Raft River Valley lies on the border between the Basin and Range geologic province to the south and the volcanic provinces to the northwest. The north-south elongate valley appears similar to other Basin and Range valleys. The valley is bounded on the west by Tertiary silicic volcanics traversed by north-trending major faulting, and this faulting appears to control thermal spring location.

The thermal area of interest lies in the southern part of the valley, a few miles north of the Utah state line. Two shallow wells have been delivering boiling water from a depth of about 400 feet for many years. One of these was flowing at 120 GPM in the early $1930 \mathrm{~s}$ and flowed 60 GPM in 1969. The other flowed at 26 GPM in 1961; water from this well has been used to heat a greenhouse. These wells produce from alluvium. 0ther shallow wells and springs in the area are cooler, maximum temperatures are below $100^{\circ} \mathrm{F}$.

The valley has been the scene of extensive geophysical work by the USGS. Chemical temperatures of $285^{\circ} \mathrm{F}$ to $320^{\circ} \mathrm{F}$ have been reported from the well water.

Recently, a coalition of ERDA, USGS, State of Idaho and the Raft River Electrical Cooperative drilled two deep geothermal tests in Sec. 23, T15S, R26E. These wells were located to intercept a fault zone at depth. By one interpretation by the operators, the first wel1 penetrated approximately 3800 feet of Tertiary section (sediments and tuffs), passed through the fault zone and penetrated Pre-Cambrian schists(?) and quartzites. Quartz monzonite basement was found at 4930 feet and the hole bottomed at 
5007 feet. The hole was cased to 3600 feet and produced 450-500 GPM of $297^{\circ} \mathrm{F}$ water from below the casing. Prior to casing, the well flowed at 6-700 GPM.

The second hole is located 700 feet northeast of the first. This well also penetrated Tertiary section and passed through the fault into the Pre-Cambrian Elba Quartzite at about 4800 feet. Basement was found at about 4900 feet and total. depth was reached at 6007 feet. This hole was cased to 4240 feet. $297^{\circ} \mathrm{F}$ water was produced from the $4200-5200$ foot zone at flows from 750 to 800 GPM.

Water quality is good (TDS < 2000). The indicated chemical temperature is $358^{\circ} \mathrm{F}$.

Cassia County now has approximately 20,000 residents, 8300 of whom are in Burley. Oakley, the nearest population center to the prospect, has 650 residents. The area is rural with some light industry focusing on potato processing. The general economy is based upon farming and ranching. The prospect area is almost exclusively agricultural with a population density of less than one person per square mile. There is no public opposition to geothermal development al though development could cause a "boom and bust" cycle.

There is no general plan for the county. The county is currently in reorganization and there is no planning department. No zoning has been done. Principal land uses are agriculture and grazing with some recreation.

The valley landscape is generally flat with small gullies and ridges. The natural environment has been altered extensively by farm activities. The area is not considered aes thetically extraordinary.

Many intermittent and permanent streams are in the valley. Shallow ground water has been used for irrigation for many years but, more recently, the valley has been closed to additional shallow drilling because of declining reservoir pressure.

An environmental report concerning the geothermal test wells is available (Ref. D-36) as well as an Environmental Analysis Record pertaining to geothermal leasing in the county. (Ref. D-37) 
Air quality is generally excellent al though wind-blown dust can often be a pollutant. Ambient noise is very low.

Vegetation in the valley is of the sage subclimax type with sagebrush, greasewood and juniper being dominant. The valley abounds in wildlife (rabbit, deer, coyote, squirre1s, snakes and many birds) and trout, suckers, and minnows are found in the streams. Rare/endangered species in the region consist of four birds: Greater Sandhill Crane, Prairie Falcon, Peregrine Falcon and Ferrigenous Hawk. The latter two nest in the area.

There are two historical sites in the valley, the City of Rocks Indian burial ground and a stagecoach station on the Kelton Road trail. 
Ro r $85-27$ R27E $113^{\circ} 15^{\prime}$ - R2BE

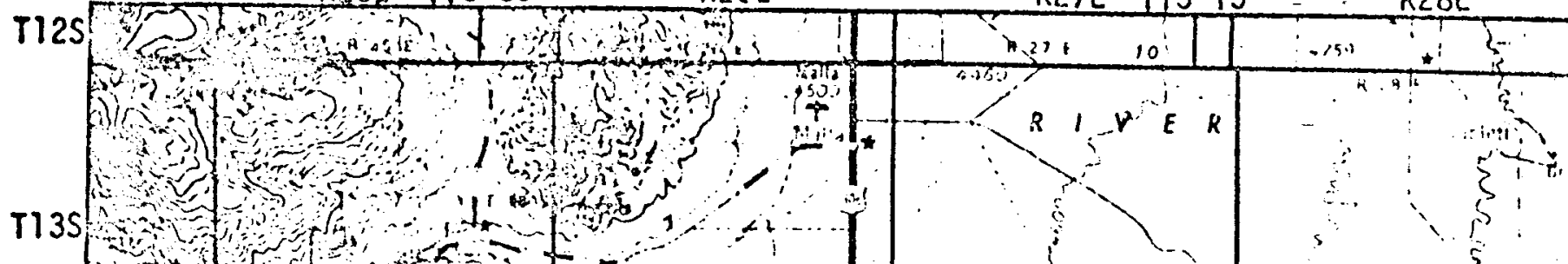

${ }_{42}^{\circ} 12^{1}$

T14S

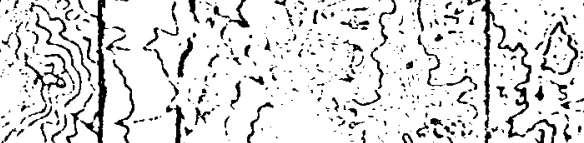

(1)
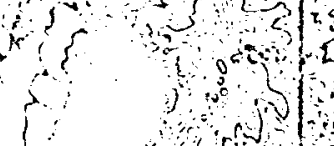

3

Tis
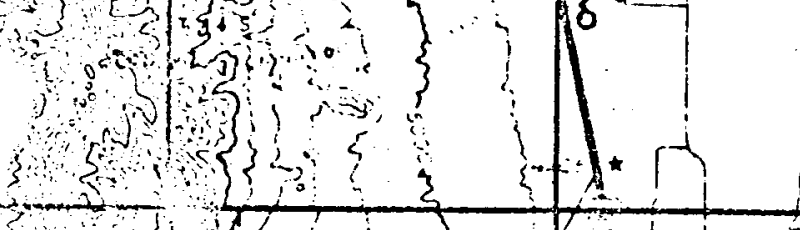

(1)

on

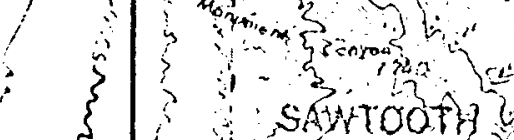

T14

T16S

T15s

(o) $)_{\text {tems }}=$ in

?)
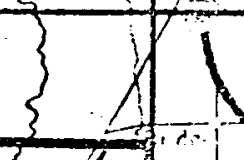

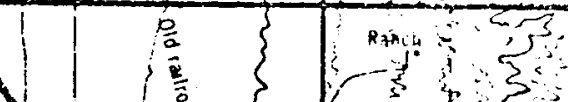

witorycosins
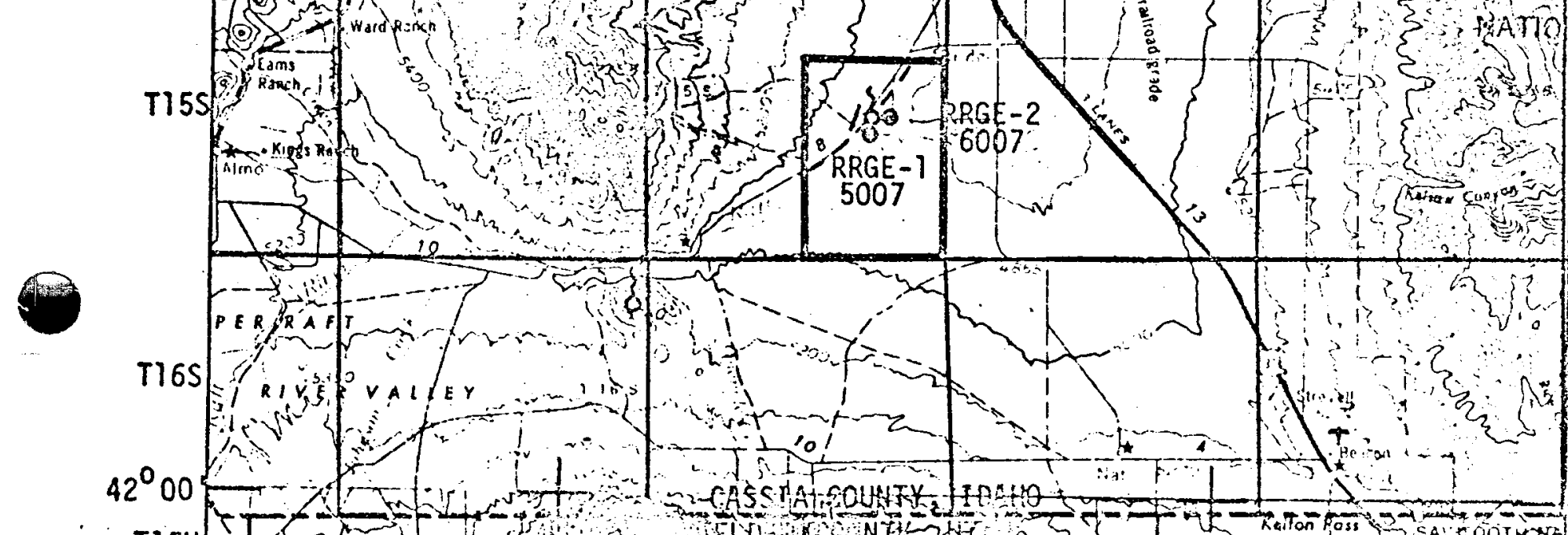

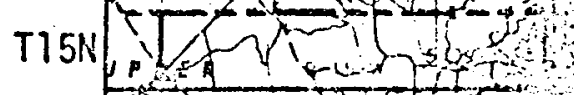

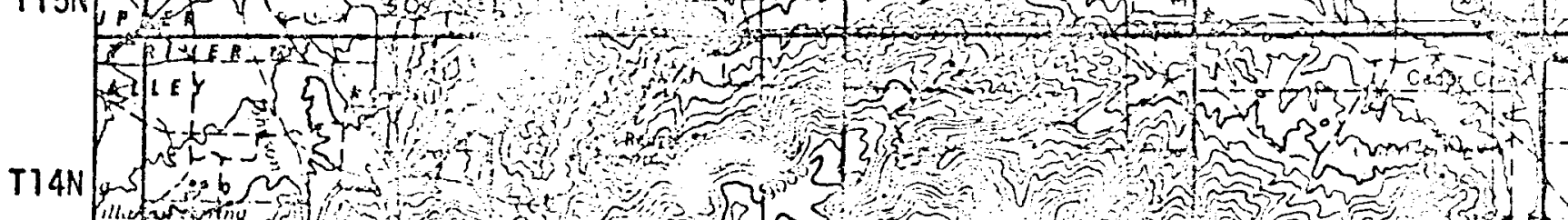

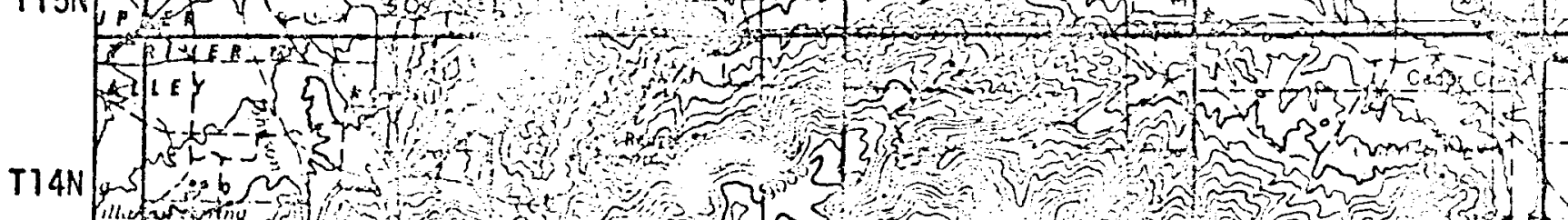
(x)
2.
m,
Hen

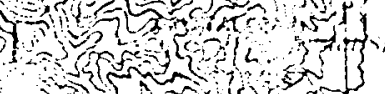

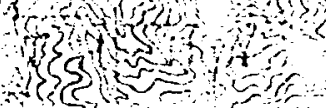

AT?

$=2$

3 sopin

$\frac{1}{3+1}$

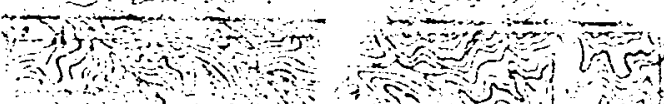

T13N

Art

3

$42^{\circ}$

T15

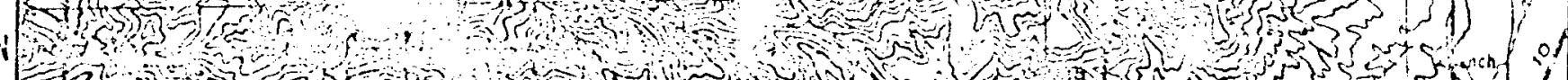

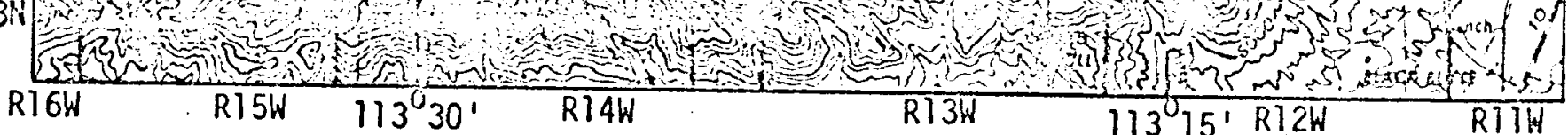
R73W $113^{\prime} 15^{\prime} \mathrm{R} 12 \mathrm{~W}$

RTIW

RAFT RIVER

CASSIA COUNTY, IDAHO

FIGURE D-11

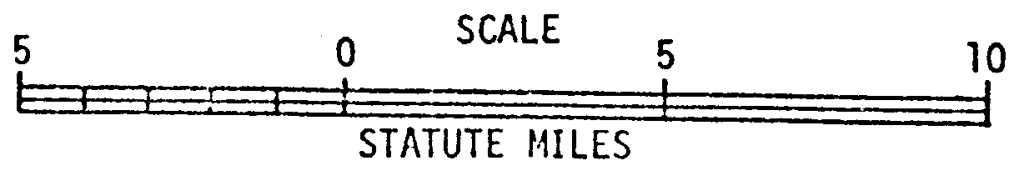




\section{D11 Rooseve1t, Utah}

The Roosevelt area is located in southwestern Utah, 12 miles northeast of Milford and 20 miles northwest of Beaver. The area is in Beaver county. Hot springs exist and 29,791 acres have been classified as a KGRA. The area is mapped on Figure D-12. This prospect ranks number one in development potential.

The thermal area lies in the Basin-and-Range province on the western flank of the Mineral Mountains. Tertiary and Quaternary unconsolidated sediments cover most of the area with Precambrian (?) metamorphics and Tertiary volcanics, and other rocks outcropping to the east. Hot spring activity appears to be controlled by the north-south trending Dome Fault and the area is marked by hot-water derived siliceous material that locally cements the alluvium.

The main spring was discharging approximately $10 \mathrm{GPM}$ at $190^{\circ} \mathrm{F}$ in 1908. Discharge decreased until the spring was dry in 1966. In 1957, analys is of the spring water showed a TDS of $7800 \mathrm{ppm}$ and a silica content of $313 \mathrm{ppm}$. The spring at one time served as a resort.

A shallow well was drilled in 1968, encountering steam at 60 feet. The well blew out at 275 feet and was controlled only with difficulty. Water temperatures in excess of $270^{\circ} \mathrm{F}$ were measured (Ref. D-38). The area is now the site of a deep geothermal test in Sec. 3, T27S, R9W by the Phillips Petroleum Company. The operator reports that the interval from 2700 to 2800 feet was tested with substantial shows. Initially, 200,000 $\mathrm{lb} / \mathrm{hr}$ of steam at $400^{\circ} \mathrm{F}$ was recovered, equivalent to a water flow rate of $400 \mathrm{GPM}$. The top of the altered volcanic pay zone is at 2724 feet. After a control valve was installed, a sustained hot water flow was obtained, indicating that the reservoir is probably water-dominated. Informal information indicates a temperature in excess of $400^{\circ} \mathrm{F}$; for reference purposes, nearly-saturated steam at a depth of 2800 feet implies a temperature in excess of $500^{\circ} \mathrm{F}$. There have been difficulties with the hole and the drilling of an offset well is imminent.

The area is the site of a comprehensive geological/geophysical investigation by the University of Utah. Preliminary results on electrical 
resistivity and electromagnetic soundings are available (Refs. D-39 and D-40). The resistivity data indicates three zones of interest, the dominant of which generally coincides with the Done Fault and thermal spring activity.

The area is sparsely populated. The present population of Beaver County is approximately 4000 with an increase to 5500 anticipated by the year 2000. The two nearest urban centers, Milford and Beaver, have populations of 1300 and 1500 respectively.

At present, government and trade employ the largest number of workers. Transportation, mining, agriculture and tourism also are important to the economy. Some mining-related industry exists at Milford. Mining, agriculture and tourism are expected to increase in the future but land utilization is not expected to deviate substantially from current usage. Local residents generally welcome the possibility of geothermal development as a potential boost to the county economy. A "boom and bust" cycle is a possibility, however.

A general plan governing land use exists (Ref. D-41). In Beaver County, land ownership is as follows:

$\begin{array}{lr}\text { Federal (BLM and National forest) } & 78.0 \% \\ \text { State } & 9.4 \% \\ \text { Private } & 12.6 \%\end{array}$

Most land is of multipurpose usage with private lands being used primarily for agriculture. The land presently proposed for geothermal usage is zoned so that use restrictions apply only to salvage yards, dumps and gravel pits.

A recent lease sale within the KGRA gained a maximum bid of $\$ 128 /$ acre, a very high figure for geothermal lands. In total, 23,392 acres were leased.

The Roosevelt thermal area has historically been used for grazing and mining and is relatively undeveloped. The general landscape is of the desert type. The mountainous, southeastern part of the area affords moderate to highly scenic areas. The natural environment has been altered by grazing and cultural features such as mines, roads and fences. 
Streams in the area are intermittent. One permanent stream flows through the southeastern part of the area. There are no other surface waters in the immediate area. Cooling water will probably not be available in that the only potential source would be shallow subsurface aquifers. However, shallow groundwater has been used for irrigation in the Milford area for some time and this has led to up to six feet of surface subsidence, the only instance of subsidence caused by groundwater withdrawal in the state of Utah. (Kef. D-42)

The thermal area is not inhabited at present but is visible from State Highway No. 257. This road, however, does not carry heavy traffic loads and the ambient noise level is minimal. No air quality measurements have been made; however, the air is relatively free of pollutants except dust.

An Environmental Analysis Report has been prepared on the Roosevelt area (Ref. D-43)

Four vegetation associations are found in the vicinity of the thermal area. These are:

- Desert scrub (shadscale, greasewood)

- Sagebrush (great basin sage, cheat grass, halogeton)

- Pinon-juniper (rabbit brush, bluebunch, wheat grass)

- Pinon-juniper pine (ponderosa pine, mountain mahogany).

Many animals roam the general area, the dominant being mule deer, bobcat, coyote, golden and bald eagle and Great Basin rattlesnake. The only rare or endangered species that may use the area are Prairie and Peregrine Falcons but no nesting sites are known. There are no aquatic plants and the only known aquatic animal is the Great Basin Spadefoot Toad.

Twelve historic and pre-historic inhabited sites are known in the area. One of these is a chipping area with an associated Clovis fluted projectile point that is regarded as one of the most significant archeological finds in the state of Utah. Increased activity could pose a threat to archeological values. 
D12 Steamboat Springs, Nevada

The Steamboat Springs area is located in west-central Nevada, 12 miles south of Reno and seven miles northwest of the Virginia City mining area. The area is in Washoe County. Approximately 50 hot springs are found and 8914 acres have been classified as a KGRA. The area is mapped on Figure D-13. This prospect ranks number six in development potential.

The thermal area is in the northeastern portion of the Steamboat Hills. These hills are a basenent uplift lying in a north-trending structural trough between the Carson Range to the west and the Virginia Range to the east. The trough floor is comprised of alluvium and recent surficial deposits. Quaternary volcanics cover part of Steamboat Hills. Three and possibly five Pleistocene or Holocene volcanic domes were extruded in the area; formation of these domes may be contemporaneous with formation of the Mono Craters in the Long Valley/Mono area to the southeast.

The Virginia City mining district, of which this prospect is a part, is the site of extensive, hydrothermal ore deposition and the Steamboat Springs sys.tem has been much studied (Ref. D-44).

The hot springs lie on a terrace of silicious sinter. Most of the sinter deposits trend northward and are broken into long fissures and small crack networks. Hot spring location, and sinter deposition, is controlled by an underlying fault zone that trends northeast. The oldest sinter deposit is middle or late Pleistocene.

Surface temperature of the spring waters ranges from $85^{\circ} \mathrm{F}$ to $206^{\circ} \mathrm{F}$. The water is of generally good quality having a TDS content of approximately $2500 \mathrm{ppm}$ (Ref. D-45). Study of the natural spring system shows clearly that essentially all the spring water is of meteoric (surface) origin, and that surface conditions of pressure and water saturation after rainfall have large effects on the natural discharge, which is estimated at about 1100 GPM in total.

In addition to several older shallow wells, there are at Steamboat Springs six geothermal wells drilled by Nevada Thermal Power Company between 1954 and 1961, ranging in depth from 520 to 1830 feet, and eight diamond- 
drill holes shallower than 1000 feet drilled by the USGS. Typically, the temperature profile in these wells is relatively constant at $340-355^{\circ} \mathrm{F}$ at depths below 500'. The Steamboat Springs \#4 wel1, 725' deep; recorded a maximum temperature of about $365^{\circ} \mathrm{F}$. It flowed more than $200 \mathrm{GPM}$ for over two weeks, and afterwards declined, probably due both to decline of pressure and deposition of calcite. Geochemical temperature estimates range from 355 to $405^{\circ} \mathrm{F}$.

Steamboat Springs lies in a relatively heavily populated area. The Reno metropolitan area had 120,000 residents in 1970 and population is increasing; an increase of $43 \%$ has occurred since 1960.

The general region is rural and supports small towns and settlements (Reno being the exception). Employment is concentrated in trade, services, agriculture, mining and tourism. Public opinion on geothermal development is mixed. Negative reactions are based upon the possible diverting of recreational land to industrial uses and an unwanted possible growth in the community.

Land ownership in Washoe County is primarily Federal al though most of the Steamboat Springs prospect is on private land. Land use revolves around agriculture and mining although recreational uses are becoming increasingly important. Steamboat springs has been used as a resort for many years. No data on zoning is available. Zoning for specific purposes is common in the Reno area and there are unofficial reports of residential zoning on the prospect.

The general area is Basin and Range-type topography. The specific area is mountainous but is laden with man-made intrusions. Hills are covered with numerous roads, power lines and other construction. The activity here is in marked contrast to the general serenity of the province.

Precipitation is rare on the valley floors. The Truckee River and Galena Creek are permanent streams in the area and Washoe Lake lies to the south. Groundwater may be of relatively poor quality. Air quality in the general area is quite good although particulate matter (dust) is generated by winds over the farmland and the natural landscape. Automobile-derived pollution can be severe in the Reno area. The ambient noise level at Steamboat Springs is apt to be relatively high. 
There is an Environmental Analysis Record of the general area (Ref. D-46). Several vegetative communities exist: cropland, riparian, desert scrub, pinon-juniper, grassland and conifer. Most plants in the prospect area are drought-resistant with saltbush, greasewood, and shadscale predominating. There are 79 species of mammals in the general area, over 250 species of birds and numerous species of rodents. There are also 32 reptile and amphibian species and 28 species of fish; no fish have been reported in the water at Steamboat Springs. Numerous rare/endangered species inhabit the region including the Peregrine and Prairie Falcon, White-faced Itis, Ferruginous Hawk, Osprey, and Spotted Bat; none of these have been reported to inhabit the immediate Steamboat Springs area, however.

There are numerous historical and archeological sites, including petroglyphs and open aboriginal camps, in the general area. Steamboat Springs is itself a historical site. Given the impending residential development of the area, the possibility of geothermal activities adversely affecting these sites appears remote. 


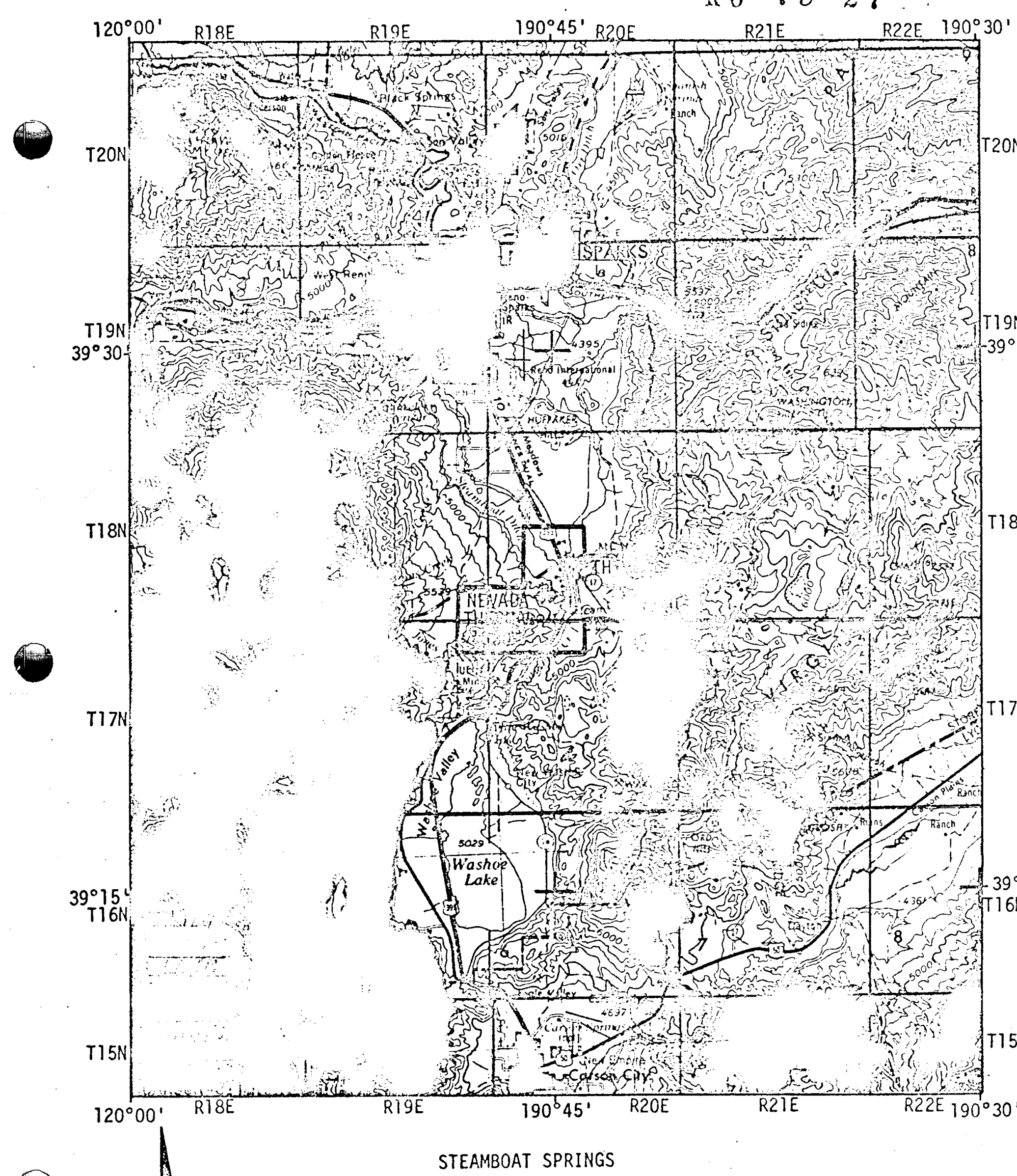




\section{D13 Surprise Valley, California}

The Surprise Valley area is located in the extreme northeast corner of California in Modoc County. Hot springs exist and 72,252 acres have been classified as the Lake City-Surprise Valley KGRA. The area is mapped in Figure D-14. This prospect ranks number eight in development potential.

Surprise Valley trends north-south and is approximately 55 miles long and an average of 8 miles wide. Geologicalily, it is a down-dropped fault block (graben) with up-lifted fault blocks (horsts) forming the mountain ranges to the east and west. Structure such as this is typical of the Basin and Range province to the east; however, the sedimentary and volcanic stratigraphic section is typical of the Modoc Plateau to the west. Surprise Valley, then, lies in a transition zone between provinces.

The Surprise Valley fault is a major structural feature paralleling the western side of the valley (Ref. D-47). The vertical displacement of this. fault may be as much as 12,000 feet, and the valley fill is at least 7000 feet in thickness. The lack of erosion on the fault scarp and the existence of uneroded landslide scars suggest recent (perhaps within 10,000 years) major movement. Seasonal saline lakes exist on the valley floors; several become dry in the summer months. Some of the more prominent lakes were formed by landslide-formed dams.

There are eight general areas of hot spring activity in the valley, six of which are in the northern portion. Water flows range from a few to many tens of GPM at maximum temperatures of $100^{\circ} \mathrm{F}$ to in excess of $200^{\circ} \mathrm{F}$. The waters are rich in sulfate, boron, fluoride and sodium and, in some cases, arsenic. A mud volcano erupted violently in 1951 (Ref. D-48).

Hot spring occurrence is structurally controlled with many found along the Surprise valley fault zone. Further, hot spring occurrence appears to be generally associated with young rhyolite flows and plugs that are found in the northern half of the valley (Ref. D-49).

Several shallow wells have been drilled in the valley, the highest temperature encountered being $320^{\circ} \mathrm{F}$. Three wells have been drilled in the area by Gulf $0 i 1$ Company. Two of these are in an area that the operator still considers to be a viable prospect and only the total depths 
(6841 feet and 5404 feet) have been released. The prospect is waterdominated. The third well, the ATR-Gulf Goodwin well, is located to the south, out of the prospect area. The well bottomed at 7005 feet and a bottom hole temperature of $240^{\circ} \mathrm{F}$ after seven hours was measured. The operator reports that all three wells penetrated only lake sediments.

The prospect population of Modoc County is 8400 ; population has been decreasing for the past 15 years. Surprise valley is isolated; the two nearest urban centers, Cedarville within the valley and Alturas, 25 miles to the west, have respective populations of 800 and 2800 .

Ranching and agriculture are the economic bases of the area with some tourism, manufacturing and mining. Significant changes in the county economic pattern have occurred recently with the construction of an interstate highway. A "boom and bust" cycle could be generated in Surprise Valley by introducing geothermal development. Public opinion on geothermal is mixed but no significant opposition is expected.

A general plan for Modoc County exists (Ref. D-50). $70 \%$ of the county land is Federally-owned, mostly by the Forest Service with the Bureau of Land Management also possessing significant quantities. $25 \%$ is privatelyowned and the state owns 5\%. Most public land is used for grazing, and lumbering is the primary use of the private land. Land within Surprise valley is principally grazing and farmland. Much of the promising geothermal areas lie on Federal acreage zoned for agriculture. 10,583 acres within the KGRA were recently leased.

The landscape within Surprise Valley is relatively flat and unobstructed. There are many irrigated farms. The area is not of high aesthetic quality; much of the natural environment has been altered by agricultural activities.

Water is a primary limited natural resource in the county. Three lakes exist in Surprise Valley; these are alkaline and of poor water quality. Wildlife and waterfowl use these extensively. Air quality is very good. Ambient noise data are not available.

An Environmental Impact Report pertaining to geothermal exploration is available (Ref. D-51) 
Vegetation is of the northern desert scrub type including sagebrush, bitterbush, juniper and various grasses. Vegetation in Surprise valley is low and sparse. Wildlife includes deer, antelope, rabbit and birds (dove, quale, pheasant, grouse, duck and eagle). Aquatic life distribution is not known. Rare/endangered species in the area include 8 plants, 2 fish (Shortnose and Modoc Suckers) and 4 birds (Bald Eagle, Osprey, Peregrine and Prairie Falcons).

Little is known of archeological sites in Surprise Valley. Several historical sites (Fort Bidwell, the Applegate Trail) exist. 


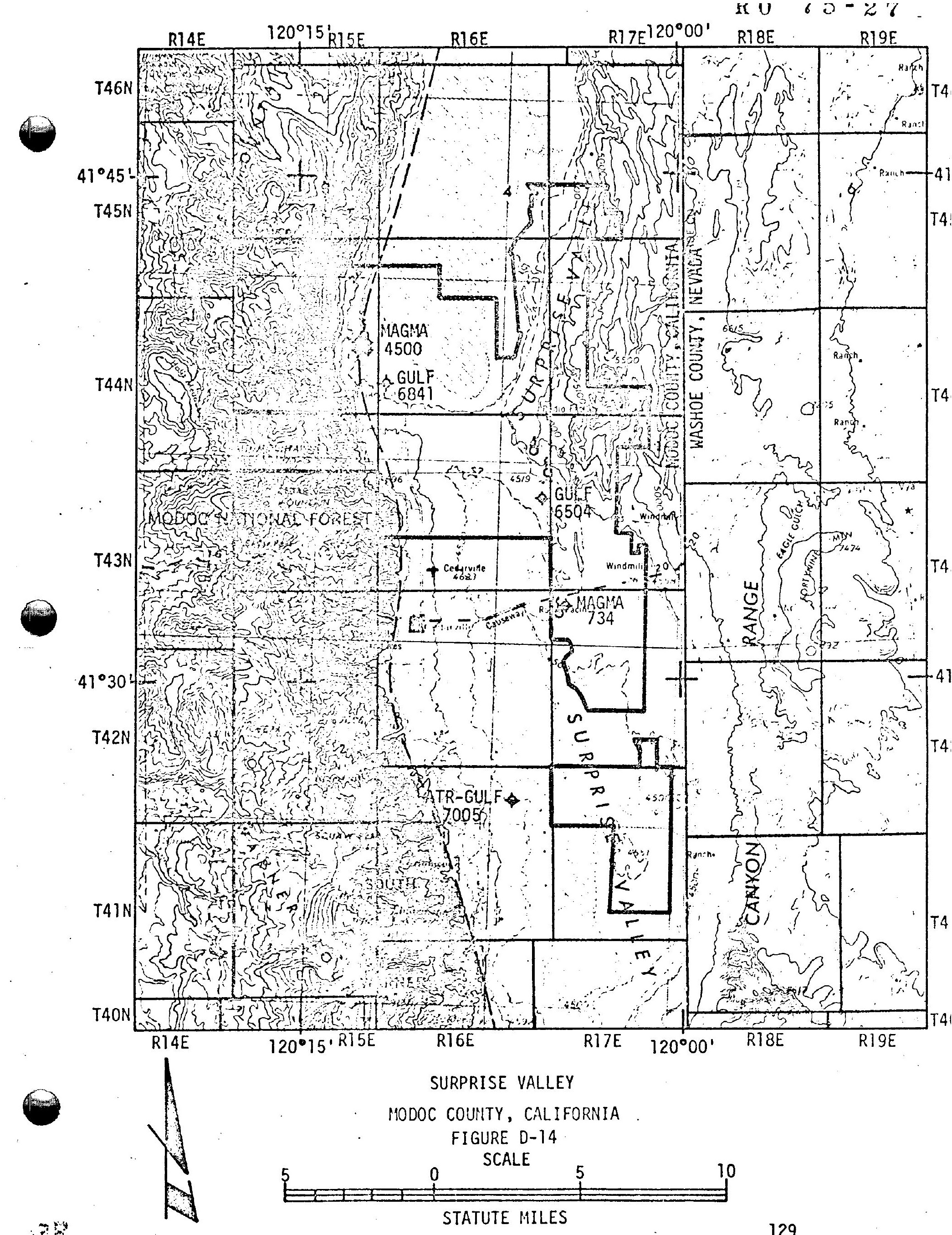




\section{APPENDIX D REFERENCES}

D-1 Hose, R.K. and Taylor, B.E.: Geothermal Systems in Northern Nevada; United States Geological Survey Open File Report 74-271, 1974.

D-2 Garside, L.J.: Geothermal Exploration and Development in Nevada through 1973; Nevada Bureau of Mines and Geology Report 21, 1974.

D-3 U.S. Department of Interior, Bureau of Land Management: Regional Environmental Analysis on Geothermal Leasing in the Shoshone Resource Area, Battle Mountain District, Battle Mountain, Nevada, 1974.

D-4 U.S. Department of Interior: Threatened Wildlife of the United States; Bureau of Sport Fisheries and Wildlife Resource Publication 114, 1973

D-5 Jim Brockett Associates A.I.P.: Churchill County General Plan 19721992, Churchill County Planning Department, Nevada, 1972.

D-6 U.S. Department of Interior, Bureau of Land Management: Environmental Analys is on the Proposal to Lease Federally Owned Potential Geothermal Resources in the Brady's Hot Springs and Fireball Valley Hydrographic Areas, Winnemucca District BLM Office, 1974.

D-7 Mundorff, J.C.: Major Thermal Springs. of Utah; Utah Geological and Mineralogical Survey Water Resources Bulletin 13, 1970.

D-8 Heylmun, E.B.: Geothermal Power Potential in Utah; Utah Geological and Mineralogical Survey Special Studies 14, 1966.

D-9 Maricopa County Planning and Zoning Department: Population Growth, Composition and Projections - Maricopa County, Phoenix, Arizona, 1972.

D-10. County of Maricopa, Arizona: Zoning Map of Chandler City and Surrounding Area, Map Sheet 0, B10, B29; 1975.

D-11 Chapman, R.H.: Geophysical Study of the Clear Lake Region, California; California Division of Mines and Geology Special Report 116, 1975.

D-12 Hahn, Wise and Associates, Inc.: Lake County General Plan; Lake County Planning Department, California, 1968. 
D-13 Signal $0 i 1$ and Gas Company: A Draft Environmental Impact Statement for Proposed Geothermal Resource Exploration and Development Diamond "D" Ranch Property, Lake County, California; 1973.

D-14 California State Lands Commission: Environmental Impact Report Geothermal Prospecting Permit, Lake County, California

D-15 ENVIROS: Draft Environmental Impact Report - Burmah $0 i 1$ and Gas Company, Castle Rock Springs Geothermal Steam Field Expansion, Dillingham Property, Lake County, California; 1974.

D-16 California State Fish and Game Commission: At the Crossroads 1974; Department of Fish and Game, Sacramento, California, 1974.

D-17 Duffield, W.A.: Late Cenezoic Ring Faulting and Volcanism in the Coso Range of Cal ifornia; Geology, 1975.

D-18 Leonard, G.W.: Total Energy Community; The Military Engineer, No. 434.

D-19 Austin, C.F. and Pringle, J.K.: Geologic Investigations at the Coso Thermal Area; Naval Weapons Center Technical Paper 4878, 1970.

D-20. Combs, J.: Heat Flow Studies, Coso Geothermal Area, China Lake, California; Technical Report No. 2.

D-21 Inyo County Planning Department: 1990 General Plan for Development of Inyo County, California; 1968.

D-22 Grose, L.T. and Keller, G.V.: The Colorado School of Mines Nevada Geothermal Study, Progress Report. No. 3; 1975.

D-23 Grose, L.T. and Keller, G.V.: The Colorado School of Mines Nevada Geothermal Study, Progress Report; 1974.

D-24 Micro Geophysics Corporation: Seismicity Report on Black Rock Desert Project Northwest Nevada; 1974.

D-25 U.S. Department of Interior, Bureau of Land Management: Environmental Analys is Record, $0 i 1$ and Gas/Geothermal Leasing, Winnemucca District, Sonoma-Gerlach Resource Area, Buffalo Hills Planning Unit; EAR No. 27-020-49-99, 1975.

D-26 Lewis, R.E.: Data on Wells, Springs, and Thermal Springs in Long Valley, Mono County, Cal ifornia; United States Geological Survey Open File Report, 1974.

D-27 Willey, L.M., O'Neill, J.R., and Rapp, J.B.: Chemistry of Thermal Waters in Long Valley, Mono County, California; United States Geological Survey Open File Report, 1974. 
D-28 Sass, J.H., Lachenbruch, A.H., and Munroe, R. J.: Thermal Data From Heat Flow Test Wells near Long Valley, California; United States Geological Survey Open File Report, 1974.

D-29 Stanley, W.D., Jackson, D.B., and Zahdy, A.A.R.: Preliminary Results of Deep Electrical Studies in the Long Valley Caldera, Mono and Inyo Counties, California; United States Geological Survey Open File Report, 1973.

D-30 Hoover, D.B., Frischknecht; F.C., and Tippens, C.L.: Evaluation of Audio-magnetotelluric Techniques as a Reconnaissance Exploration Tool in Long Valley, Mono and Inyo Counties, California; United States Geological Survey Open File Report, 1973.

D-31 Anderson, L.A., and Johnson, G.R.: A Self-Potential Survey of Long Valley Caldera, Mono County, California; United States Geological Survey Open File Report, 1974.

D-32 MONOPLAN Associates: Phase 2, Environmental Background Reports Monoplan for Mammoth; Mono County Planning Department,

- California, 1973.

D-33 SWR, Inc.: Draft Environmental Impact Report for MONOPLAN for Mammoth, California; 1975.

D-34 Ross, S.H.: Geothermal Potential of Idaho; Idaho Bureau of Mines and Geology Pamphlet 150, 1971.

D-35 U.S. Department of Interior, Bureau of Land Management: Environmental Analysis Record - Geothermal Leasing and Development of Potential Areas Within the Boise District - Bruneau, Grand View and Bennett Mountain.

D-36 Specer, S.G.: Environmental Report - Deep Geothermal Test Wells in the Raft River Valley; Aerojet Nuclear Company, Idaho National Engineering Laboratory, 1975.

D-37 U.S. Department of the Interior, Bureau of Land Management: Environmental Analysis Record - Geothermal Leasing on National Resource Lands in Cassia County, Idaho; Burley BLM District Office, 1974.

D-38 Petersen, C.A.: Roosevelt and Thermo Hot Springs, Beaver County, Utah; Utah Geological Association Publication 3; 1973.

D-39 Petrick, W.R.: Test Electromagnetic Soundings Roosevelt Hot Springs KGRA; National Science Foundation Technical Report 74-1. 
D-40 Ward, S.H., and Crebs, T.: Report on Preliminary Resistivity Survey, Roosevelt Hot Springs KGRA; National Science Foundation Technical Report 75-1.

D-41 Mountain Area Planners: A Master Plan for Beaver County and Municipalities, 1990; 1972.

D-42 Mower, R.W., and Cordova, R.M.: Groundwater in the Millard Area, Utah; Utah Geological Association Publication 3, 1973.

D-43 United States Department of Interior, Bureau of Land Management: Environmental Analysis Report - Exploration and Development of Geothermal Resources on National Resource Lands in the Vicinity of Roosevelt Hot Springs, Beaver and Millard Counties, Utah, 1975.

D-44 White, D.E.: Hydrology, Activity and Heat Flow of the Steamboat Springs Thermal System, Washoe County, Nevada; United States Geological Survey Professicnal Paper 458-C, 1968.

D-45 Brannock, W.W., Fix, P.E., Gianella, V.P., and White, D.E.: Preliminary Geochemical Results at Steamboat Springs, Nevada; Transactions, American Geophysical Union, Vol. 29, No. 2, Apri1, 1948.

D-46 U.S. Department of Interior, Bureau of Land Management: Draft Regional Environmental Analysis Record, Geothermal/0il and Gas Leasing, Pyramid Area, Carson City District, Nevada.

D-47 Slosson, J.E.: Surprise Valley Fault, California; Geology, December 1974.

D-48 Woods, M.C.: Geothermal Activity in Surprise Valley, California; Geology, December 1974.

D-49 Duffield, W.A., and Fournier, R.0.: Reconnaissance Study of the Geothermal Resources of Modoc County, California; United States Geological Survey Open File Report, 1974.

D-50 Modoc County Planning Department: Modoc County General Plan Natural Resource Elements, Modoc County, California; Adopted May 1974.

D-51 California State Lands Commission: Environmental Impact Report, Gulf 0il Company, 1974 . 